\title{
Water-Quality Assessment of the South Platte River Basin, Colorado, Nebraska, and Wyoming-Environmental Setting and Water Quality of Fixed Sites, 1993-95
}

By David W. Litke and Robert A. Kimbrough

U.S. GEOLOGICAL SURVEY

Water-Resources Investigations Report 97-4220 


\title{
U.S. DEPARTMENT OF THE INTERIOR BRUCE BABBITT, Secretary
}

\author{
U.S. GEOLOGICAL SURVEY \\ Thomas J. Casadevall, Acting Director
}

The use of firm, trade, and brand names in this report is for identification purposes only and does not constitute endorsement by the U.S. Geological Survey.

For additional information write to:

District Chief

U.S. Geological Survey

Box 25046, Mail Stop 415

Denver Federal Center

Denver, CO 80225-0046
Copies of this report can be purchased from:

U.S. Geological Survey

Information Services

Box 25286

Federal Center

Denver, CO 80225 


\section{FOREWORD}

The mission of the U.S. Geological Survey (USGS) is to assess the quantity and quality of the earth resources of the Nation and to provide information that will assist resource managers and policymakers at Federal, State, and local levels in making sound decisions. Assessment of water-quality conditions and trends is an important part of this overall mission.

One of the greatest challenges faced by water-resources scientists is acquiring reliable information that will guide the use and protection of the Nation's water resources. That challenge is being addressed by Federal, State, interstate, and local water-resource agencies and by many academic institutions. These organizations are collecting water-quality data for a host of purposes that include: compliance with permits and water-supply standards; development of remediation plans for a specific contamination problem; operational decisions on industrial, wastewater, or water-supply facilities; and research on factors that affect water quality. An additional need for water-quality information is to provide a basis on which regional- and national-level policy decisions can be based. Wise decisions must be based on sound information. As a society we need to know whether certain types of waterquality problems are isolated or ubiquitous, whether there are significant differences in conditions among regions, whether the conditions are changing over time, and why these conditions change from place to place and over time. The information can be used to help determine the efficacy of existing water-quality policies and to help analysts determine the need for and likely consequences of new policies.

To address these needs, the Congress appropriated funds in 1986 for the USGS to begin a pilot program in seven project areas to develop and refine the National Water-Quality Assessment (NAWQA) Program. In 1991, the USGS began full implementation of the program. The NAWQA Program builds upon an existing base of waterquality studies of the USGS, as well as those of other Federal, State, and local agencies. The objectives of the NAWQA Program are to:

- Describe current water-quality conditions for a large part of the Nation's freshwater streams, rivers, and aquifers.

- Describe how water quality is changing over time.

- Improve understanding of the primary natural and human factors that affect water-quality conditions.

This information will help support the development and evaluation of management, regulatory, and monitoring decisions by other Federal, State, and local agencies to protect, use, and enhance water resources.

The goals of the NAWQA Program are being achieved through ongoing and proposed investigations of 59 of the Nation's most important river basins and aquifer systems, which are referred to as study units. These study units are distributed throughout the Nation and cover a diversity of hydrogeologic settings. More than two-thirds of the Nation's freshwater use occurs within the 59 study units and more than two-thirds of the people served by public water-supply systems live within their boundaries.

National synthesis of data analysis, based on aggregation of comparable information obtained from the study units, is a major component of the program. This effort focuses on selected water-quality topics using nationally consistent information. Comparative studies will explain differences and similarities in observed water-quality conditions among study areas and will identify changes and trends and their causes. The first topics addressed by the national synthesis are pesticides, nutrients, volatile organic compounds, and aquatic biology. Discussions on these and other water-quality topics will be published in periodic summaries of the quality of the Nation's ground and surface water as the information becomes available.

This report is an element of the comprehensive body of information developed as part of the NAWQA Program. The program depends heavily on the advice, cooperation, and information from many Federal, State, interstate, Tribal, and local agencies and the public. The assistance and suggestions of all are greatly appreciated.

Robert M. Hirsch

Chief Hydrologist 
IV 


\section{CONTENTS}

Foreword

Abstract

Introduction

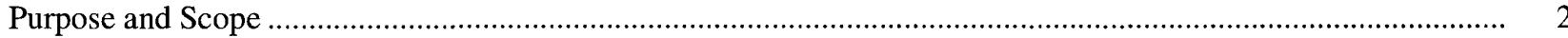

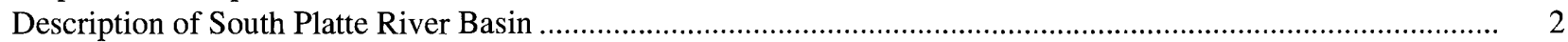

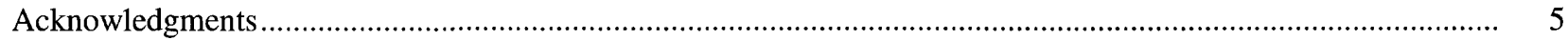

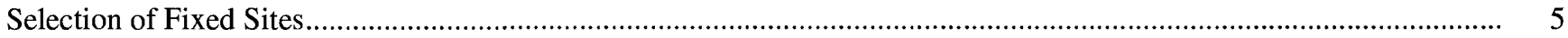

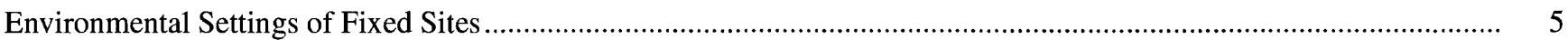

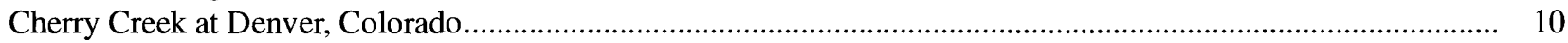

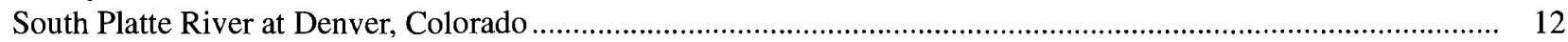

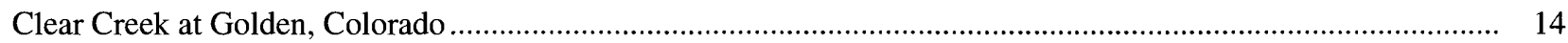

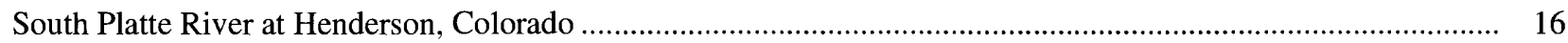

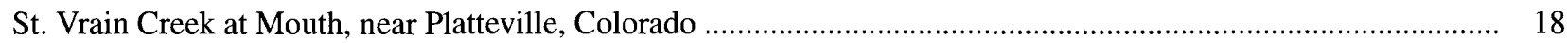

Big Thompson River below Moraine Park, near Estes Park, Colorado ............................................................. 20

Cache la Poudre River at Mouth of Canyon, near Fort Collins, Colorado .............................................................. 22

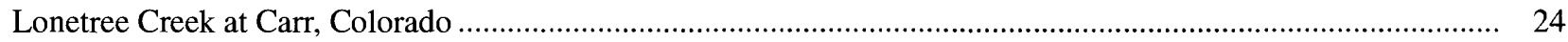

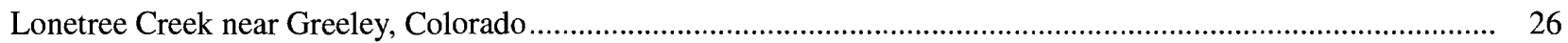

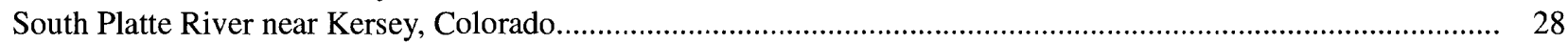

South Platte River at Cooper Bridge, near Balzac, Colorado ......................................................................... 30

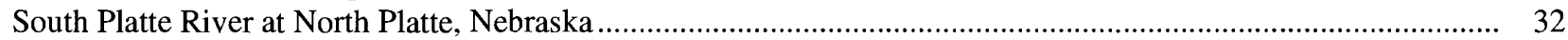

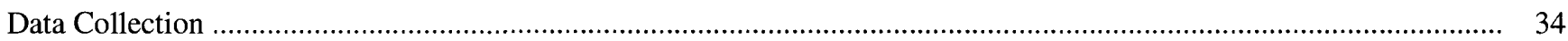

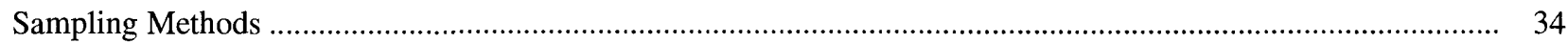

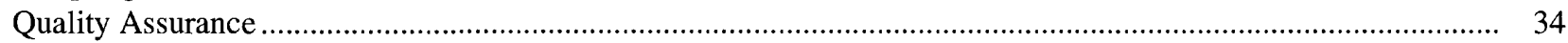

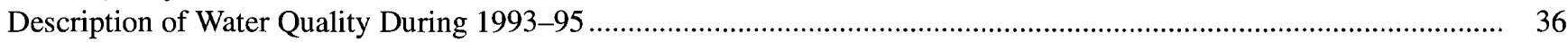

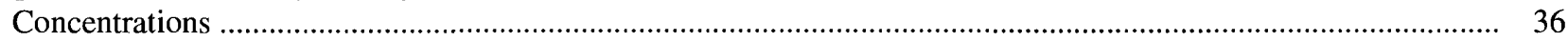

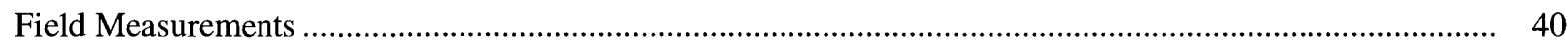

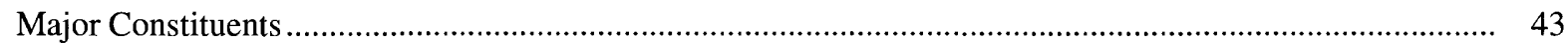

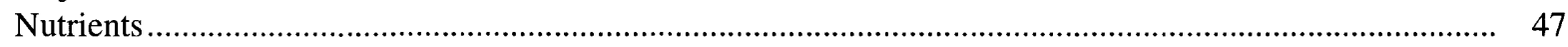

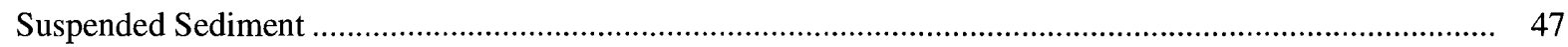

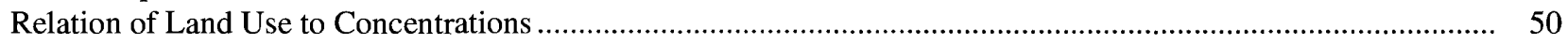

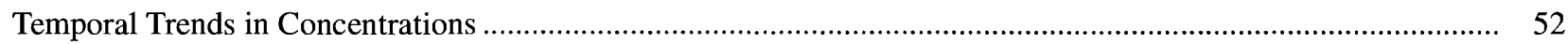

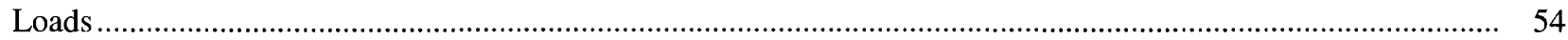

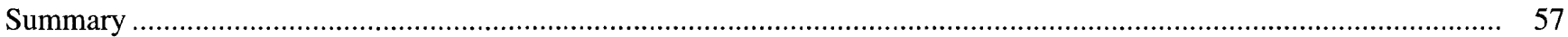

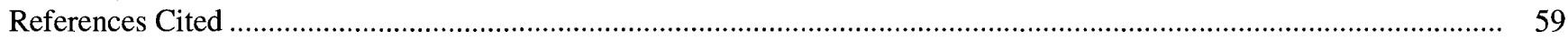

\section{FIGURES}

1. Map showing location of the study unit and fixed sites in the South Platte River Basin ................................... 3

2. Chart showing stratification scheme for Indicator Sites in the South Platte River Basin ................................. 6

3-14. Maps showing stream basin and land use upstream from the fixed site, hydrograph showing streamflow at the fixed site during the study period, and photograph showing typical character of the stream at the fixed site:

3. Cherry Creek at Denver, Colorado ......

4. South Platte River at Denver, Colorado.

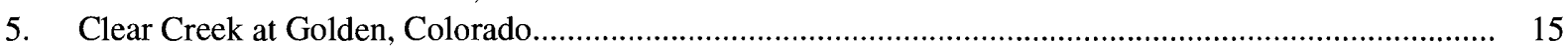

6. South Platte River at Henderson, Colorado ............................................................................ 17

7. St. Vrain Creek at mouth, near Platteville, Colorado ........................................................................... 19

8. Big Thompson River below Moraine Park, near Estes Park, Colorado ................................................ 21

9. Cache la Poudre River at mouth of canyon, near Fort Collins, Colorado ............................................ 23

10. Lonetree Creek at Carr, Colorado ....................................................................................... 25

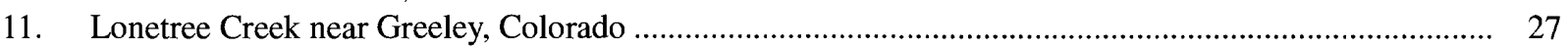

12. South Platte River near Kersey, Colorado ....................................................................................... 29

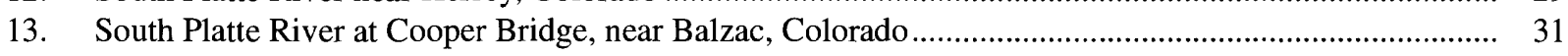

14. South Platte River at North Platte, Nebraska..................................................................................... 
15. Boxplots showing distributions of water temperature, dissolved-oxygen concentration, specific conductance, and $\mathrm{pH}$ at the fixed sites

16. Graph showing daily maximum, median, and minimum water temperatures during water year 1994 at South Platte River at Denver, Colorado, and Clear Creek at Golden, Colorado

17. Piper diagram showing major-ion composition at the fixed sites

18. Boxplots showing distributions of concentrations of dissolved sulfate, dissolved iron plus manganese, dissolved silica, and dissolved organic carbon at the fixed sites

19. Boxplots showing distributions of concentrations of total nitrogen, total phosphorus, and suspended sediment at the fixed sites.

20. Trilinear diagram showing median proportional composition of total nitrogen concentration at the fixed sites

21-23. Graphs showing:

21. Concentrations of dissolved nitrate at South Platte River at Cooper Bridge, near Balzac, Colorado, 1963-96... 54

22. Monthly total-nitrogen loads at three fixed sites along the South Platte River, May 1993 through September 1995

23. Monthly suspended-sediment loads at three fixed sites along the South Platte River, May 1993 through September 1995

\section{TABLES}

1. Water-quality data collected at the fixed sites

2. Selected site characteristics for the fixed sites in the South Platte River Basin.................................................. 7

3. Streamflow statistics for the fixed sites in the South Platte River Basin ..........................................................

4. Summary of quality-assurance data from fixed-site sampling .......................................................................... 35

5. Selected chronic stream-segment standards for the fixed sites ......................................................................... 38

6. Summary of water quality for major land-use categories ........................................................................

7. Historical trends in selected water-quality constituents at the fixed sites along the South Platte River, 1963-96.

8. Mean annual loads at the fixed sites for selected water-quality constituents 


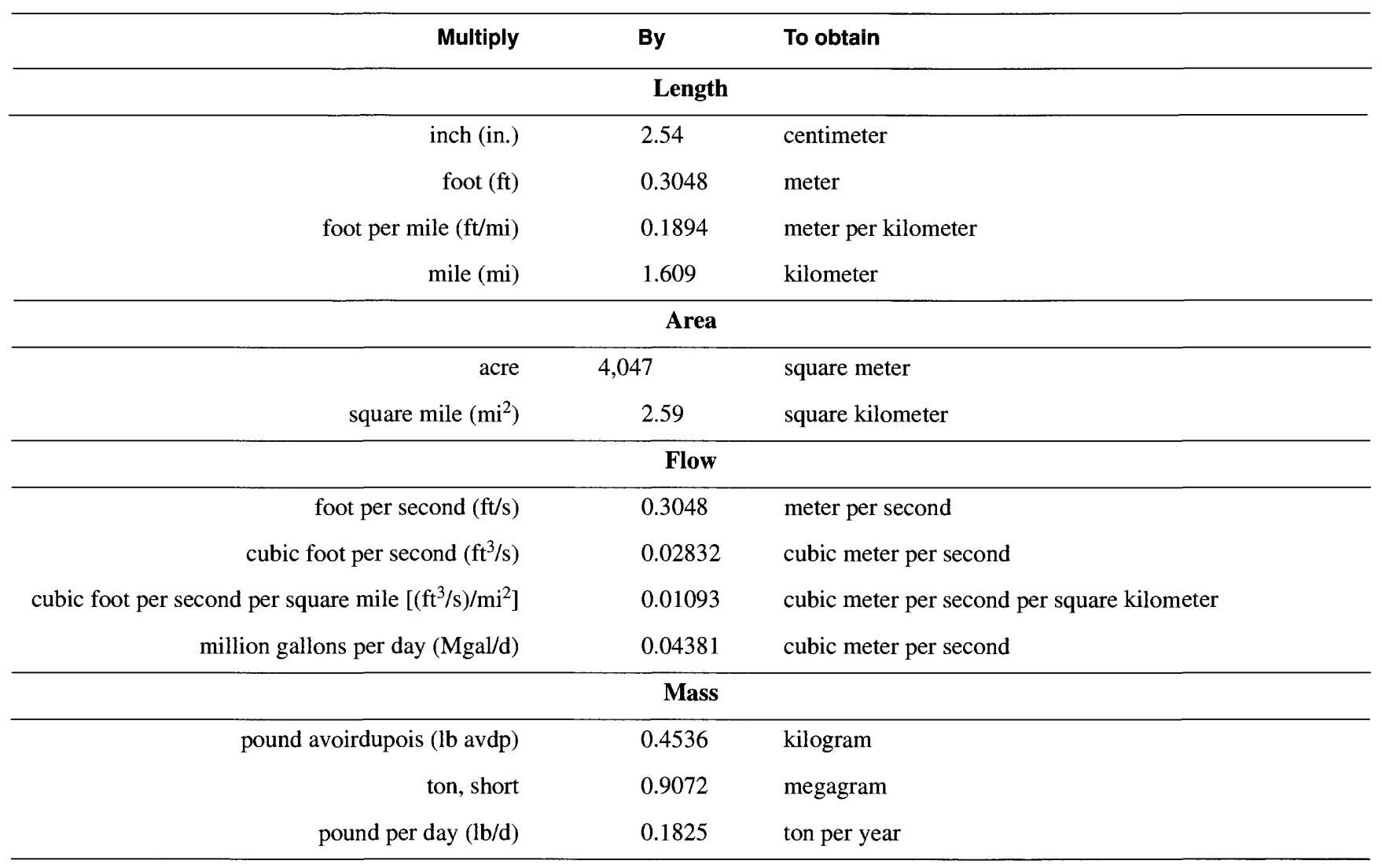

Temperature in degrees Celsius $\left({ }^{\circ} \mathrm{C}\right)$ may be converted to degrees Fahrenheit $\left({ }^{\circ} \mathrm{F}\right)$ as follows:

${ }^{\circ} \mathrm{F}=1.8{ }^{\circ} \mathrm{C}+32$

ADDITIONAL ABBREVIATIONS

$\mu \mathrm{g} / \mathrm{L} \quad$ microgram per liter

$\mu \mathrm{m} \quad$ micrometer

$\mu \mathrm{S} / \mathrm{cm} \quad$ microsiemens per centimeter at 25 degrees Celsius

$\mathrm{mg} / \mathrm{L} \quad$ milligram per liter

$\mathrm{mm} \quad$ millimeter

MCL Maximum Contaminant Level

USEPA U.S. Environmental Protection Agency

USGS U.S. Geological Survey 


\title{
Water-Quality Assessment of the South Platte River Basin, Colorado, Nebraska, and Wyoming-Environmental Setting and Water Quality of Fixed Sites, 1993-95
}

\author{
By David W. Litke and Robert A. Kimbrough
}

\section{ABSTRACT}

In 1991, the U.S. Geological Survey (USGS) began full-scale implementation of the National Water-Quality Assessment (NAWQA) Program, with the objectives of describing the status and trends in the quality of a large, representative part of the Nation's surface- and groundwater resources and of providing a sound scientific understanding of the primary natural and human factors affecting the quality of these resources. The South Platte River Basin was among the first 20 NAWQA study units selected for study under the full-scale implementation plan. Twelve fixed sites were established on streams in the South Platte River Basin to provide data to support the objectives of the NAWQA study. The sites were selected to represent forest land use (three sites), agricultural land use (three sites), urban land use (three sites), mixed urban/agricultural land use (two sites), and rangeland use (one site). This report describes the environmental setting and hydrologic conditions at the sites, summarizes monthly data collected at the sites, discusses the effects of land use on concentrations, evaluates historical trends in concentrations at selected sites, and presents estimates of stream loads for selected constituents.

The 12 fixed sites were sampled monthly from March 1993 to September 1995. Constituents determined from monthly sampling included field measurements and concentrations of major constituents, organic carbon, nutrients, and suspended sediment. Concentration data were

compared to stream standards as points of reference for water quality. There were occasional occurrences of constituent concentrations exceeding chronic stream-segment standards for sulfate, iron, nitrite, and un-ionized ammonia. However, there were more common exceedances of chronic standards for manganese at one forest site, two urban sites, and one mixed urban/agricultural site. The U.S. Environmental Protection Agency (USEPA) recommended limit for total phosphorus concentrations in streams $(0.1$ milligram per liter) for the control of eutrophication was exceeded at all urban, agricultural, and mixed urban/agricultural sites and at one forest site; the minimum measured phosphorus concentration at most of these sites also exceeded the recommended limit.

Land use was a statistically significant classifying variable for all of the water-quality constituents. For some constituents (specific conductance, water temperature, dissolved solids, and sodium), each land use was significantly different from all others. For other constituents (for example, nitrite plus nitrate), there were as few as two significant classes. Water quality generally was best (significantly smaller median concentrations) for rangeland and forest land use. Mixed urban/agricultural land use had the poorest water quality (significantly larger median concentrations) among the land uses sampled, which was attributed to the combined inputs of urban and agricultural land use. 
Seasonal Kendall trend tests on combined USGS and USEPA data for 1963-96 detected downward trends in salinity at sites along the South Platte River, whereas nitrate concentrations had upward trends. Streamflow had upward trends at sites along the river, but the salinity and nitrate concentration trends still were significant after being adjusted for variability in streamflow.

Daily loads were estimated at the fixed sites for dissolved solids, total nitrogen, total phosphorus, and suspended sediment for March 1993 to September 1995. Loads were largest at South Platte River near Kersey, Colorado, where streamflow also was largest; mean annual loads at this site for water years 1994-95 were 810,000 tons of dissolved solids, 510,000 tons of suspended sediment, 880 tons of total phosphorus, and 6,400 tons of total nitrogen. The downstream pattern of mean annual loads along the South Platte River was similar for the four constituents; loads increased from Denver to Kersey, Colorado, and decreased from Kersey to North Platte, Nebraska.

\section{INTRODUCTION}

In 1991, the U.S. Geological Survey (USGS) began full-scale implementation of the National Water-Quality Assessment (NAWQA) Program. The objectives of the NAWQA Program are to describe the status and trends in the quality of a large, representative part of the Nation's surface- and ground-water resources and to provide a sound scientific understanding of the primary natural and human factors affecting the quality of these resources (Leahy and others, 1990). The South Platte River Basin was among the first 20 NAWQA study units selected for study under the full-scale implementation plan (Dennehy, 1991).

Fixed sites are an integral element of the surface-water design for NAWQA study units (Gilliom and others, 1995). They are sites on streams where streamflow is measured and samples are collected monthly to assess the broad-scale spatial and temporal character and the transport of inorganic constituents of stream water in relation to environ- mental setting and hydrologic conditions. Twelve fixed sites were established in the South Platte River Basin and were sampled from March 1993 to September 1995. Data were collected on watercolumn chemistry (discussed in this report); on organic compounds and trace elements in streambed sediment and fish tissue (Tate and Heiny, 1996; Heiny and Tate, 1997); on algal, benthic-invertebrate, and fish communities (Tate and Heiny, 1995); and on aquatic habitat (C.M. Tate, U.S. Geological Survey, oral commun., 1997).

\section{Purpose and Scope}

This report (1) describes the environmental setting at the 12 fixed sites in the South Platte River Basin, (2) summarizes water-quality concentration data collected at the fixed sites during the study period, (3) discusses the effects of land use on concentrations at the fixed sites, (4) evaluates historical trends in concentrations at selected sites, and (5) presents estimates of stream loads for selected constituents. The descriptions of environmental setting focus primarily on land use and on hydrologic conditions at the sites - characterization of land use for a site requires some knowledge of the source of water at that site. The presentation of data focuses on those constituents collected as part of regular monthly sampling; namely, field measurements and concentrations of major constituents, organic carbon, nutrients, and suspended sediment (table 1). The discussion on the effect of land use on concentrations examines the variability of water quality between and within land uses. Historical trends in concentrations at five selected sites on the South Platte River are analyzed by combining NAWQA data with data from other agencies that are available through the U.S. Environmental Protection Agency Storage and Retrieval System (STORET). Daily stream loads during March 1993 to September 1995 are estimated for dissolved solids, total nitrogen, total phosphorus, and suspended sediment, and loads are compared between sites.

\section{Description of South Platte River Basin}

The South Platte River Basin (fig. 1) has a drainage area of about $24,300 \mathrm{mi}^{2} ; 79$ percent of the basin is in Colorado, 15 percent is in Nebraska, and 


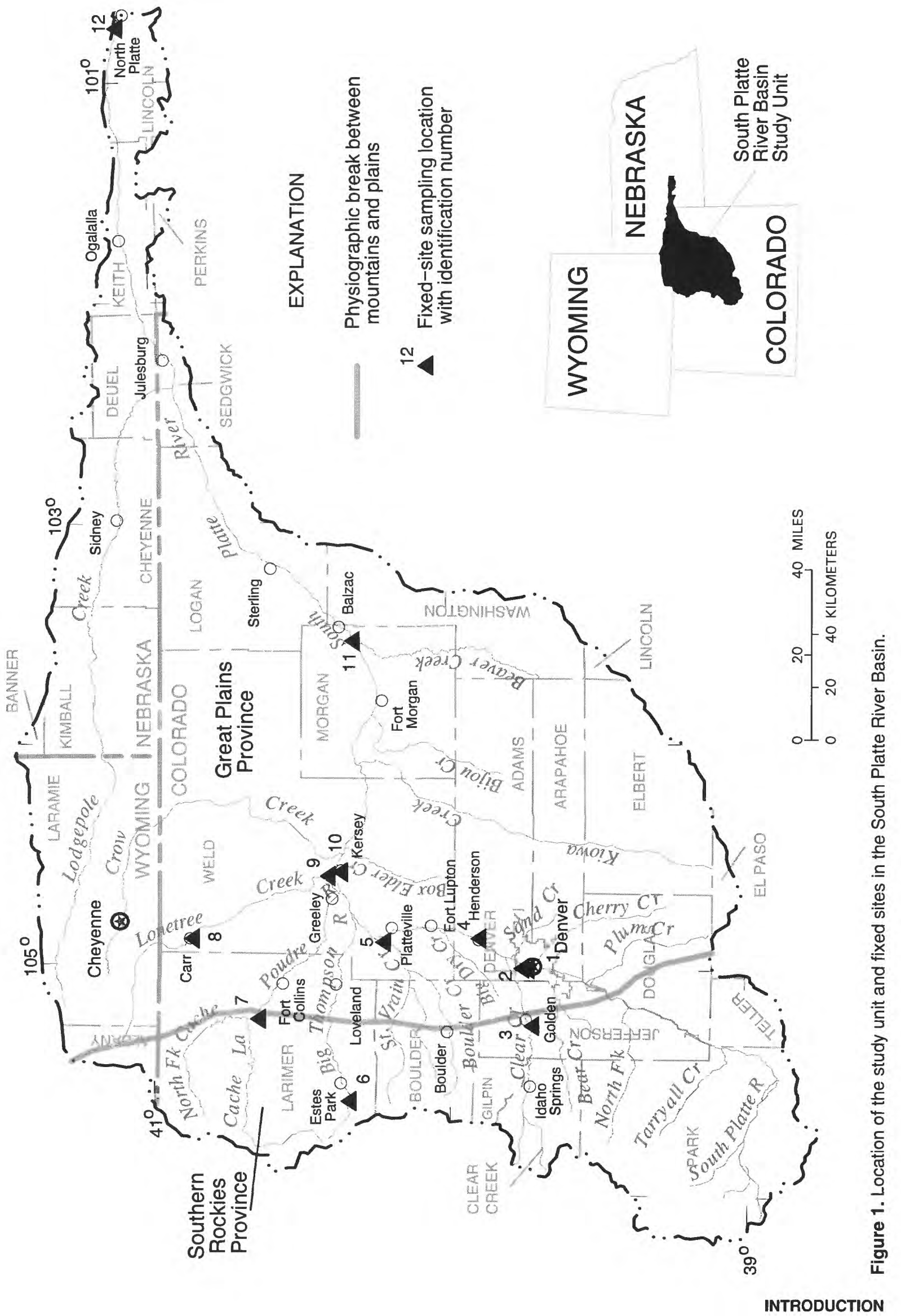


Table 1. Water-quality data collected at the fixed sites

\section{Field measurements}

Water temperature (hourly for 1 year)

Dissolved oxygen

Specific conductance

$\mathrm{pH}$ and alkalinity

Major constituents:

Laboratory analyses ${ }^{1}$

Dissolved solids

Major ions and metals:

Calcium

Chloride

Fluoride

Iron

Magnesium

Manganese

Potassium

Silica

Sodium

Sulfate

Organic carbon:

Suspended

Dissolved

Nutrients:

Nitrogen:

Total organic nitrogen plus ammonia

Dissolved organic nitrogen plus ammonia

Ammonia

Nitrite

Nitrite plus nitrate

Phosphorus:

Total

Dissolved

Orthophosphate

Suspended sediment

${ }^{1}$ Analyses are for dissolved constituent unless otherwise listed. 6 percent is in Wyoming. The South Platte River originates in the mountains of central Colorado and flows about 450 mi northeast across the Great Plains to its confluence with the North Platte River at North Platte, Nebraska. The major tributaries of the South Platte River (Clear Creek, St. Vrain Creek, Big Thompson River, and Cache la Poudre River) are perennial streams that originate in the Rocky Mountains; plains streams (Kiowa Creek, Bijou Creek, Beaver Creek, and Lodgepole Creek) are ephemeral and contribute little water to the South Platte River during most years. The South Platte alluvial-aquifer system, which is $4,000 \mathrm{mi}^{2}$ in area and is located in the alluvial valley and benchlands of the South Platte River and its tributaries, is hydraulically connected to the river and contributes substantial flow to the river.

Dennehy and others (1993) have described the natural factors (physiography, climate, geology, and soils) and anthropogenic factors (population, land use, and water use) that contribute to environmental settings in the South Platte River Basin. There are two physiographic provinces in the South Platte River Basin-the Southern Rockies Province (the western one-quarter of the basin) and the Great Plains Province (the eastern three-quarters of the basin). The mountains and the plains are different in almost all aspects of environmental setting.

Annual precipitation in the basin varies from less than 15 in. to more than $60 \mathrm{in}$.; amounts larger than $20 \mathrm{in}$. occur only in the mountains primarily as snowfall; amounts smaller than $20 \mathrm{in}$. occur primarily in the plains as rainfall. There are two primary rock types in the basin - crystalline rock of Precambrian age, which underlies most of the Southern Rockies Province, and younger sedimentary rock, which underlies most of the Great Plains Province. Alluvial and colluvial deposits overlie the bedrock in river valleys in the mountains and in the plains. Soils in the mountains generally are thin (less than $20 \mathrm{in}$.), contain less than 25 percent clay, and are acidic. Soils in the plains generally are thick (greater than $60 \mathrm{in}$.), clayey (greater than 25 percent clay), and have as much as 5 percent organic matter.

Land use in the basin is 41 percent rangeland, 37 percent agricultural, 16 percent forest, 3 percent urban or built-up, and 3 percent other. Among these land uses, urban and agricultural have the largest effect on water quality (Dennehy and others, 1995). The population of the basin was about 2.4 million in 1990 and about 2.7 million in 1995 [data are from the U.S. Geological Survey's Aggregate Water-Use Data System (AWUDS)]. About 90 percent of this population is clustered in the Front Range urban corridor (10 percent of the basin), which is located where the mountains meet the plains and is oriented in a northsouth direction from Denver to Fort Collins, Colorado (fig. 1). Wastewater-treatment plants located in the urban areas discharge a total of about $280 \mathrm{Mgal} / \mathrm{d}$ of effluent. Agricultural land use includes about 1.1 million acres of irrigated land that is located 
primarily in the benchlands and the alluvial valleys along the South Platte River and its major tributaries. About $2,800 \mathrm{Mgal} / \mathrm{d}$ of irrigation water is applied to agricultural lands, and a substantial part of this water returns to the river via ground-water and surface-water return flows.

\section{Acknowledgments}

The authors acknowledge the contributions of Dennis E. Smits, USGS, Colorado District, who collected most of the water samples on which this report is based. The authors appreciate the care taken by Dennis as well as his thoughtful field observations of water-quality conditions. Thanks also to Jonathan B. Evans and Jeffrey R. Deacon of the USGS who assisted in sample collection during times of high water and when sampling was most intense.

\section{SELECTION OF FIXED SITES}

The NAWQA study design includes two types of fixed sites: Integrator Sites and Indicator Sites (Gilliom and others, 1995). Integrator Sites are selected to represent water-quality conditions of rivers in heterogenous large basins that are affected by complex combinations of environmental settings. In the South Platte River Basin, two Integrator Sites were selected, one on a major tributary to the South Platte River (St. Vrain Creek at mouth, near Platteville, Colorado), and one on the South Platte River where streamflow is the largest (South Platte River near Kersey, Colorado).

Indicator Sites, in contrast, are selected to represent water-quality conditions of streams in relatively homogenous areas. In the South Platte River Basin, homogenous areas were defined by using a stratification scheme based on physiographic province, geology, and land use (fig. 2). In the basin, there are two physiographic provinces (Southern Rockies and Great Plains), two principal types of rocks (Precambrian crystalline and younger sedimentary), and four primary land uses (agricultural, urban, forest, and rangeland). There are 16 possible combinations (strata) for these three factors, but just four of these strata predominate in the basin. Forest land use primarily is in the mountains (Southern Rockies Province), which are underlain by Precambrian crystalline bedrock. Three Indicator Sites were chosen to represent this stratum. One forest Indicator Site (Clear Creek at Golden, Colorado) is located in a moderately large basin that is affected by a busy interstate highway corridor, dispersed rural population, and abandoned mining operations. A second forest Indicator Site is located in a small mountain basin in Rocky Mountain National Park (Big Thompson River below Moraine Park, near Estes Park, Colorado) where conditions are pristine. A third forest Indicator Site (Cache la Poudre River at mouth of canyon, near Fort Collins, Colorado) is located in a moderately large basin that is affected by a highway corridor along the river and recreational use of the river. Agricultural land use primarily is on the plains (Great Plains Province) in alluvial valleys underlain by sedimentary bedrock. Three Indicator Sites were chosen to represent this stratum, one site in a small agricultural basin (Lonetree Creek near Greeley, Colorado) and two sites on the South Platte River in predominantly agricultural areas (South Platte River at Cooper Bridge, near Balzac, Colorado, and South Platte River at North Platte, Nebraska). Urban land use primarily is on the plains in alluvial valleys underlain by sedimentary bedrock. Three Indicator Sites were chosen to represent this stratum, one site in a small urban basin (Cherry Creek at Denver, Colorado) and two sites on the South Platte River in predominantly urban areas (South Platte River at Denver, Colorado, and South Platte River at Henderson, Colorado). Rangeland primarily is in the plains underlain by sedimentary bedrock and is represented by a single small-basin Indicator Site (Lonetree Creek at Carr, Colorado).

\section{ENVIRONMENTAL SETTING OF FIXED SITES}

Although physiographic province, geology, and land use were the environmental factors used in the stratification scheme for the South Platte River Basin, other factors, such as physical habitat and hydrologic conditions are important components of the environmental setting that affect water quality of the fixed site. Selected site characteristics for the fixed sites are listed in table 2 . The drainage area ranged from 39 to $24,300 \mathrm{mi}^{2}$, and mean streamflow during the study period ranged from 0.5 to $1,330 \mathrm{ft}^{3} / \mathrm{s}$. 


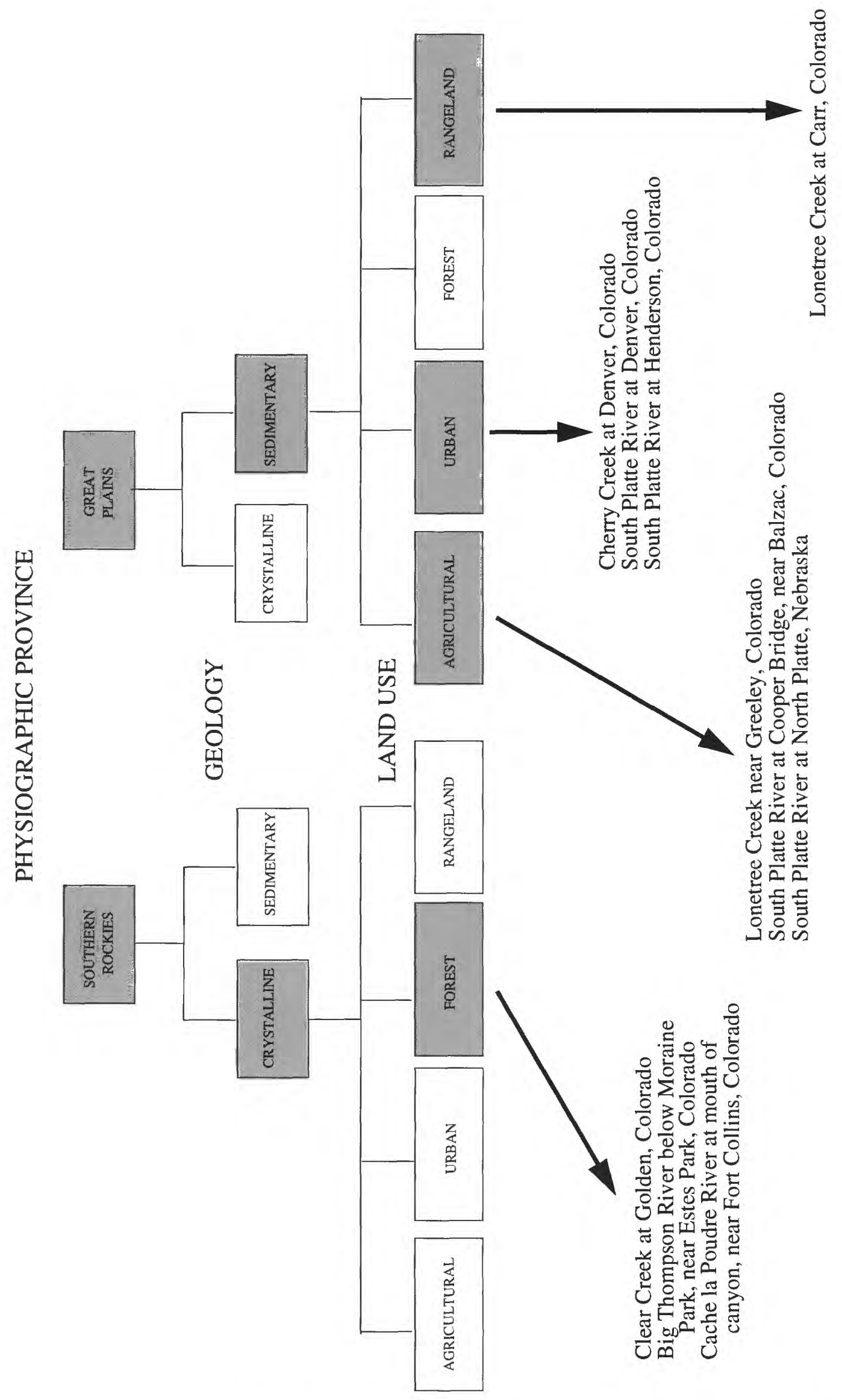

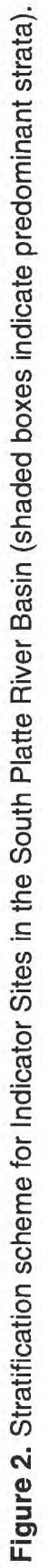


Table 2. Selected site characteristics for the fixed sites in the South Platte River Basin

[USGS, U.S. Geological survey; $\mathrm{mi}^{2}$, square miles; $\mathrm{ft}^{3} / \mathrm{s}$, cubic feet per second; $\mathrm{ft} / \mathrm{s}$, feet per second; ft/mi, feet per mile; ft, feet; --, no data]

\begin{tabular}{|c|c|c|c|c|c|c|c|c|}
\hline $\begin{array}{c}\text { Site } \\
\text { number } \\
\text { (fig. 1) }\end{array}$ & Site name & USGS number & $\begin{array}{l}\text { Latitude- } \\
\text { longitude }\end{array}$ & $\begin{array}{c}\text { Drainage } \\
\text { area } \\
\left(\mathbf{m i}^{2}\right)\end{array}$ & $\begin{array}{c}\text { Physiographic } \\
\text { province }\end{array}$ & $\begin{array}{l}\text { Bedrock } \\
\text { type }\end{array}$ & $\begin{array}{c}\text { Pre- } \\
\text { dominant } \\
\text { land use }\end{array}$ & $\begin{array}{l}\text { Fixed- } \\
\text { site } \\
\text { type }\end{array}$ \\
\hline 1 & Cherry Creek at Denver, Colorado & 06713500 & $\begin{array}{r}39^{\circ} 44^{\prime} 58^{\prime \prime} \\
105^{\circ} 00^{\prime} 08^{\prime \prime}\end{array}$ & 409 & Great Plains & Sedimentary & Urban & Indicator \\
\hline 2 & South Platte River at Denver, Colorado & 06714000 & $\begin{array}{r}39^{\circ} 45^{\prime} 35^{\prime \prime} \\
105^{\circ} 00^{\prime} 10^{\prime \prime}\end{array}$ & 3,861 & Great Plains & Sedimentary & Urban & Indicator \\
\hline 3 & Clear Creek at Golden, Colorado & 06719505 & $\begin{aligned} 39^{\circ} 45^{\prime} 11^{\prime \prime} \\
105^{\circ} 14^{\prime} 05^{\prime \prime}\end{aligned}$ & 400 & Southern Rockies & Crystalline & Forest & Indicator \\
\hline 4 & $\begin{array}{l}\text { South Platte River at Henderson, } \\
\text { Colorado }\end{array}$ & 06720500 & $\begin{aligned} 39^{\circ} 55^{\prime} 19^{\prime \prime} \\
104^{\circ} 52^{\prime} 00^{\prime \prime}\end{aligned}$ & 4,713 & Great Plains & Sedimentary & Urban & Indicator \\
\hline 5 & $\begin{array}{l}\text { St. Vrain Creek at mouth, near } \\
\text { Platteville, Colorado }\end{array}$ & 06731000 & $\begin{array}{r}40^{\circ} 15^{\prime} 29^{\prime \prime} \\
104^{\circ} 52^{\prime} 45^{\prime \prime}\end{array}$ & 976 & Great Plains & Sedimentary & $\begin{array}{l}\text { Urban/ } \\
\text { agricultural }\end{array}$ & Integrator \\
\hline 6 & $\begin{array}{l}\text { Big Thompson River below Moraine } \\
\text { Park, near Estes Park, Colorado }\end{array}$ & 402114105350101 & $\begin{aligned} 40^{\circ} 21^{\prime} 14^{\prime \prime} \\
105^{\circ} 35^{\prime} 01^{\prime \prime}\end{aligned}$ & 39 & Southern Rockies & Crystalline & Forest & Reference \\
\hline 7 & $\begin{array}{l}\text { Cache la Poudre River at mouth of } \\
\text { canyon, near Fort Collins, Colorado }\end{array}$ & 06752000 & $\begin{aligned} 40^{\circ} 39^{\prime} 52^{\prime \prime} & 105^{\circ} 13^{\prime} 26^{\prime \prime}\end{aligned}$ & 1,056 & Southern Rockies & Crystalline & Forest & Indicator \\
\hline 8 & Lonetree Creek at Carr, Colorado & 06753400 & $\begin{aligned} 40^{\circ} 53^{\prime} 54^{\prime \prime} \\
104^{\circ} 52^{\prime} 03^{\prime \prime}\end{aligned}$ & 167 & Great Plains & Sedimentary & Rangeland & Indicator \\
\hline 9 & Lonetree Creek near Greeley, Colorado & 06753990 & $\begin{array}{r}40^{\circ} 26^{\prime} 33^{\prime \prime} \\
104^{\circ} 35^{\prime} 18^{\prime \prime}\end{array}$ & 567 & Great Plains & Sedimentary & Agricultural & Indicator \\
\hline 10 & $\begin{array}{l}\text { South Platte River near Kersey, } \\
\text { Colorado }\end{array}$ & 06754000 & $\begin{aligned} 40^{\circ} 24^{\prime} 44^{\prime \prime} \\
104^{\circ} 33^{\prime} 46^{\prime \prime}\end{aligned}$ & 9,598 & Great Plains & Sedimentary & $\begin{array}{l}\text { Urban/ } \\
\text { agricultural }\end{array}$ & Integrator \\
\hline 11 & $\begin{array}{l}\text { South Platte River at Cooper Bridge, } \\
\text { near Balzac, Colorado }\end{array}$ & 06759910 & $\begin{array}{r}40^{\circ} 21^{\prime} 23^{\prime \prime} \\
103^{\circ} 31^{\prime} 30^{\prime \prime}\end{array}$ & 16,852 & Great Plains & Sedimentary & Agricultural & Indicator \\
\hline 12 & $\begin{array}{l}\text { South Platte River at North Platte, } \\
\text { Nebraska }\end{array}$ & 06765500 & $\begin{array}{r}41^{\circ} 07^{\prime} 05^{\prime \prime} \\
100^{\circ} 46^{\prime} 22^{\prime \prime}\end{array}$ & 24,300 & Great Plains & Sedimentary & Agricultural & Indicator \\
\hline
\end{tabular}

\begin{tabular}{|c|c|c|c|c|c|c|c|c|c|}
\hline Site name & $\begin{array}{c}\text { Mean } \\
\text { streamflow } \\
\left(\mathrm{ft}^{3} / \mathrm{s}\right)\end{array}$ & $\begin{array}{c}\text { Median } \\
\text { velocity }{ }^{2} \\
(\mathrm{ft} / \mathrm{s})\end{array}$ & $\begin{array}{l}\text { Stream } \\
\text { gradient } \\
(\mathrm{ft} / \mathrm{mi})\end{array}$ & Stream type & Sinuosity ${ }^{3}$ & $\begin{array}{c}\text { Mean } \\
\text { width } \\
(\mathrm{ft})\end{array}$ & $\begin{array}{l}\text { Percent } \\
\text { open } \\
\text { canopy } 4\end{array}$ & $\begin{array}{c}\text { Bank } \\
\text { stability }\end{array}$ & $\begin{array}{l}\text { Pre- } \\
\text { dominant } \\
\text { substrate }\end{array}$ \\
\hline Cherry Creek at Denver, Colorado & 28 & 1.47 & 27.4 & Channelized & 1.07 & 32 & 53 & 4.0 & Sand \\
\hline South Platte River at Denver, Colorado & 400 & 1.36 & 18.9 & Channelized & 1.04 & 122 & 61 & 4.0 & Sand \\
\hline Clear Creek at Golden, Colorado & 233 & 2.02 & 57.2 & Meandering & 1.02 & 42 & 57 & 3.1 & Cobble \\
\hline South Platte River at Henderson, Colorado & 610 & 1.43 & 6.72 & Meandering & 1.13 & 109 & 80 & 3.4 & Cobble \\
\hline $\begin{array}{l}\text { St. Vrain Creek at mouth, near } \\
\text { Platteville, Colorado }\end{array}$ & 322 & 2.00 & 5.98 & Meandering & 1.23 & 74 & 88 & 2.9 & Gravel \\
\hline $\begin{array}{l}\text { Big Thompson River below Moraine Park, } \\
\text { near Estes Park, Colorado }\end{array}$ & -- & -- & 41.0 & Meandering & 1.20 & -- & -- & -- & -- \\
\hline $\begin{array}{l}\text { Cache la Poudre River at mouth of canyon, } \\
\text { near Fort Collins, Colorado }\end{array}$ & 366 & 1.14 & 29.1 & Meandering & 1.36 & 100 & 72 & 3.1 & Cobble \\
\hline Lonetree Creek at Carr, Colorado & 0.5 & 0.45 & 35.1 & Meandering & 1.38 & 10 & 64 & 3.8 & Gravel/cobble \\
\hline Lonetree Creek near Greeley, Colorado & 15 & 1.43 & 23.2 & Straight & 1.36 & 12 & 100 & 2.8 & Sand \\
\hline South Platte River near Kersey, Colorado & 1,330 & 2.19 & 6.19 & Meandering & 1.14 & 122 & 72 & 2.3 & Gravel \\
\hline $\begin{array}{l}\text { South Platte River at Cooper Bridge, near } \\
\text { Balzac, Colorado }\end{array}$ & 891 & 1.66 & 7.83 & Braided & 1.17 & 302 & 81 & 2.7 & Sand \\
\hline $\begin{array}{l}\text { South Platte River at North Platte, } \\
\text { Nebraska }\end{array}$ & 719 & -- & 8.04 & Braided & 1.06 & 177 & 83 & 3.2 & Sand \\
\hline
\end{tabular}

Nebraska

${ }^{1}$ For period of study, March 1993-September 1995.

${ }^{2}$ Median of mean velocity at time of site visits during period of study, March 1993-September 1995.

${ }^{3}$ River distance divided by straight-line distance; a value of 1.00 is a straight line.

${ }^{4}$ Expressed as percent of open viewing angle; 100 percent indicates no canopy.

${ }^{5}$ Rated on a scale from 1 (signifying less than 25 percent of banks are covered with vegetation or gravel or larger material) to 4 (signifying more than 80 percent of banks are covered with vegetation or gravel or larger material). 
More than 34 riparian and instream habitat characteristics (Meador and others, 1993) were measured at NAWQA fixed sites to document the local stream environment in which the local biota (algae, macroinvertebrates, and fish) live. Several of the habitat characteristics also could relate to stream water quality and are listed in table 2. For example, median velocity, stream gradient, bank stability, and predominant substrate are all related to the power of a stream to transport suspended loads of sediment and nutrients. Analysis of NAWQA data has determined significant relations between stream water quality and habitat characteristics (C.M. Tate, U.S. Geological Survey, oral commun., 1997).

Hydrologic conditions can have a substantial effect on water quality due to the quantity of water in rivers. Increased streamflow can improve water quality by dilution, but increased flow also can impair water quality by mobilizing and transporting additional material. Streamflow statistics for the study period for the fixed sites (table 3 ) indicated that streamflow varied substantially from year to year. Data in this table are summarized by water year, which begins in October; water year 1993, for example, includes October 1, 1992, through September 30, 1993. Compared with the 20-year (1976-95) mean streamflow, flow at the fixed sites averaged 69 percent of the mean during water year 1993, 56 percent of the mean during water year 1994 , and 180 percent of the mean during water year 1995. Water year 1993 had substantially less than normal flows mostly at plains sites, whereas water year 1994 had less than normal flows at mountain and plains sites. Water year 1995 had a large snowpack in the mountains in addition to a rainy May in the plains, which resulted in flooding in both environments and in the largest sustained 60-day flows of record at many of the fixed sites.

Hydrologic conditions also can affect water quality due to changing sources of water. In the South Platte River Basin, as in other parts of the arid West, water is routed through a variety of artificial structures to meet water demands of cities and agricultural users. As a result, the contributing sources of water at a fixed site can vary daily, with each source being affected by different land uses, and characterization of the land use at a site requires information about the various water sources. Because water is removed from the entire length of the river, water at a site often is derived more from local sources than from upstream sources, resulting in local land use being more important than basinwide land use. 


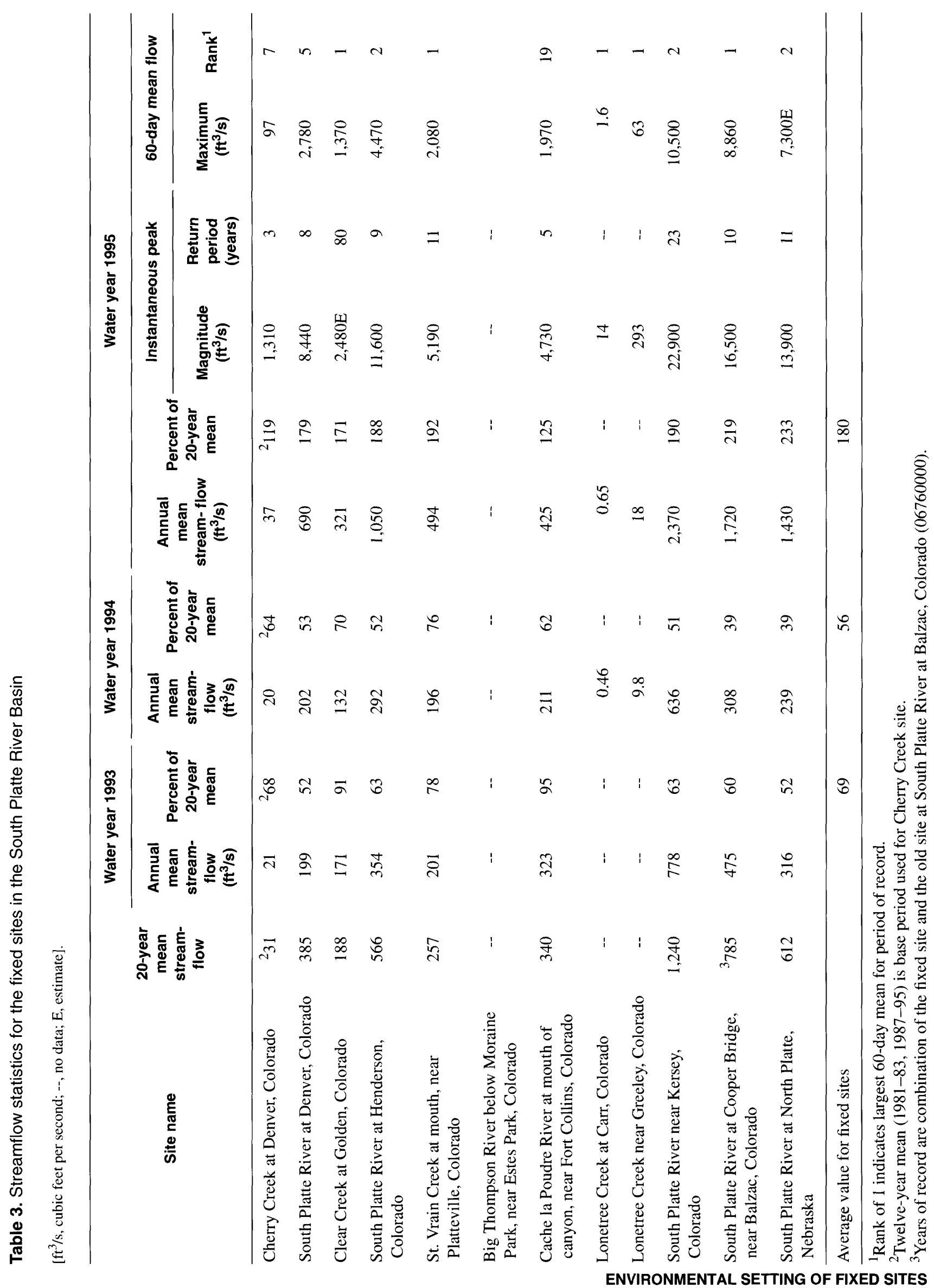




\section{Cherry Creek at Denver, Colorado}

Cherry Creek originates on the southern border of the South Platte River Basin (fig. 3) and flows northward through rangeland, valley-bottom hay fields, and occasional low-density residential developments before entering Cherry Creek Reservoir, located on the southern edge of the Denver, Colorado, metropolitan area. Downstream from the reservoir, Cherry Creek flows through predominantly urbanized land before flowing into the South Platte River in downtown Denver. The fixed site is located $0.5 \mathrm{mi}$ upstream from the confluence with the South Platte River.

Cherry Creek flows through the Great Plains physiographic province. The basin is underlain by lower Tertiary to Upper Cretaceous sandstone and shale of the Denver Formation, which occasionally crop out in the streambed, but alluvium and colluvium as much as $200 \mathrm{ft}$ thick overlie most of the basin.

The active channel of Cherry Creek is incised about $15 \mathrm{ft}$ below the land surface and is channelized through most of the lower basin. The stream in the 5-mi reach just downstream from the reservoir generally flows through wetlands and parks and is constrained by natural banks. The stream in the 5-mi reach just upstream from the fixed site is constrained by retaining walls at a level about $15 \mathrm{ft}$ below street level. The retaining walls create an artificial canopy cover for the creek, allowing sunlight to reach the water only about 50 percent of the time.

Residential construction; channel improvements, including bike-path construction; and the construction of a highway underpass adjacent to the channel were done during the study period. Because the stream channel has been modified by man, the sinuosity (1.07) is among the lowest of the sites, and the bank stability (4.0) is among the largest of the sites (table 2).

Land use in the entire $409-\mathrm{mi}^{2}$ Cherry Creek Basin upstream from the fixed site at Denver, Colorado, is 40 percent rangeland, 30 percent agricultural, 15 percent urban, 5 percent forest, and 10 percent other (Fegeas and others, 1983) (fig. 3). However, most of the water at the fixed site originates in the $23-\mathrm{mi}^{2}$ lower basin located downstream from Cherry Creek Reservoir (area of blowup in fig. 3). Land use in this part of the basin is almost entirely urban and is categorized as 48 percent residential, 18 percent commercial and industrial, 18 percent other urban land, and 16 percent other land use (Rodrigo, 1994). Much of the lower basin is covered with impermeable urban materials, and numerous urban drainage pipes discharge into the creek. The site is representative of urban land use.

Although Cherry Creek downstream from Cherry Creek Reservoir is classified for recreational use (secondary contact), water supply, and agricultural use, water from Cherry Creek is not removed for offstream use. However, ground water is pumped from the allu- vium for drinking water. Surface-water rights to Cherry Creek are appropriated, but diversion points are located farther downstream along the main stem of the South Platte River.

Mean streamflow at Cherry Creek at Denver, Colorado, during the study period was $28 \mathrm{ft}^{3} / \mathrm{s}$ (table 2); annual mean streamflows were less than the 20-year mean during water years 1993 and 1994 and greater than the 20-year mean during water year 1995 (table 3). The daily mean streamflow hydrograph for this site (fig. 3) shows that daily mean streamflows were fairly uniform, except when interrupted by short-term peaks caused by runoff from storms. Runoff from storms (rain storms and snowstorms) can occur throughout the year, and precipitation in the urban area in excess of about 0.1 in. can cause Cherry Creek to rise suddenly. During these storms, water in Cherry Creek changes from clear to black in color, and floating urban detritus (such as plastic containers and lawn clippings) is abundant. The lack of corresponding increased releases from Cherry Creek Reservoir during storms indicated that stormwater was derived almost entirely from the lower basin.

Releases from Cherry Creek Reservoir during the study period (fig. 3) contributed about 30 percent of the flow at the fixed site during February through July, but only about 10 percent of the flow from August through January. About 5 percent of the flow at the site was contributed by a small wastewater-treatment plant located in the lower basin that has a yearly discharge of about $1 \mathrm{Mgal} / \mathrm{d}\left(1.5 \mathrm{ft}^{3} / \mathrm{s}\right)$. On almost all days during the study period, most of the flow at the site was derived from urban base flow or urban storm runoff. Flow measurements along the creek that were done as part of the NAWQA studies during low-flow periods in 1993 and 1994 indicated that urban base flow consists primarily of water from the wastewater-treatment plant, discharge from the surrounding alluvial aquifer, and water discharged from urban drainage pipes, which also is mostly pumped or intercepted ground water (D.W. Litke, U.S. Geological Survey, unpublished data).

Forty-three water-quality samples were collected during the study period at Cherry Creek at Denver, Colorado (fig. 3). The range in flow conditions was well represented; the minimum flow sampled was $7.9 \mathrm{ft}^{3} / \mathrm{s}$, and the maximum flow sampled was $1,650 \mathrm{ft}^{3} / \mathrm{s}$. Samples sometimes were collected during flows considerably larger than the daily mean flow (fig. 3); these are storm samples that were sampled near the peak flow, which may only last for a few hours. About 15 samples were collected during urban storm runoff. 

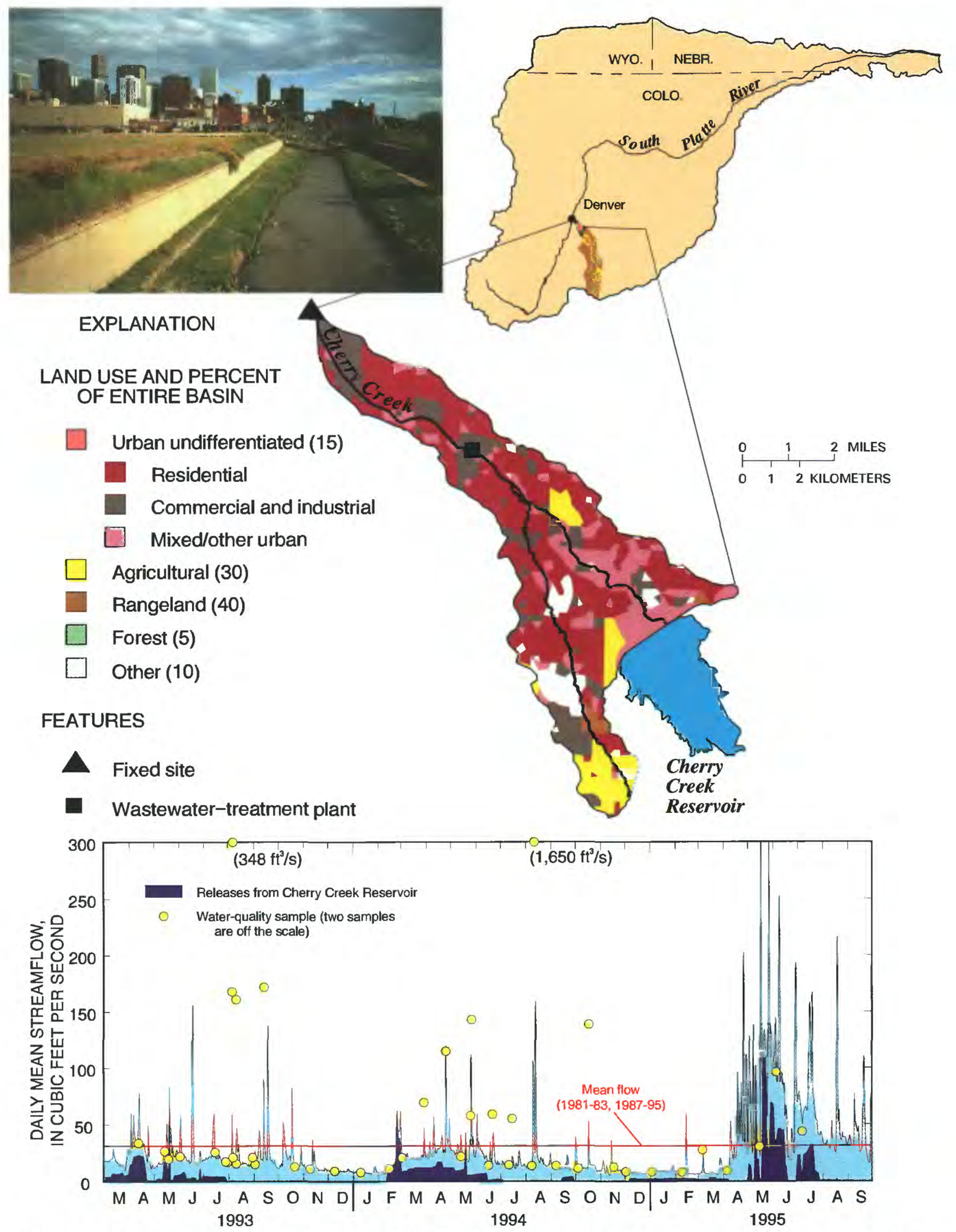

Figure 3. Map showing stream basin and land use (Fegeas and others, 1983; Rodrigo, 1994) upstream from the fixed site, hydrograph showing streamflow at the fixed site during the study period, and photograph showing typical character of the stream at the fixed site: Cherry Creek at Denver, Colorado. 


\section{South Platte River at Denver, Colorado}

The South Platte River originates in the Rocky Mountains in the southwestern part of the basin and flows east and northeast through forest and mountain rangeland to a point about $20 \mathrm{mi}$ from Denver, Colorado, where it enters the plains and then flows into Chatfield Reservoir (fig. 4). Downstream from the reservoir, the river continues to flow northeast through predominantly urban land use to the fixed site at Denver. The site is located just west of downtown Denver, 18 river miles downstream from Chatfield Reservoir and $0.4 \mathrm{mi}$ downstream from the confluence with Cherry Creek.

The South Platte River flows through the Southern Rockies physiographic province until it exits the mountains and flows through the Great Plains physiographic province. In the mountains, the basin primarily is underlain by Precambrian crystalline igneous and metamorphic rocks. Unlike mountainous areas to the north, there are no large gold or silver deposits in this area, and mining activity does not constitute a major land use in this part of the basin. In the plains, the basin is underlain by lower Tertiary to Upper Cretaceous sandstone and shale of the Denver Formation, which occasionally crop out in the streambed, but alluvium and colluvium as much as $200 \mathrm{ft}$ thick overlie the bedrock in most of the plains area of the basin.

The South Platte River from Chatfield Reservoir to the fixed site in Denver, Colorado, has been channelized as a result of gravel mining in the upper part of the segment and as a result of urban flood control in the lower part of the segment. Major urban projects were completed during the study in the flood plain of the South Platte River in the vicinity of the fixed site, including the construction of a baseball stadium and an amusement park. Extensive channel modifications were done during 1994-95 in a 3-mi segment just upstream from the site as part of channel regrading. Artificial aeration structures also have been built at several points along the channel. Because of channel alterations, sinuosity is small in the vicinity of the site, and bank stability is large (table 2). The percent of open canopy at the site is small due to high banks and occasional trees.

Land use in the entire 3,861- $\mathrm{mi}^{2}$ South Platte River Basin upstream from the fixed site at Denver, Colorado, is 47.7 percent forest, 34.8 percent rangeland, 5.9 percent agricultural, 5.3 percent urban, and 6.3 percent other landuse categories (Fegeas and others, 1983). However, most of the water from the forested headwaters is used as the municipal water supply for the Denver metropolitan area and is removed from the river upstream from Chatfield Reservoir and transported by pipes to water-treatment plants. A single mountain tributary (Bear Creek) contributes water to the South Platte River downstream from Chatfield Reservoir, but much of the water from this tributary also is removed by irrigation ditches at the point where it exits the mountains. Land use adjacent to the river between Chatfield Reservoir and the site at Denver primarily is urban (fig. 4). Much of the basin near Denver is covered with impermeable urban materials, and numerous urban drainage pipes empty base flow and storm flow into the river. The site is representative of urban land use.

The South Platte River between Chatfield Reservoir and the fixed site is classified for recreational use (secondary contact in winter, primary contact in summer), water supply, and agricultural use. However, there is only one large surface-water diversion in this segment, the Farmer's and Gardner's Ditch, which removes about $10 \mathrm{ft}^{3} / \mathrm{s}$ from the river at the confluence with Cherry Creek for use as cooling water at a power generation plant.

Mean streamflow at South Platte River at Denver, Colorado, during the study period was $400 \mathrm{ft}^{3} / \mathrm{s}$ (table 2); annual mean streamflows were about one-half of the 20-year mean during water years 1993 and 1994, but almost twice the 20 -year mean during water year 1995 (table 3). The daily mean streamflow hydrograph for this site (fig. 4) shows that streamflow variations were common. This variability was caused by releases from Chatfield Reservoir and by short-term precipitation runoff. During rainfall runoff, water in the South Platte River changes from slightly turbid and clear to black or brown in color, and floating urban detritus is abundant. The hydrograph (fig. 4) also shows the unusually large flows that occurred during spring 1995 at the site and throughout the South Platte River Basin in response to precipitation runoff and mountain snowmelt. The maximum instantaneous flow at Denver during these large flows was $8,440 \mathrm{ft}^{3} / \mathrm{s}$ (table 3 ), which has a recurrence interval of about 8 years. The duration of the high flows also was notable; daily mean streamflow at Denver exceeded $1,000 \mathrm{ft}^{3} / \mathrm{s}$ for 71 days, compared to 1 day in water year 1993 and 1 day in water year 1994 (fig. 4).

Releases from Chatfield Reservoir during the study period (fig. 4) contributed about 40 percent of the flow at the fixed site in the summer (March through August), but only about 15 percent of the flow in the winter (September through February). About 10 percent of the flow at the site was contributed by several wastewater-treatment plants in this segment of the river, which discharge a cumulative total of about $40 \mathrm{ft}^{3} / \mathrm{s}$ of treated effluent to the river. On any given day, flow may be dominated by wastewatertreatment- plant return flows, urban base flow, or precipitation runoff (all of which are urban sources) or by reservoir releases (which contain water from upstream forested areas). However, days in which water from forested areas predominates are not common and primarily occur during spring snowmelt runoff.

Thirty-nine water-quality samples were collected during the study period at South Platte River at Denver, Colorado (fig. 4). The range in flow conditions was well represented; the minimum flow sampled was $42 \mathrm{ft}^{3} / \mathrm{s}$, and the maximum flow sampled was $5,800 \mathrm{ft}^{3} / \mathrm{s}$. Examination of the hydrograph indicates that only about five of the samples were collected when releases from Chatfield Reservoir (water from forest land use) predominated; the remaining samples represented urban land use. More than 10 samples were collected during urban precipitation runoff. 


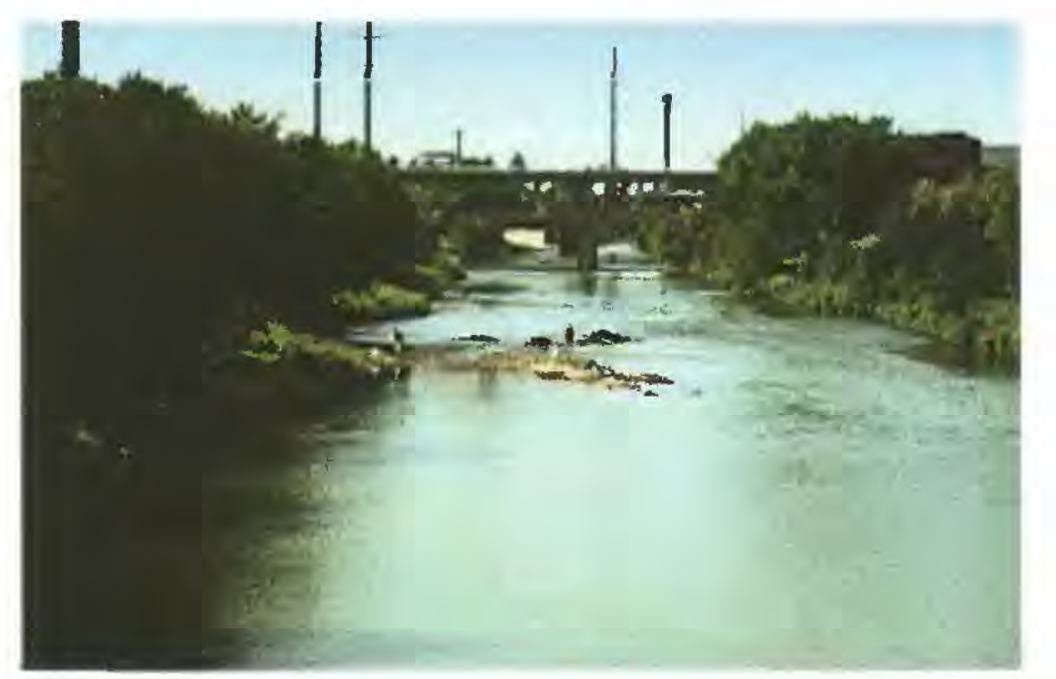

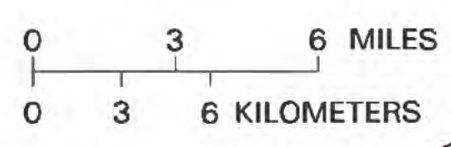

South Platte River at Denver fixed site

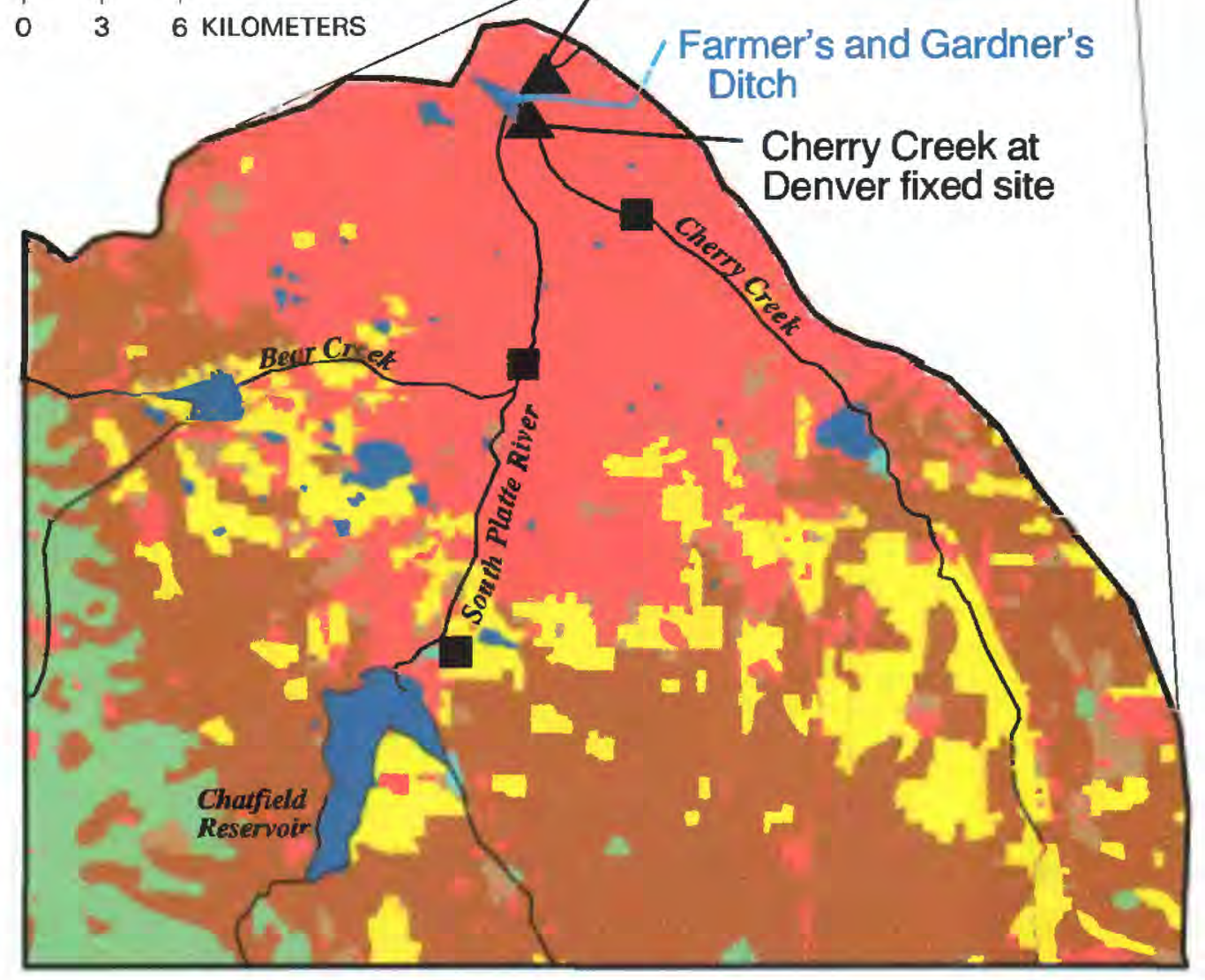

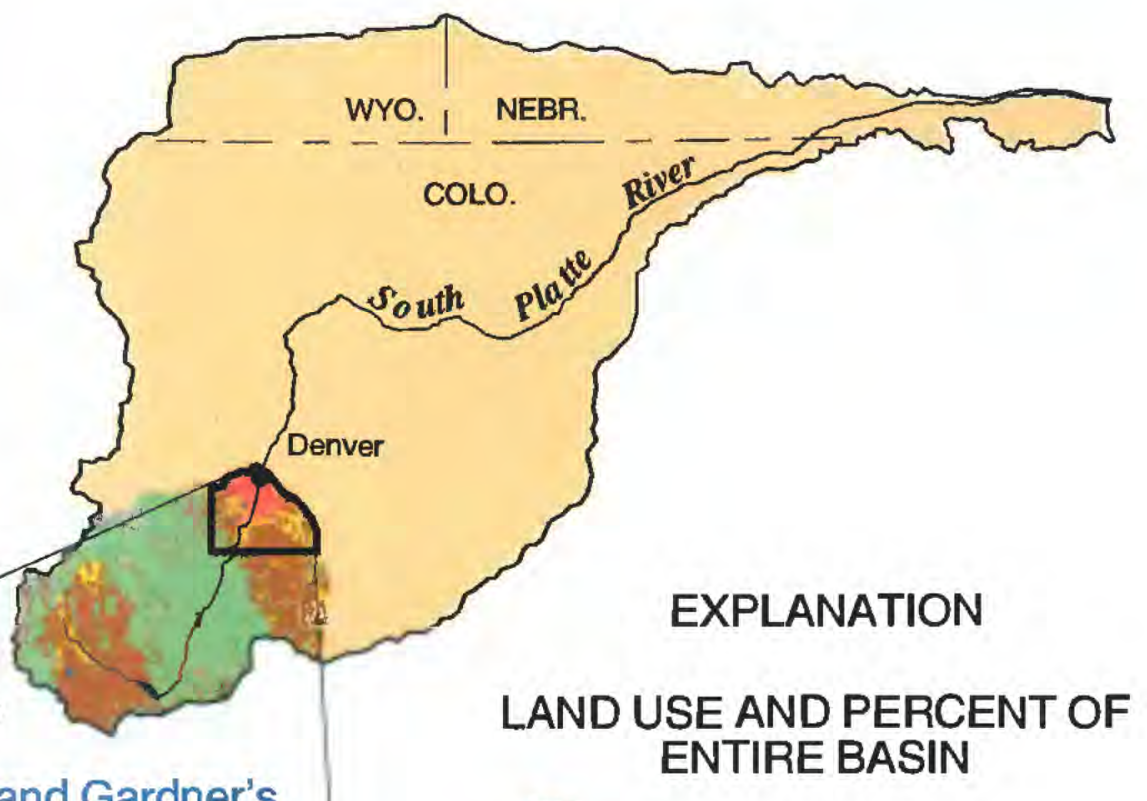

प Urban (5.3)

Agricultural (5.9)

Rangeland (34.8)

Forest (47.7)

Water (0.5)

Barren land (2.1)

Tundra (3.6)

Other (0.1)

FEATURES

- Fixed site

Wastewater-

treatment

plant

Diversion

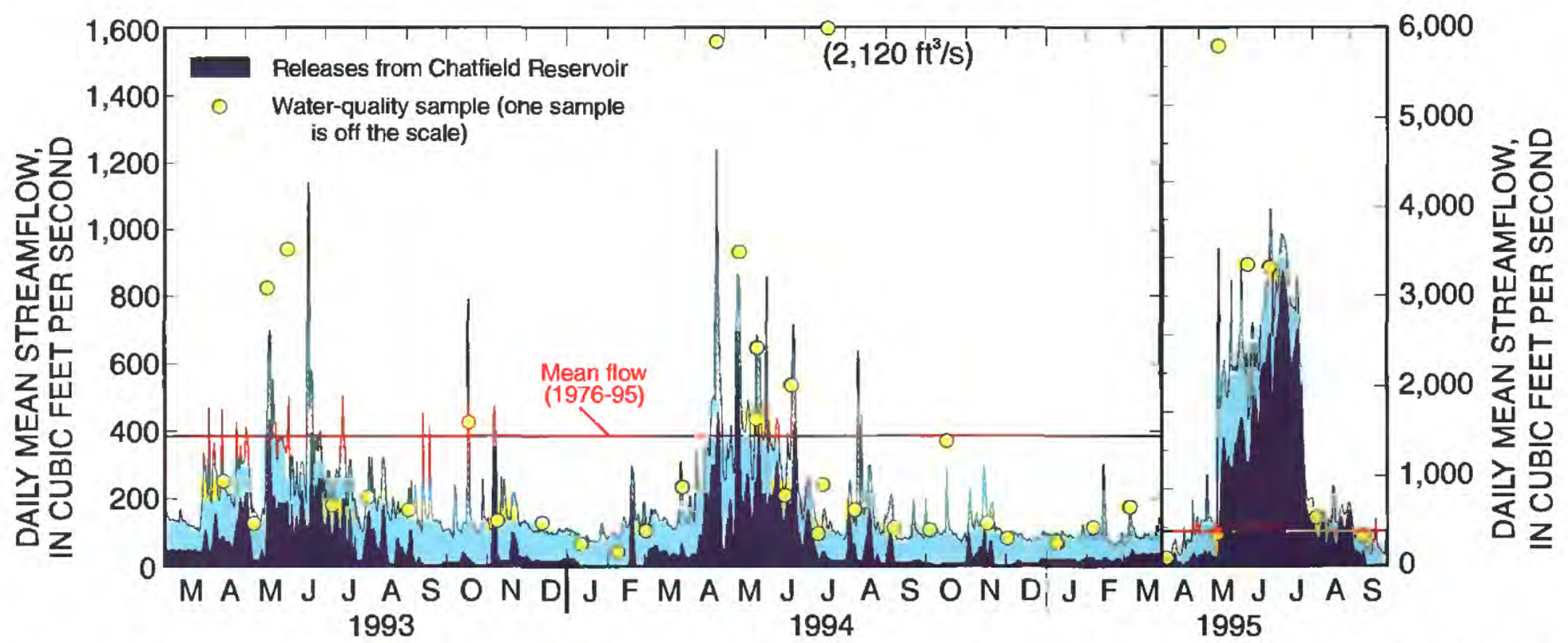

Figure 4. Map showing stream basin and land use (Fegeas and others, 1983) upstream from the fixed site, hydrograph showing streamflow at the fixed site during the study period, and photograph showing typical character of the stream at the fixed site: South Platte River at Denver, Colorado. 


\section{Clear Creek at Golden, Colorado}

Clear Creek originates on the Continental Divide west of Denver (fig. 5) and flows eastward about $55 \mathrm{mi}$ through steep-sided forested canyons to a point where it exits the mountains near Golden, Colorado. The fixed site is located directly at the mouth of the mountain canyon and is about 15 mi upstream from the confluence of Clear Creek and the South Platte River.

Upstream from the fixed site, Clear Creek flows through the Southern Rockies physiographic province. The basin is underlain by Precambrian crystalline igneous and metamorphic rocks and intersects the southern end of one of the principal mining districts in Colorado near Idaho Springs. Coarse-grained alluvium as much as $60 \mathrm{ft}$ thick overlies the bedrock in the narrow alluvial valleys.

The channel of Clear Creek has been modified in places. In mountain towns, the creek has been channelized and the banks lined with riprap. Much of the alluvium was reworked by hydraulic mining of placer gold deposits around the turn of the century. Because Clear Creek is a mountain stream, the stream gradient is the steepest of the fixed sites $(57.2 \mathrm{ft} / \mathrm{mi}$ ) (table 2), and the stream is relatively straight (sinuosity of 1.02 is the smallest among the sites). Percentage of open canopy is small at the site because of the many trees that line the banks of Clear Creek and because of the steep-sided canyon walls.

Land use in the 400- $\mathrm{mi}^{2}$ Clear Creek Basin upstream from the fixed site at Golden, Colorado, is 66.3 percent forest, 19.7 percent tundra, and 14.0 percent other land-use categories (Fegeas and others, 1983). The other land uses include mining (mine adits, tailings piles, processing mills, and minedrainage systems), a ski area, transportation (the Interstate 70 corridor is adjacent to Clear Creek for about $30 \mathrm{mi}$ ), small mountain urban areas (Idaho Springs, Central City, and Blackhawk, Colorado), and dispersed rural population. The site is representative of forest land use modified by mining and low-density urban (built-up) land use.

Clear Creek in the vicinity of the fixed site is classified for sustaining cold-water aquatic life, recre- ational use (primary contact), water supply, and agricultural use. Raw water for the Golden, Colorado, drinking-water plant is withdrawn from the creek about 1 mi upstream from the site. Two small irrigation ditches also remove water from the creek just upstream from the site, but most of the runoff derived from the basin passes the site.

Mean streamflow at Clear Creek at Golden, Colorado, during the study period was $233 \mathrm{ft}^{3} / \mathrm{s}$ (table 2); flow was similar to the 20-year mean during water year 1993, less than the 20-year mean during water year 1994, and greater than the 20-year mean during water year 1995 when localized flooding occurred in the drainage basin during snowmelt runoff (table 3). The daily mean streamflow hydrograph for this site (fig. 5) shows that Clear Creek maintains a low base flow throughout the year, which is augmented by the annual snowmelt-runoff peak that usually occurs in June. The snowmelt-runoff peak of about $2,480 \mathrm{ft}^{3} / \mathrm{s}$ during June 1995 was the largest on record (20-year record) and was caused by melting of a thick snowpack that was deposited during May, supplemented by mountain rains. Mountain rainstorms generally do not cause large increases in streamflow at the fixed site, but do cause the river to become brown in color and turbid. Base flow generally is derived from melting snow at the higher elevations and from the slow draining of snowmelt water from the soil profile and from mountain alluvial aquifers. Several small wastewater-treatment plants in the basin, which have a combined discharge of about $3 \mathrm{ft}^{3} / \mathrm{s}$, contribute to base flow, as does mine drainage from several localities in the basin (Ficklin and Smith, 1994).

Thirty-three water-quality samples were collected during the study period at Clear Creek at Golden, Colorado (fig. 5). The range in flow conditions was well represented; the minimum flow sampled was $16 \mathrm{ft}^{3} / \mathrm{s}$, and the maximum flow sampled was $1,890 \mathrm{ft}^{3} / \mathrm{s}$. Three to five samples were collected during the rise and fall of the snowmelt-runoff peak each year. The remaining samples represent base-flow conditions, except for a few samples collected during rainstorms. 

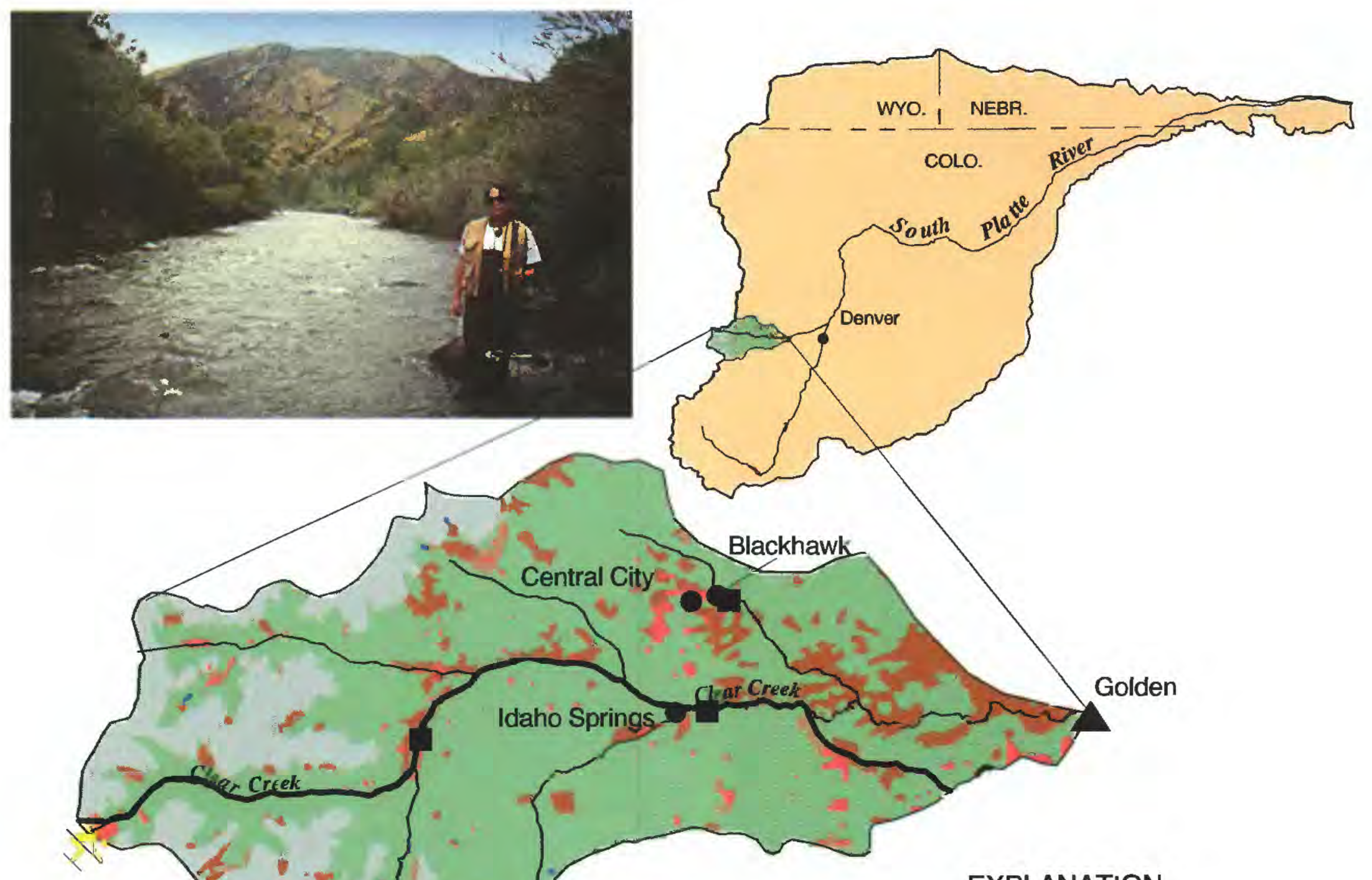

EXPLANATION

LAND USE AND PERCENT

OF ENTIRE BASIN

\section{FEATURES}

Urban (3.1)

- Interstate 1-70

Rangeland (9.6)

Forest (66.3)

$\begin{array}{llll}0 & 2 & 4 & \text { MILES } \\ 1 & 1 & 1 & \\ 0 & 2 & 4 & \text { KILOMETERS }\end{array}$

Barren land (1.1)

Tundra (19.7)

Other (0.2)

Fixed site

Wastewatertreatment plant

\section{Ski area}

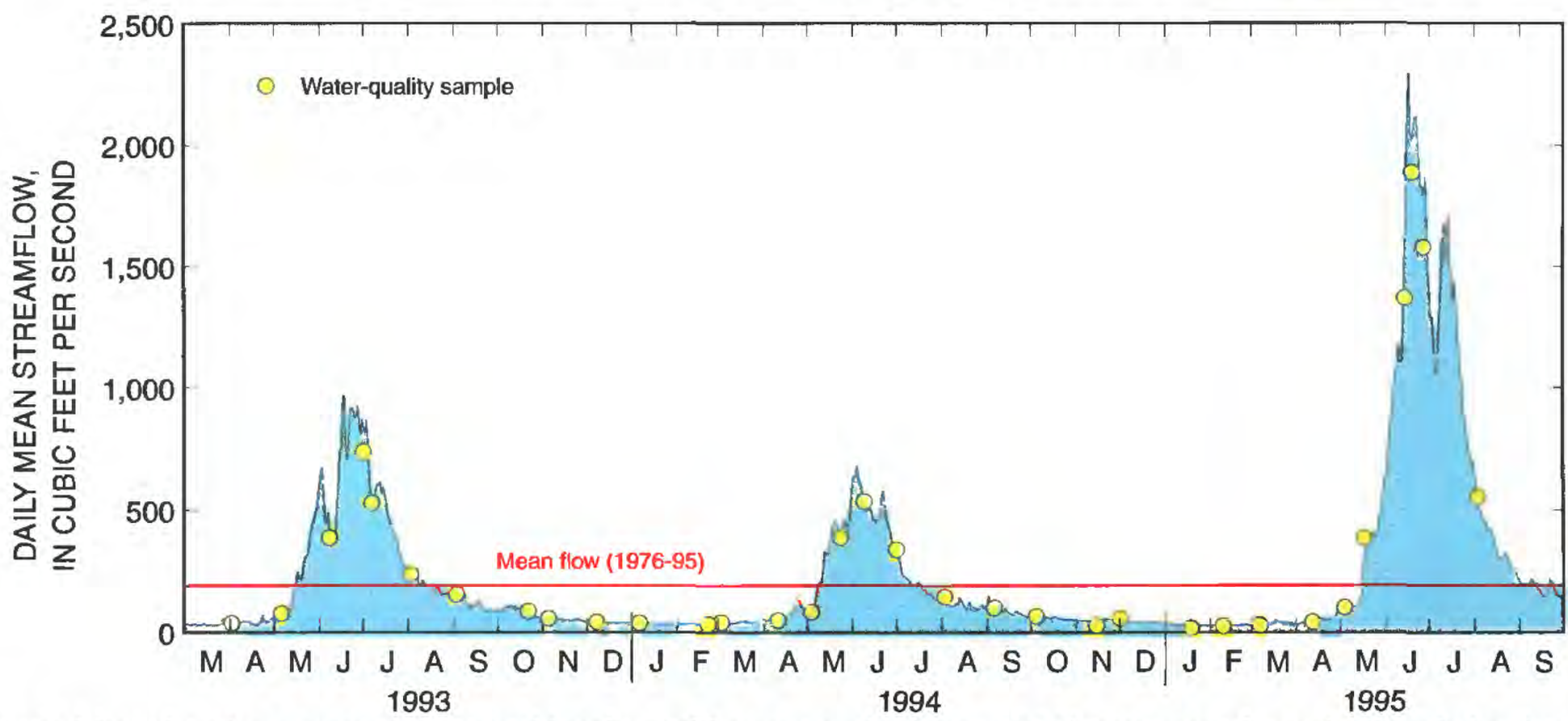

Figure 5. Map showing stream basin and land use (Fegeas and others, 1983) upstream from the fixed site, hydrograph showing streamflow at the fixed site during the study period, and photograph showing typical character of the stream at the fixed site: Clear Creek at Golden, Colorado. 


\section{South Platte River at Henderson, Colorado}

The fixed site at South Platte River at Henderson, Colorado, is located 16 river miles downstream from the site at South Platte River at Denver, Colorado (fig. 6). The river flows north in this segment through land use that is transitional from urban to agricultural. A mountain tributary (Clear Creek) and a plains tributary (Sand Creek) flow into the river in this segment.

The South Platte River in this segment flows through the Great Plains physiographic province. The segment is underlain by lower Tertiary to Upper Cretaceous sandstone and shale of the Denver Formation, but alluvial deposits as much as $40 \mathrm{ft}$ thick constitute the alluvial plain of the South Platte River, which is about 2 mi wide through this segment.

The active channel of the South Platte River is incised as much as $20 \mathrm{ft}$ below land surface in the segment from Denver to Henderson, Colorado. Some reaches are channelized and lined with riprap; other reaches are in a more natural state, and the river meanders through riparian wetlands. Large gravel pits in the alluvium are common in this segment. The stream gradient at Henderson is substantially smaller than at Denver and has a value of $6.72 \mathrm{ft} / \mathrm{mi}$ (table 2), which is representative of the river in the plains. Sinuosity at Henderson (1.13) is larger than at Denver (1.04), which also is representative of the plains environment. A large open canopy ( 80 percent) allows sunlight to reach the water surface at this site, and aquatic macrophytes, mosses, and algae are common. The habitat in this reach has been documented in detail as part of a study prepared for the Metro Wastewater Reclamation District (Camp Dresser \& McKee, Inc., 1993).

Land use in the entire 4,713- $\mathrm{mi}^{2}$ South Platte River Basin upstream from the fixed site at Henderson, Colorado, is 44.3 percent forest, 32.7 percent rangeland, 8.1 percent agricultural, 7.8 percent urban, and 7.1 percent other landuse categories (Fegeas and others, 1983). However, during most of the year, water at this site is derived from local sources rather than from headwater sources. Much of the water from headwater sources is removed by the Burlington Ditch, located about $12 \mathrm{mi}$ upstream from the fixed site; this ditch removed two-thirds of the water from the river during 1993-94, but removed a smaller proportion during the highflow year of 1995. Clear Creek and Sand Creek contribute water primarily from urban sources to the river. An important urban source of water in this segment is the principal wastewater-treatment plant for Denver, which discharges an average of $230 \mathrm{ft}^{3} / \mathrm{s}$ of effluent to the river. For these reasons, the site is representative of urban land use and is strongly affected by wastewater-treatment-plant discharges.
The South Platte River in this segment is classified for recreational use (secondary contact), water supply, and agricultural use. The city of Thornton, Colorado, transfers water from the South Platte River to a series of ponds for treatment and mixing with other sources for the town drinking-water supply; this use of the water from the South Platte River is the most downstream water-supply use. Agricultural water operations begin to have a major effect on the South Platte River in this segment. The Burlington Ditch removes about $140 \mathrm{ft}^{3} / \mathrm{s}$ of water from the river throughout the year for storage in Barr Reservoir in Adams County, Colorado, and for eventual release for irrigation use. Two additional large irrigation ditches, the Fulton and Brantner Ditches, remove about $100 \mathrm{ft}^{3} / \mathrm{s}$ from the river during the irrigation season for application to fields.

Mean streamflow at South Platte River at Henderson, Colorado, during the study period was $610 \mathrm{ft}^{3} / \mathrm{s}$ (table 2); annual mean streamflows were about one-half of the 20-year mean during water years 1993 and 1994 and almost twice the 20-year mean during water year 1995 (table 3). The daily mean streamflow hydrograph for this site (fig. 6) shows relatively uniform flows in the winter, but fluctuating flows during the rest of the year. Hourly fluctuations in flow also were substantial at this site because of the diurnal pattern of effluent discharge from the wastewater-treatment plant for Denver. Effluent discharge from the plant is smallest at 6 a.m. and increases by a factor of about 2.2 during the peak discharge, which occurs at about 1 p.m. (Todd Harris, Metro Wastewater Reclamation District, written commun., 1994). This flow pattern is repeated at Henderson and has a time lag of about 5 hours because of the time of travel between the two locations.

Thirty-one water-quality samples were collected during the study period at South Platte River at Henderson, Colorado (fig. 6). The range in flow conditions was well represented; the minimum flow sampled was $44 \mathrm{ft}^{3} / \mathrm{s}$, and the maximum flow sampled was $5,040 \mathrm{ft}^{3} / \mathrm{s}$. Discharges from the wastewater-treatment plant account for almost all the flow at Henderson, except during May, June, and July; therefore, more than two-thirds of the samples collected primarily represented wastewater-treatment-plant effluent. Sampled storms represented a broad range of urban-water sources, and samples collected during spring runoff also contained forest-derived water from Chatfield Reservoir releases. 

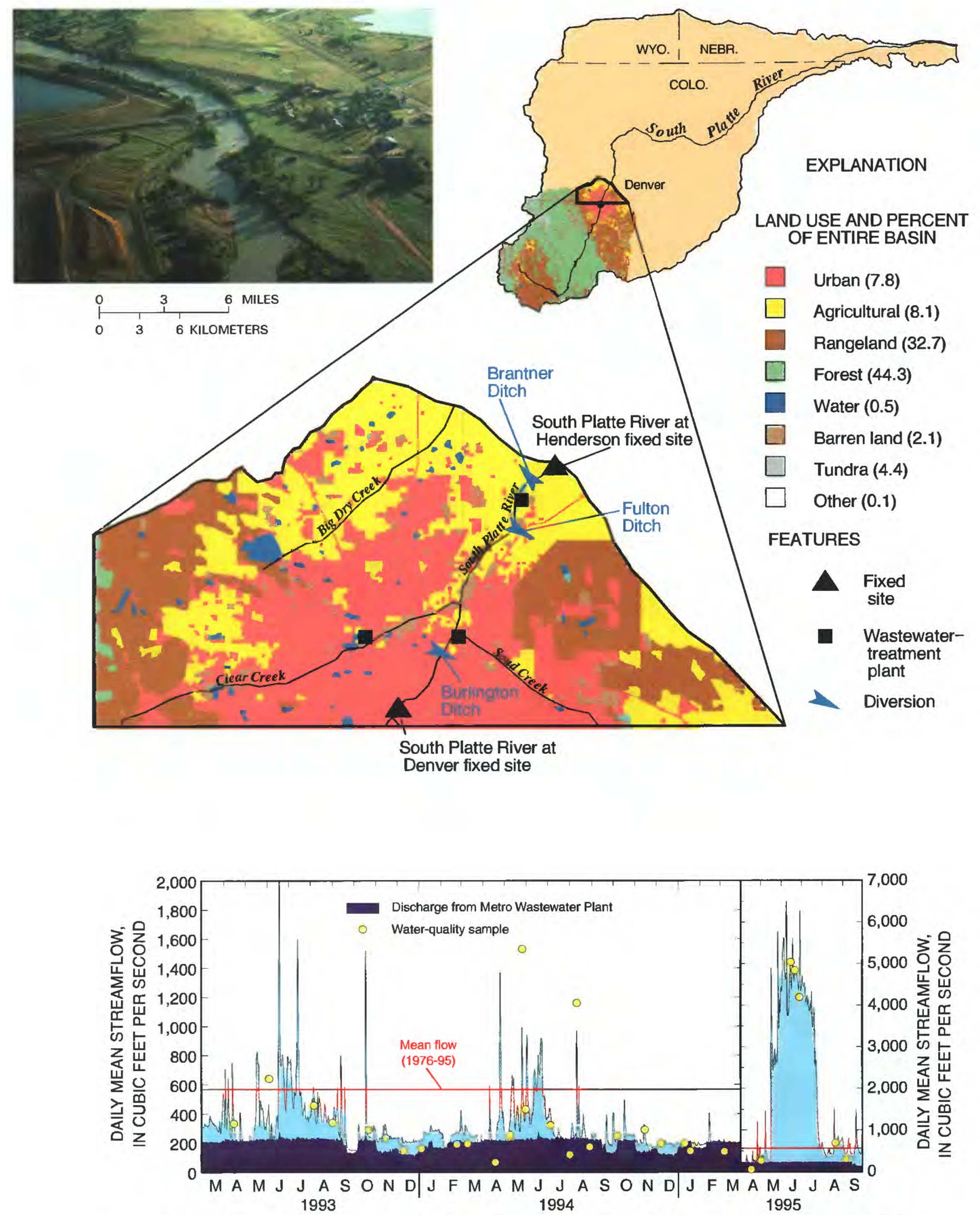

Figure 6. Map showing stream basin and land use (Fegeas and others, 1983) upstream from the fixed site, hydrograph showing streamflow at the fixed site during the study period, and photograph showing typical character of the stream at the fixed site: South Platte River at Henderson, Colorado. 


\section{St. Vrain Creek at Mouth, near Platteville, Colorado}

The headwater branches of St. Vrain Creek originate near the Continental Divide in the central western part of the South Platte River Basin (fig. 7). The branches extend eastward through alpine and forest land use for about $20 \mathrm{mi}$ to where they exit the mountains and converge near Lyons, Colorado, to form St. Vrain Creek. St. Vrain Creek then flows eastward for $15 \mathrm{mi}$ through agricultural land and the city of Longmont, Colorado, to its confluence with the South Platte River. The fixed site is located $1.3 \mathrm{mi}$ upstream from the mouth of St. Vrain Creek. Boulder Creek, which originates in the mountains and then flows through Boulder, Colorado, and agricultural lands east of Boulder, is a major tributary to St. Vrain Creek.

The St. Vrain Creek Basin is underlain by Precambrian crystalline bedrock in the mountains and Cretaceous shale and sandstone in the plains; both are covered by alluvium as much as $30 \mathrm{ft}$ thick in the valleys. The organic-rich marine Pierre Shale also crops out in the northern part of the basin.

St. Vrain Creek has been channelized in urban reaches and in a few agricultural reaches, but primarily is undisturbed and, in the vicinity of the fixed site, is a meandering stream that has a large sinuosity and moderate bank stability (table 2 ). The stream gradient at the site is the smallest of all the sites because the St. Vrain site is located in the combined flood plains of St. Vrain Creek and the South Platte River.

Land use in the entire $976-\mathrm{mi}^{2}$ St. Vrain Creek Basin upstream from the fixed site near Platteville, Colorado (fig. 7), is 43.9 percent forest, 30.5 percent agricultural, 9.4 percent rangeland, 6.4 percent urban, and 9.8 percent other land-use categories (Fegeas and others, 1983). However, water from the upper drainage basin is removed from the river and used for municipal and agricultural purposes, and water quality at the site is substantially affected by return flows from these water uses. Therefore, the site is representative of mixed urban and agricultural land use.

St. Vrain Creek in the vicinity of the fixed site is classified for recreational (secondary contact) and agricultural water use. There are about 50 irrigation ditches in the basin, which together withdraw almost $300 \mathrm{ft}^{3} / \mathrm{s}$ from St. Vrain and Boulder Creeks during the principal irrigation months (May-September). Return flows from irrigation water use are an important source of water in the lower basin; the magnitude of these return flows on St. Vrain Creek downstream from Longmont, Colorado, has been estimated to be about $4 \mathrm{ft}^{3} / \mathrm{s}$ per river mile (DuBois, 1985). Return flows from municipal water use also are an important source of water; the four principal wastewatertreatment plants in the basin discharge a total of about $40 \mathrm{ft}^{3} / \mathrm{s}$ of treated effluent [data are from U.S. Environmental Protection Agency's Permit Compliance System (PCS)].

Mean streamflow at St. Vrain Creek at mouth, near Platteville, Colorado, during the study period was $322 \mathrm{ft}^{3} / \mathrm{s}$ (table 2); annual mean streamflows were less than the 20-year mean during water years 1993 and 1994, but almost twice the 20-year mean during water year 1995 (table 3). The daily mean streamflow hydrograph for this site (fig. 7) shows that streamflow variability was small during the winter, but large during the irrigation season. The annual snowmelt-runoff peak at this site generally was of short duration because most spring flows were diverted into irrigation ditches. However, unusually large flows occurred during spring 1995 in response to precipitation runoff and mountain snowmelt. The instantaneous peak during the runoff and snowmelt was $5,190 \mathrm{ft}^{3} / \mathrm{s}$ (table 3), which has a return period of 11 years; the maximum 60 -day mean flow $\left(2,080 \mathrm{ft}^{3} / \mathrm{s}\right)$ was the largest of record.

Thirty-one water-quality samples were collected during the study period at St. Vrain Creek at mouth, near Platteville, Colorado (fig. 7). The range in flow conditions was well represented; the minimum flow sampled was $81 \mathrm{ft}^{3} / \mathrm{s}$, and the maximum flow sampled was $2,440 \mathrm{ft}^{3} / \mathrm{s}$. Because of the complex routing of water in the basin, a determination of the source of water at the fixed site on any given day might only be accomplished through the use of detailed daily flow modeling, which was beyond the scope of this study. Upstream water (from the mountains and from wastewater-treatment plants) is more likely to reach the site in the winter when the ditches are shut off; therefore, the urban effect may be more pronounced in the winter. The agricultural effect may be more pronounced during the irrigation season when local irrigation return flows provide water to the site. In general, samples are assumed to integrate the effects of urban and of agricultural land uses. 

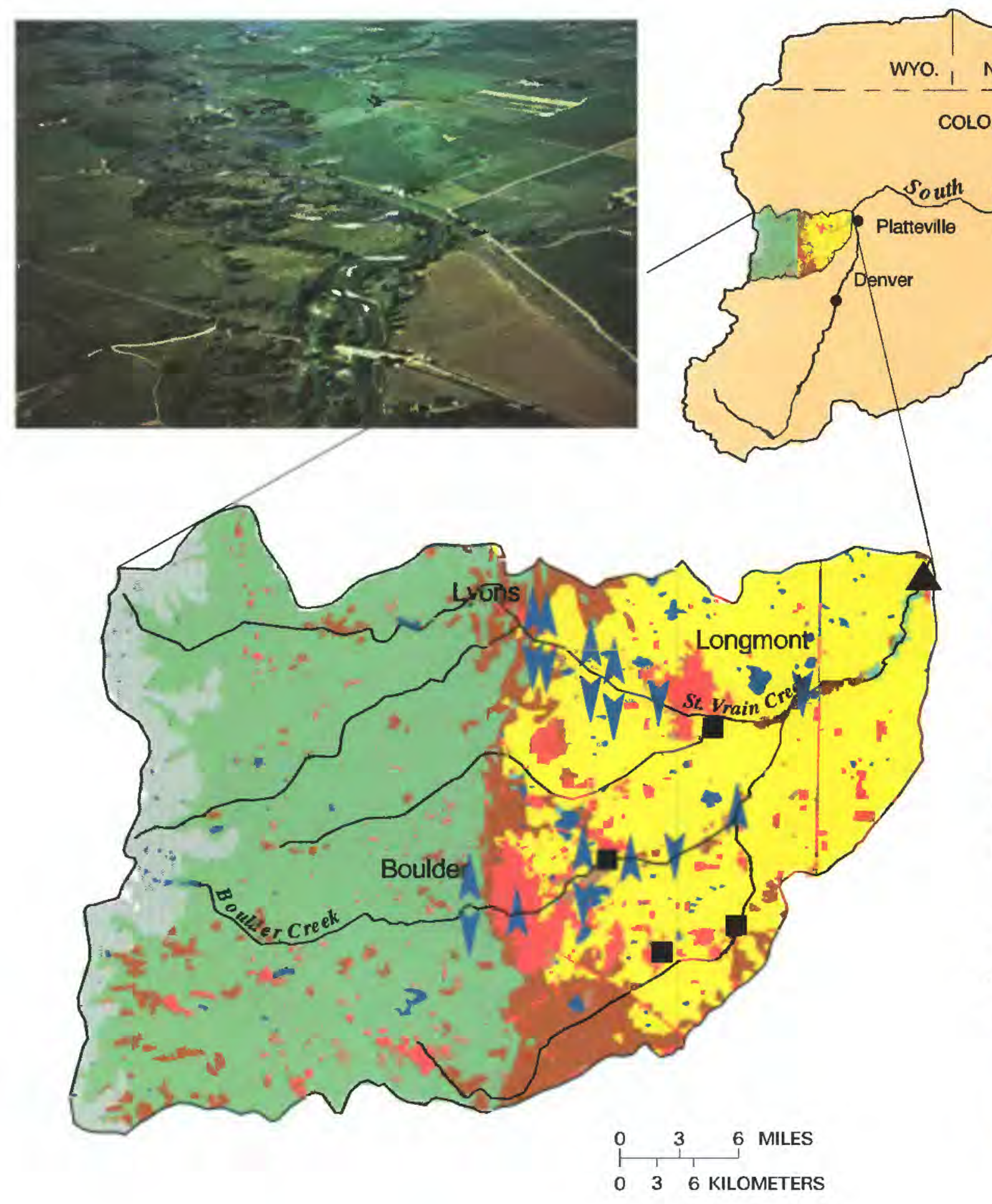

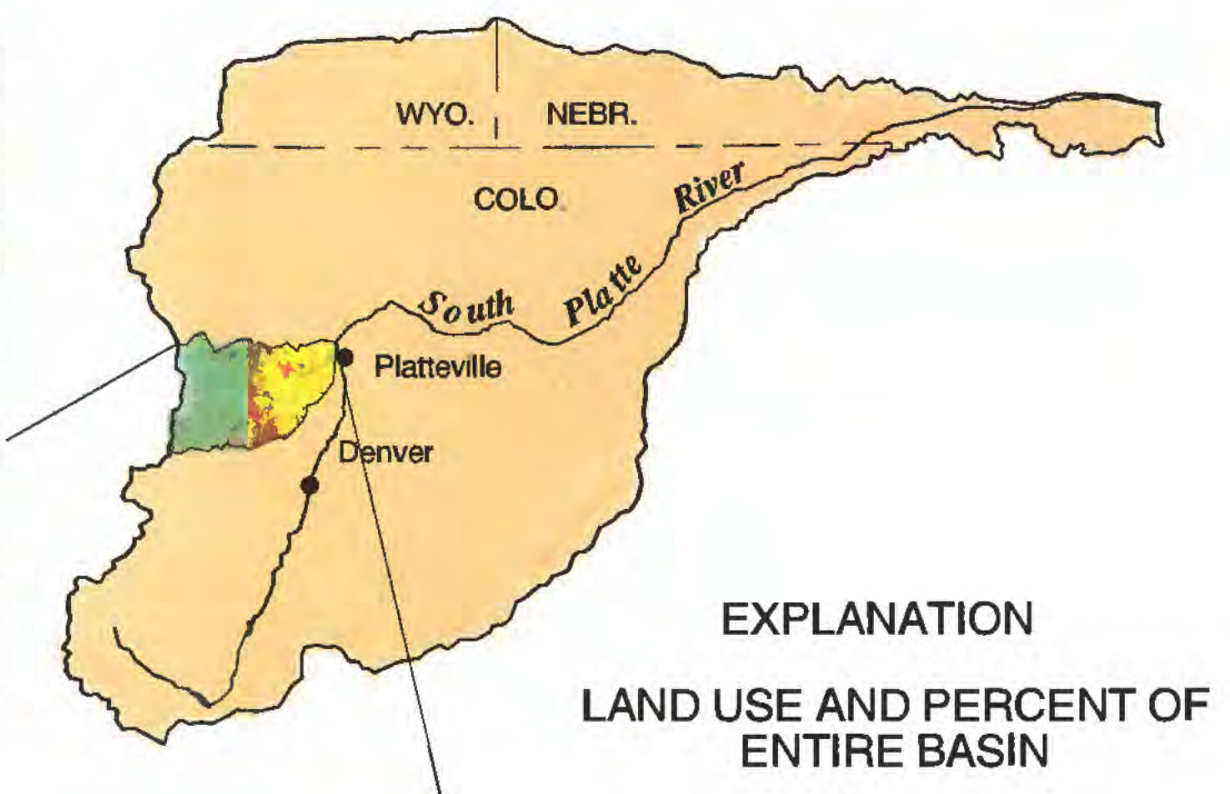

Urban (6.4)

Agricultural (30.5)

Rangeland (9.4)

Forest (43.9)

Water (1.3)

Barren land (1.3)

Tundra (6.9)

Other (0.3)

FEATURES

- Fixed site

- Wastewater-

treatment

plant

A Diversion

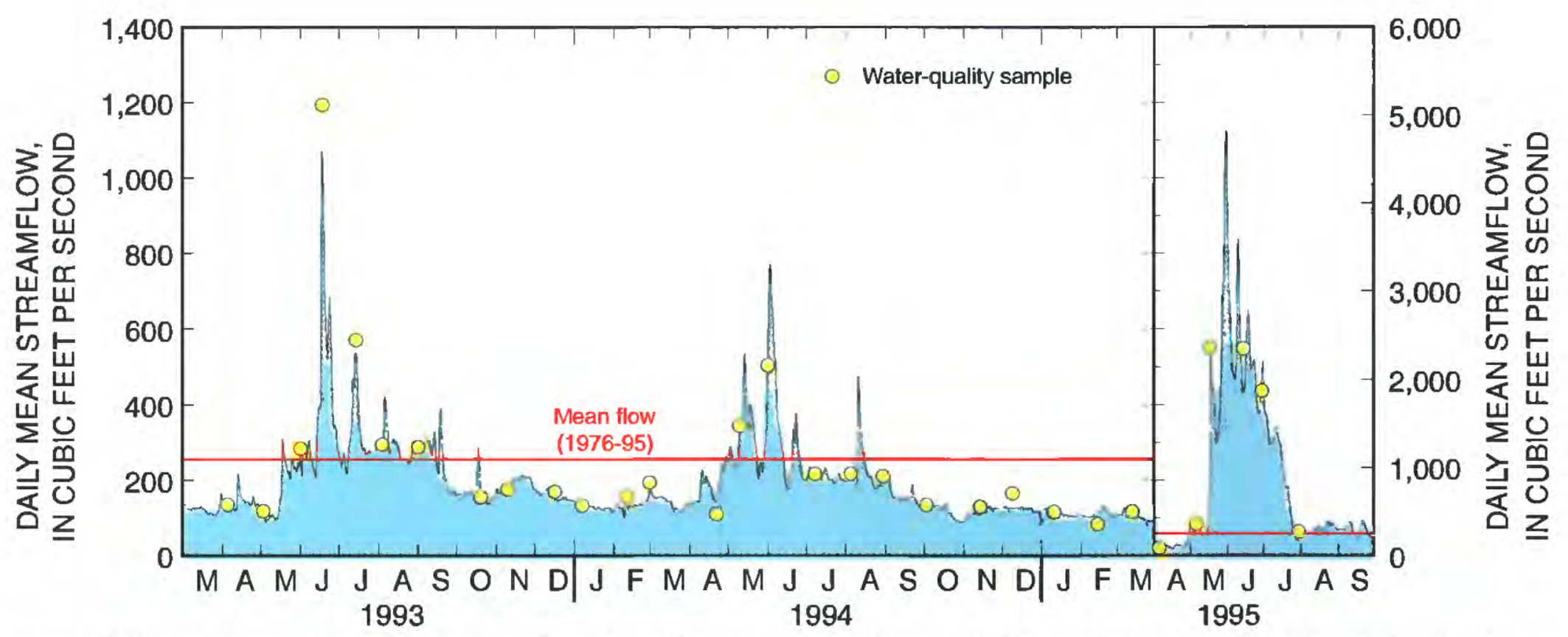

Figure 7. Map showing stream basin and land use (Fegeas and others, 1983) upstream from the fixed site, hydrograph showing streamflow at the fixed site during the study period, and photograph showing typical character of the stream at the fixed site: St. Vrain Creek at mouth, near Platteville, Colorado. 


\section{Big Thompson River below Moraine Park, near Estes Park, Colorado}

The Big Thompson River originates near the Continental Divide in Rocky Mountain National Park and flows southeast and east for $10 \mathrm{mi}$ through a steepgradient forested valley. It then meanders for $2 \mathrm{mi}$ through a wide, flat wetlands (Moraine Park) to the fixed site at the downstream end of the wetlands (fig. 8).

The Big Thompson River upstream from the fixed site flows through the Southern Rockies physiographic province. The basin is underlain by Precambrian crystalline igneous and metamorphic rocks that are overlain in the alluvial valley by reworked glacial deposits.

The river in the vicinity of the fixed site has the second largest gradient (table 2) of the fixed sites. The channel is natural and has banks $5 \mathrm{ft}$ high or less; some erosion of the banks has occurred due to trampling by elk and fishermen.

Land use in the $39-\mathrm{mi}^{2}$ Big Thompson River Basin upstream from the fixed site near Estes Park, Colorado, is 44.9 percent forest, 51.8 percent tundra, and about 3.3 percent other land-use categories (Fegeas and others, 1983). Located entirely in Rocky Mountain National Park, the basin is minimally affected by man, and the site is representative of forest land use.

The Big Thompson River in the vicinity of the fixed site is classified for sustaining cold-water aquatic life and for recreational use (secondary contact), water supply, and agricultural use. However, no water is diverted for offstream use upstream from the site.

This fixed site was established in 1995 as a result of a cooperative agreement between the USGS and the National Park Service; sampling began in January 1995, and continuous streamflow measurements began in August 1995. Therefore, the daily mean streamflow hydrograph for this site (fig. 8) is defined by the 10 instantaneous measurements made at the time of sampling. The measurements indicated that base flow during the winter was $5 \mathrm{ft}^{3} / \mathrm{s}$ or less and that spring snowmelt increased streamflow to about $500 \mathrm{ft}^{3} / \mathrm{s}$ for a few weeks, followed by a gradual streamflow recession. 

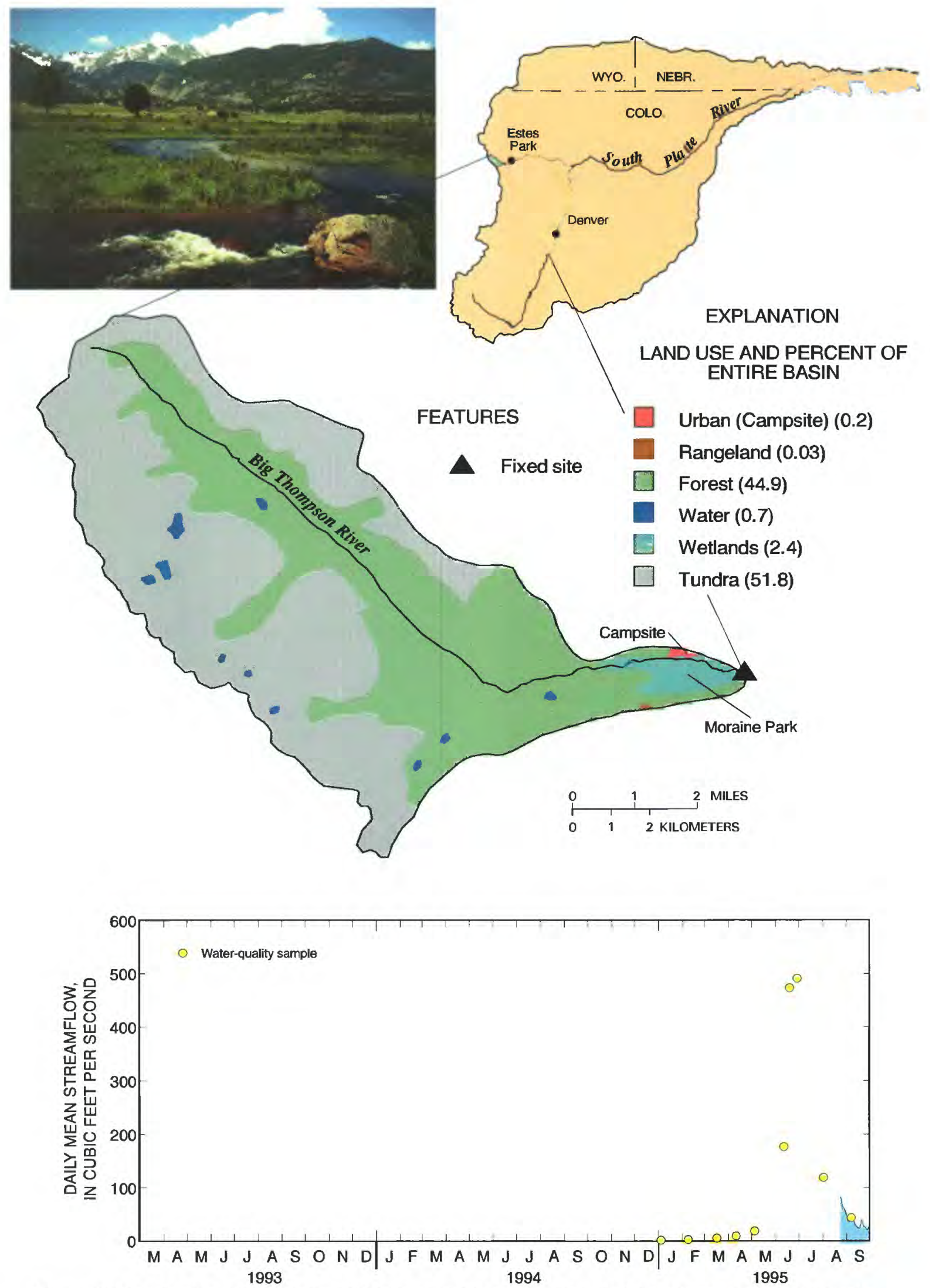

Figure 8. Map showing stream basin and land use (Fegeas and others, 1983) upstream from the fixed site, hydrograph showing streamflow at the fixed site during the study period, and photograph showing typical character of the stream at the fixed site: Big Thompson River below Moraine Park near Estes Park, Colorado. 


\section{Cache la Poudre River at Mouth of Canyon, near Fort Collins, Colorado}

The Cache la Poudre River originates in the Southern Rockies in northern Colorado along the Continental Divide and flows northward and then eastward for about $60 \mathrm{mi}$ through forested land to a point about $9 \mathrm{mi}$ northwest of Fort Collins, Colorado, where it exits the mountains and enters the plains (fig. 9); the fixed site is located at this point at the mouth of the canyon. A major tributary, the North Fork Cache la Poudre, flows into the Cache la Poudre River about $3 \mathrm{mi}$ upstream from the site and contributes water from rangeland and forest lands.

Upstream from the fixed site, the Cache la Poudre River flows through the Southern Rockies physiographic province; the North Fork Cache la Poudre also primarily flows through the Southern Rockies Province, but its lower reaches also flow through the Great Plains Province. In the mountains, the basin is underlain by Precambrian crystalline igneous and metamorphic rocks; the part of the North Fork drainage in the plains is underlain by sedimentary sandstone and shale of Triassic to Cretaceous age.

The river channel predominantly is in a natural state with a meandering morphology, although riprap has been used in places to stabilize the banks, especially where the highway is in close proximity to the river. Sinuosity and gradient (table 2) are among the largest of the fixed sites. Substrate materials are cobble-sized, and bedrock often crops out in the channel. Trees along the banks and high bedrock valley walls create less open canopy than at the plains sites. A more detailed description of the habitat of the Cache la Poudre River is presented in Wentz (1974).

Land use in the 1,056- $\mathrm{mi}^{2}$ Cache la Poudre River Basin upstream from the fixed site near Fort Collins, Colorado, is 65.5 percent forest, 27.8 percent rangeland, and 6.7 percent other land-use categories (Fegeas and others, 1983). Most of the basin is in the Roosevelt-Arapahoe National Forest, and the southwestern parts are in Rocky Mountain National Park. The Cache la Poudre River has been designated a Wild and Scenic River and is managed as a recreational river through most of its length upstream from the site and as a Wild River in the upper reaches. A State highway parallels the river in the basin. Picnic areas, campgrounds, and isolated private tracts with cabins are located along the river. The river is a popular site for private and commercial whitewater rafting during spring runoff. The site is representative of forest land use with some anthropogenic effects.

The Cache la Poudre River in the vicinity of the fixed site is classified for recreational use (noncontact), water supply, and agricultural water use. Water at the site is derived from the entire basin, although some water is removed from the river upstream from the site for irrigation (about $100 \mathrm{ft}^{3} / \mathrm{s}$ ) and water supply (about $20 \mathrm{ft}^{3} / \mathrm{s}$ ). Water also is removed from the North Fork Cache la Poudre upstream from the site. About $50 \mathrm{ft}^{3} / \mathrm{s}$ of water is imported into the basin from the North Platte and Colorado River drainages, but the imported water is derived from a similar forest land use.

Mean streamflow at Cache la Poudre River at mouth of canyon, near Fort Collins, Colorado, during the study period was $366 \mathrm{ft}^{3} / \mathrm{s}$ (table 2); annual mean streamflows were similar to the 20-year mean during water year 1993, substantially less than the 20-year mean during water year 1994, and slightly greater than the 20-year mean during water year 1995 (table 3). The daily mean streamflow hydrograph for this fixed site (fig. 9) shows that streamflow did not vary much during base flow from September through April. Snowmelt runoff increased flow substantially from May through August. During the snowmelt-runoff period, a diurnal fluctuation in flow was recorded: maximum flow occurred at about 5 a.m. when snowmelt from the previous day reached the site, and minimum flow occurred at about 10 p.m. During snowmelt, the diurnal variation in the stage of the river was as much as $1 \mathrm{ft}$.

Thirty-two water-quality samples were collected at the fixed site during the study period; the minimum flow sampled was $14 \mathrm{ft}^{3} / \mathrm{s}$, and the maximum flow sampled was $3,100 \mathrm{ft}^{3} / \mathrm{s}$. Both base flow and snowmelt-runoff conditions were well represented. About five samples were collected across the snowmelt-runoff peak each year. 


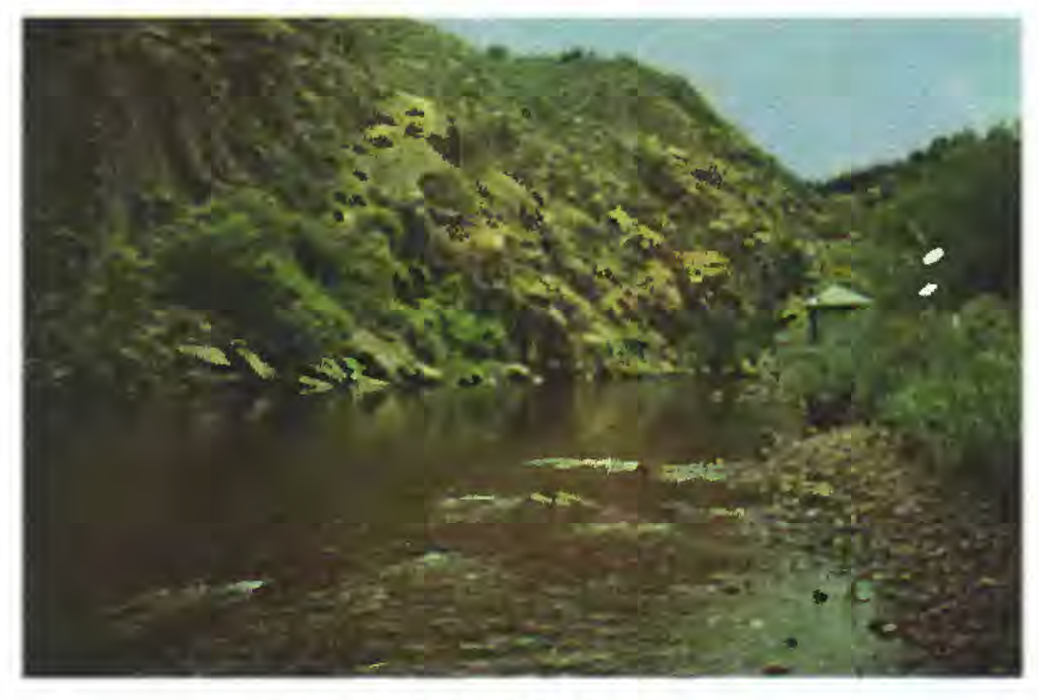

EXPLANATION

LAND USE AND PERCENT OF ENTIRE BASIN

$\square$ Urban (0.3)

Agricultural (1.0)

Rangeland (27.8)

Forest (65.5)

Water (0.3)

Wetlands (0.3)

Tundra $(4.8)$

\section{FEATURES}

assoss National park boundary National forest boundary

- Fixed site

- Diversion
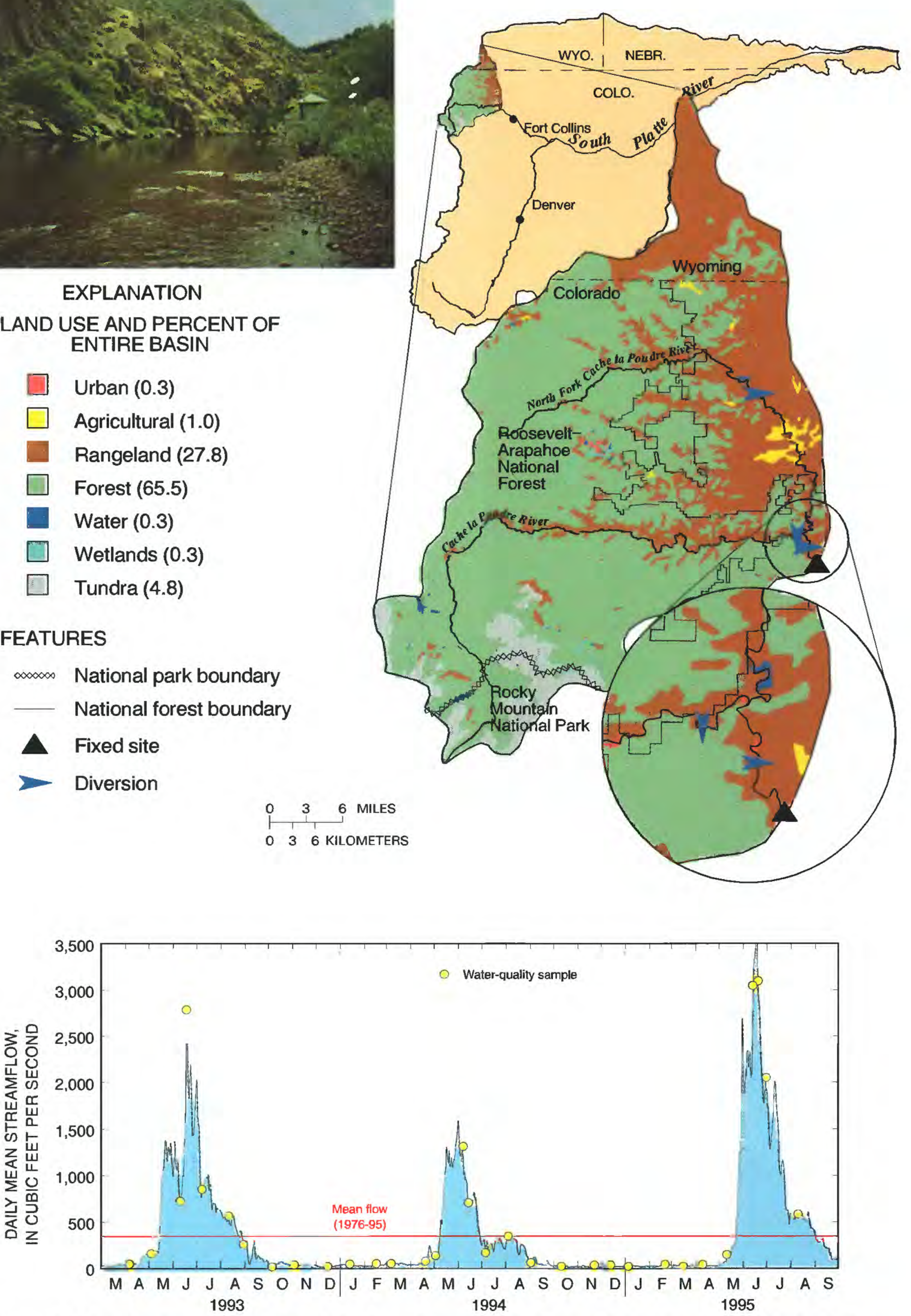

Figure 9. Map showing stream basin and land use (Fegeas and others, 1983) upstream from the fixed site, hydrograph showing streamflow at the fixed site during the study period, and photograph showing typical character of the stream at the fixed site: Cache la Poudre River at mouth of canyon, near Fort Collins, Colorado. 


\section{Lonetree Creek at Carr, Colorado}

Lonetree Creek originates in the high plains region of southeastern Wyoming, flows east to the vicinity of Cheyenne, Wyoming, and then flows southeast through rangeland into Weld County, Colorado (fig. 10). The fixed site at Carr, Colorado, is about 10 river miles south of the Wyoming-Colorado State line.

Lonetree Creek upstream from the fixed site flows through the Great Plains physiographic province. The plains are at a high elevation (about 6,000 ft) in this vicinity, and the upper part of the basin is adjacent to the gangplank, a gently sloping erosional remnant of the ancient high plains. The basin is underlain primarily by Tertiary sandstones.

The channel of Lonetree Creek is meandering and has a large sinuosity and gradient (table 2). Bank stability is large, and the predominant substrate is gravel and cobble. Percent of open canopy is small because of the many trees along the banks and because the channel commonly is incised into the surrounding plain.

Lonetree Creek in the vicinity of the fixed site is classified for recreational (noncontact) and agricultural use. Occasional ditches remove water to irrigate alluvial hay fields, but the primary use of the stream is to provide water for cattle, either in the natural channel or in ponds formed by damming the stream.

Land use in the 167-mi ${ }^{2}$ Lonetree Creek Basin upstream from the fixed site at Carr, Colorado, is 95.6 percent rangeland and 4.4 percent other land-use categories (Fegeas and others, 1983). Cattle range throughout the basin, but are concentrated in the valleys where hay is more abundant and where there is direct access to the stream for drinking water. The basin is a transportation corridor for several highways and a railway line, which might affect water quality during periods of intense precipitation. The fixed site is representative of rangeland use.

Mean streamflow at Lonetree Creek at Carr, Colorado, during the study period was $0.5 \mathrm{ft}^{3} / \mathrm{s}$ (table 2); historical streamflow data at this site were not available. Annual precipitation in the basin averages only 12 in., and runoff is low. Flow in the stream primarily is dependent on interactions with the aquifer; base flow is maintained in some reaches, whereas other reaches are dry. At the fixed site, where the channel is incised about $15 \mathrm{ft}$ below land surface, base flow was maintained throughout the year (fig. 10). Base flows were smallest in summer, probably due to uptake of water by phreatophytes, and were larger in fall and winter. Flow in the stream increased in response to precipitation, although the largest daily mean streamflow during the study period was only $5 \mathrm{ft}^{3} / \mathrm{s}$. Streamflow increases during precipitation probably initially were due to overland flow and increased ground-water inflow, followed by a rapid decrease in overland flow and a gradual recession in ground-water inflow as the soils drained. Twenty-eight samples were collected at the site during the study period. Streamflow during sampling ranged from 0.09 to $1.6 \mathrm{ft}^{3} / \mathrm{s}$; rainfall peaks were not well represented because runoff events were rare and generally lasted only a few hours. 

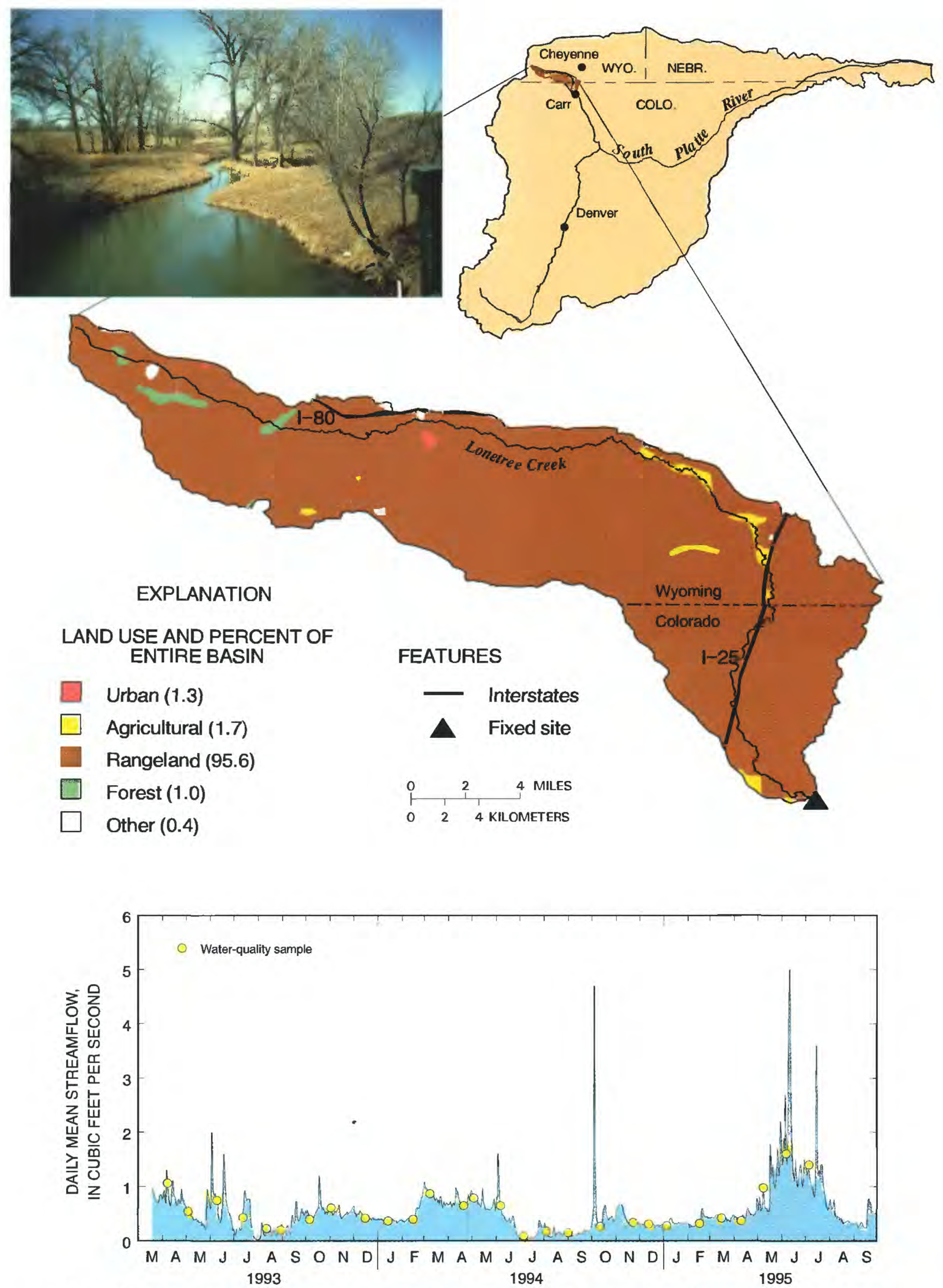

Figure 10. Map showing stream basin and land use (Fegeas and others, 1983) upstream from the fixed site, hydrograph showing streamflow at the fixed site during the study period, and photograph showing typical character of the stream at the fixed site: Lonetree Creek at Carr, Colorado. 


\section{Lonetree Creek near Greeley, Colorado}

Lonetree Creek originates in the high plains region of southeastern Wyoming, flows east to the vicinity of Cheyenne, Wyoming, and then flows southeast through rangeland to the fixed site at Carr, Colorado. The stream then flows south through rangeland, dryland farming, and irrigated agricultural land in Weld County, Colorado, to its confluence with the South Platte River near Greeley, Colorado (fig. 11). The fixed site near Greeley, Colorado, is located about $40 \mathrm{mi}$ downstream from the site at Carr and about $1 \mathrm{mi}$ upstream from the confluence of Lonetree Creek and the South Platte River.

Lonetree Creek flows through the Great Plains physiographic province. The basin primarily is underlain by Tertiary and Upper Cretaceous sandstones.

Although the channel of Lonetree Creek exists in a natural riparian condition in some reaches, many reaches in the lower basin have been altered. In places. the stream has been routed into ditches, and elsewhere, natural vegetation has been removed and the channel cuts through cultivated fields. The stream gradient (table 2) is relatively large, but comparable to the gradient at other fixed sites on tributary streams. Sinuosity (1.36) is the second largest of all the fixed sites. The predominant substrate is sand, and bank stability is smallest of the sites located on tributaries. There is 100 percent open canopy at the site.

Land use in the $567-\mathrm{mi}^{2}$ Lonetree Creek Basin upstream from the fixed site near Greeley, Colorado, is 63.7 percent rangeland, 33.6 percent agricultural, and 2.7 percent other land uses (Fegeas and others, 1983). However, several irrigation ditches transect the basin between the site at Carr and the site near Greeley, and the character of the basin changes from range-

land/dryland farming to irrigated agricultural land. Field measurements indicated that water at the site predominantly was derived from irrigation ditches and irrigation return flows; therefore, the contributing drainage area for the site is the $76-\mathrm{mi}^{2}$ area located downstream from the irrigation ditches that transect the basin. Land use in the contributing drainage area is 66 percent irrigated cropland, 10 percent field and road borders, 9 percent water and perennial wetlands, 8 percent nonagricultural grass and bare ground, 2 percent rangeland, 2 percent dryland wheat, and 3 percent other, as determined from Landsat imagery (Wagner, 1992). Corn (53 percent of irrigated crop acreage), alfalfa (26 percent), sugar beets ( 8 percent), pinto beans ( 6 percent), onions ( 3 percent), and carrots ( 1 percent) were the major crops in 1993
(Wagner, 1992). Numerous small feedlots for cattle are located in the basin, some of them adjacent to the stream channel. The site is representative of agricultural land use.

Lonetree Creek in the vicinity of the fixed site is classified for recreational (noncontact) and agricultural use, but the stream primarily is used as a conduit for imported irrigation water. Several large irrigation ditches import water into the basin from the Cache la Poudre River. This water is distributed to fields through numerous laterals and farm distribution systems and also is stored in small irrigation reservoirs. Ground water also is pumped in the basin for supplemental irrigation. Irrigation return flows reach the stream as direct surface return flows from fields adjacent to the stream and as ground-water return flows from the alluvial aquifer. Several small ditches remove water from Lonetree Creek in its lower reaches.

Mean streamflow at Lonetree Creek near Greeley, Colorado, during the study period was $15 \mathrm{ft}^{3} / \mathrm{s}$ (table 2); historical streamflow data were not available for this fixed site. From October to April, daily mean streamflow varied little (fig. 11) and gradually decreased, which indicated a draining alluvial aquifer as the principal source of water. During the irrigation season (May to September), streamflow varied substantially in response to irrigation-management practices. For example, a brief streamflow peak in early May 1993 was caused by pre-irrigation season flushing of one of the canal systems; and weekly flow variations during July through September 1993 were caused by a weekday-weekend pattern in irrigation water use prescribed by many of the growers in the basin. Occasional peaks in streamflow were caused by rainfall runoff. Large streamflows during spring and summer of 1995 were due to unusually large precipitation volume during that period and by the surplus of water throughout the basin, which was available for irrigation diversions.

Thirty-five water-quality samples were collected during the study period at Lonetree Creek near Greeley, Colorado (fig. 11); the minimum flow sampled was $2.2 \mathrm{ft}^{3} / \mathrm{s}$, and the maximum flow sampled was $166 \mathrm{ft}^{3} / \mathrm{s}$. The range in flow conditions was well represented. Nonirrigation-season samples represented ground-water irrigation return flows. Irrigation-season samples represented a variety of possible irrigation-water sources that were too complex to be differentiated. Several highflow samples represented precipitation runoff from agricultural lands. 

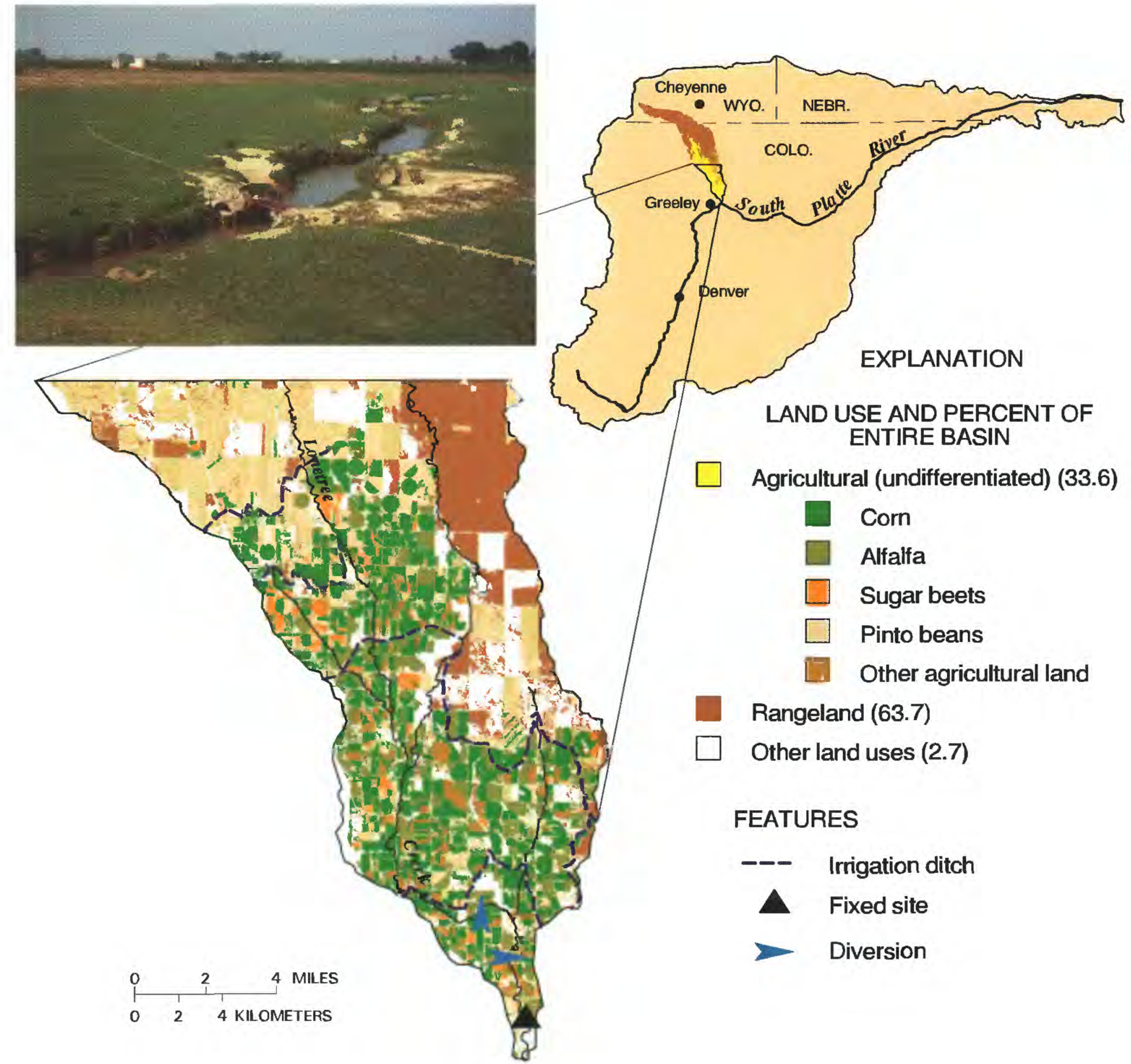

Agricultural (undifferentiated) (33.6)

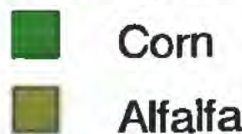

$\square$ Sugar beets

$\square$ Pinto beans

Other agricultural land

Rangeland (63.7)

Other land uses (2.7)

FEATURES

Irrigation ditch

- Fixed site

- Diversion

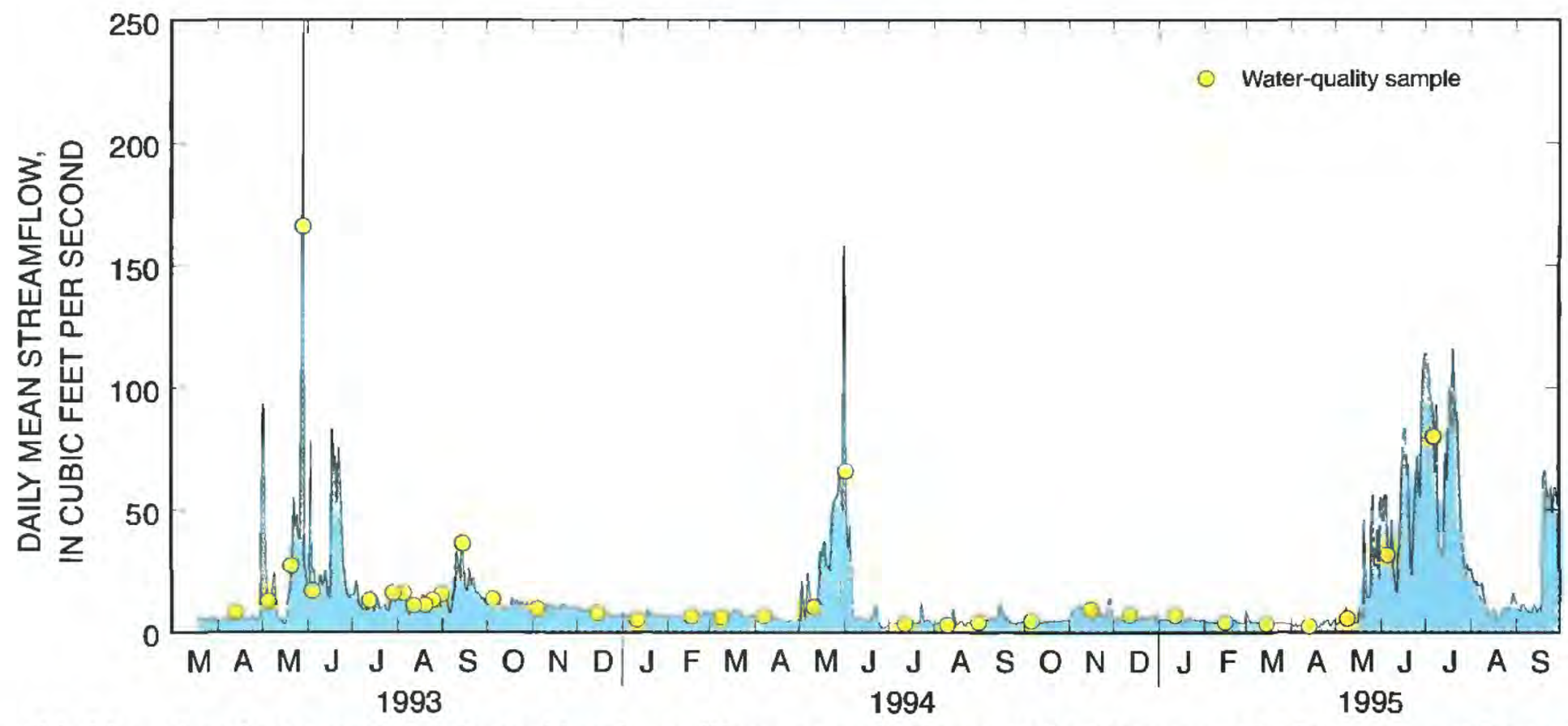

Figure 11. Map showing stream basin and land use (Fegeas and others, 1983; Wagner, 1992) upstream from the fixed site, hydrograph showing streamflow at the fixed site during the study period, and photograph showing typical character of the stream at the fixed site: Lonetree Creek near Greeley, Colorado. 


\section{South Platte River near Kersey, Colorado}

The fixed site at South Platte River near Kersey, Colorado, is located 56 river miles downstream from the site at South Platte River at Henderson, Colorado (fig. 12). The river flows north through this segment through predominantly agricultural lands. The three principal tributaries to the South Platte River (St. Vrain Creek, Big Thompson River, and Cache la Poudre River) flow into the river in this segment; largely due to water added by these tributaries, streamflow in the South Platte River generally reaches a maximum at the Kersey site throughout the year. Water from these tributaries consists of native water and water imported from the Colorado River Basin by transmountain diversion structures of the Colorado-Big Thompson Project.

The South Platte River in this segment flows through the Great Plains physiographic province. The segment is underlain by Upper Cretaceous sandstone, but alluvial deposits as much as $150 \mathrm{ft}$ thick cover the alluvial valley of the South Platte River, which is 3 to $5 \mathrm{mi}$ wide through this segment.

The active channel of the South Platte River is incised as much as $20 \mathrm{ft}$ below land surface in the segment from Henderson to Kersey, Colorado. Some reaches are channelized and are lined with riprap; other reaches are in a more natural state and the river meanders through riparian wetlands. A riparian buffer zone that has cottonwood trees where cattle often graze usually separates the river from nearby irrigated fields. The stream gradient near Kersey $(6.19 \mathrm{ft} / \mathrm{mi})$ is the smallest gradient for the fixed sites on the South Platte River, and sinuosity also is small (table 2). Bank stability is the smallest of all the sites.

Land use in the entire $9,598-\mathrm{mi}^{2}$ South Platte River Basin upstream from the fixed site near Kersey, Colorado, is 38.2 percent forest, 29.0 percent rangeland, 21.1 percent agricultural, 5.5 percent urban, and 6.2 percent other land-use categories (Fegeas and others, 1983). However, characterization of effective land use for this site is complex because water at this site has four principal sources originating in different land uses, and the relative contributions from these four sources varies. The first source is wastewater-treatment-plant effluent from urban areas, which can total as much as $330 \mathrm{ft}^{3} / \mathrm{s}$; about 70 percent of this quantity comes from the principal wastewater-treatment plant in Denver, Colorado, and 30 percent comes from about 40 small- to mediumsize wastewater-treatment plants located on tributary streams. The second source is relatively pristine runoff and base-flow water derived from forest land use in the mountains; the water flows through the drainage network when ditches are shut off or when flow volumes are large during spring snowmelt runoff. The third source of water is ground-water irrigation return flows from agricultural lands, which are largest during and just after the irrigation season. The fourth source is urban and agricultural runoff during rainfall runoff in the plains. Because of these combined effects, the site near Kersey primarily represents urban and agricultural land use. The relative importance of each of these sources represented in any given water sample can be difficult to estimate, especially during the irrigation season.

The South Platte River in the vicinity of the fixed site is classified for recreation (noncontact) and agricultural use. There are about 100 ditches that remove water from the three principal tributaries to the South Platte River, and there are 10 major ditches that remove water directly from the South Platte River between Henderson and Kersey, Colorado. Most of these ditches only operate during the irrigation season to deliver water to fields, so the river becomes more of a flow-through system in the nonirrigation season. Water pumpage from the alluvial aquifer is a substantial source of supplemental irrigation water.

Mean streamflow at South Platte River near Kersey, Colorado, during the study period was $1,330 \mathrm{ft}^{3} / \mathrm{s}$ (table 2); annual mean streamflows were about one-half of the 20 -year mean during water years 1993 and 1994 and almost twice the 20-year mean during water year 1995 (table 3 ). The daily mean streamflow hydrograph for this fixed site (fig. 12) shows that streamflow generally was largest and most uniform during the winter when irrigation ditches were shut off. During the dry years of 1993 and 1994, streamflow decreased during the irrigation season (April through August) - a large part of the available spring snowmelt runoff was diverted from the river for irrigation use. The general decrease in flow during the irrigation season was interrupted by temporary increases due to rainfall and changes in ditch operations. During the wet year of 1995, however, the abundance of water in excess of demand and in excess of the carrying capacity of diversion structures caused a large streamflow peak from May through July. The instantaneous flow peak near Kersey during this period was $22,900 \mathrm{ft}^{3} / \mathrm{s}$, which has a return period of 23 years (table 3). Daily mean streamflow near Kersey in 1995 exceeded $5,000 \mathrm{ft}^{3} / \mathrm{s}$ for 66 consecutive days, compared to zero days in 1993 and 1994; this was the second largest sustained period of flow near Kersey during the 90 years of record.

Thirty-four water-quality samples were collected during the study period at South Platte River near Kersey, Colorado (fig. 12). The range in flow conditions was well represented; the minimum flow sampled was $166 \mathrm{ft}^{3} / \mathrm{s}$, and the maximum flow sampled was $19,000 \mathrm{ft}^{3} / \mathrm{s}$. All samples represented the combined effects of urban and agricultural land use. 

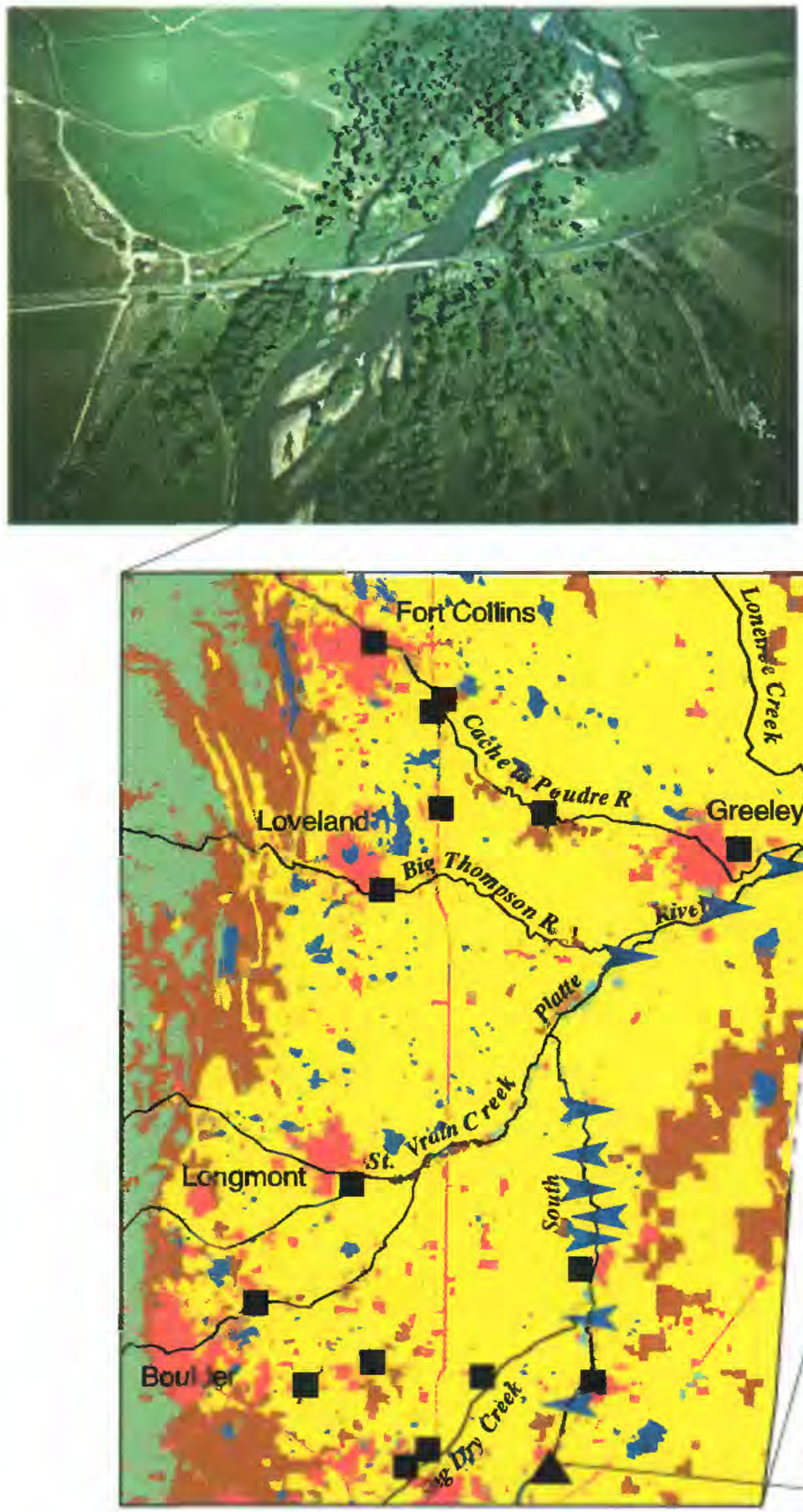

South Platte River at
Henderson fixed site

$0 \quad 36$ KILOMETERS

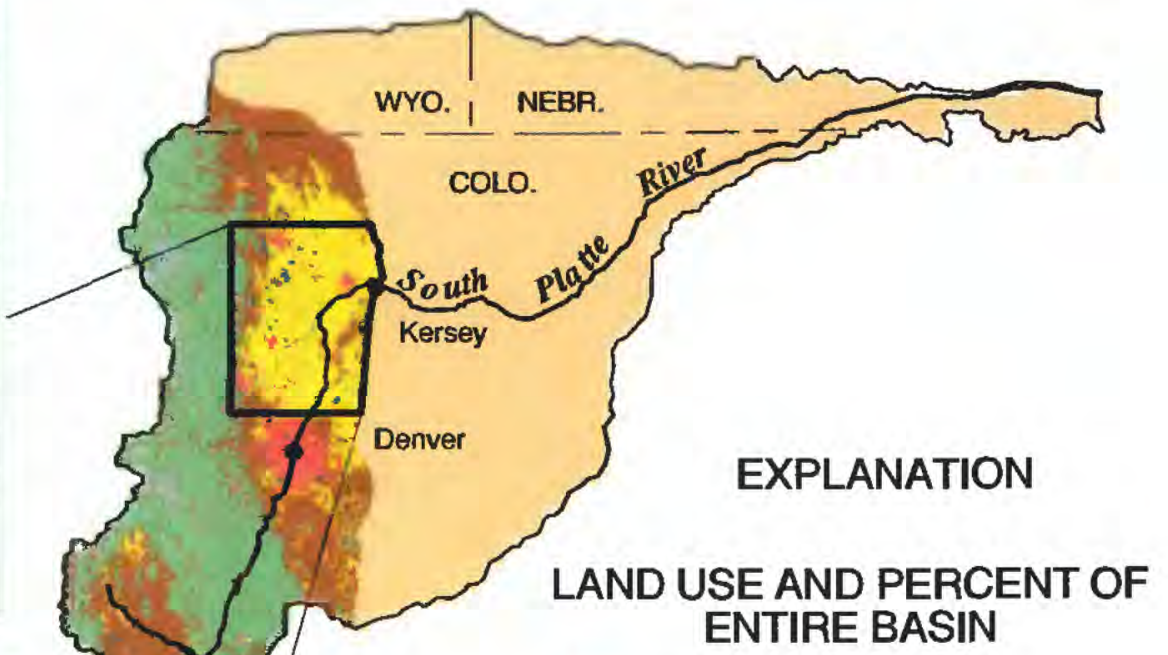

Urban (5.5)

Agricultural (21.1)

Rangeland (29.0)

Forest (38.2)

Water (0.7)

South Platte River near

Kersey fixed site

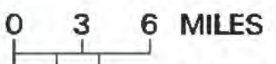

treatment

plant

- Diversion from

South Platte River

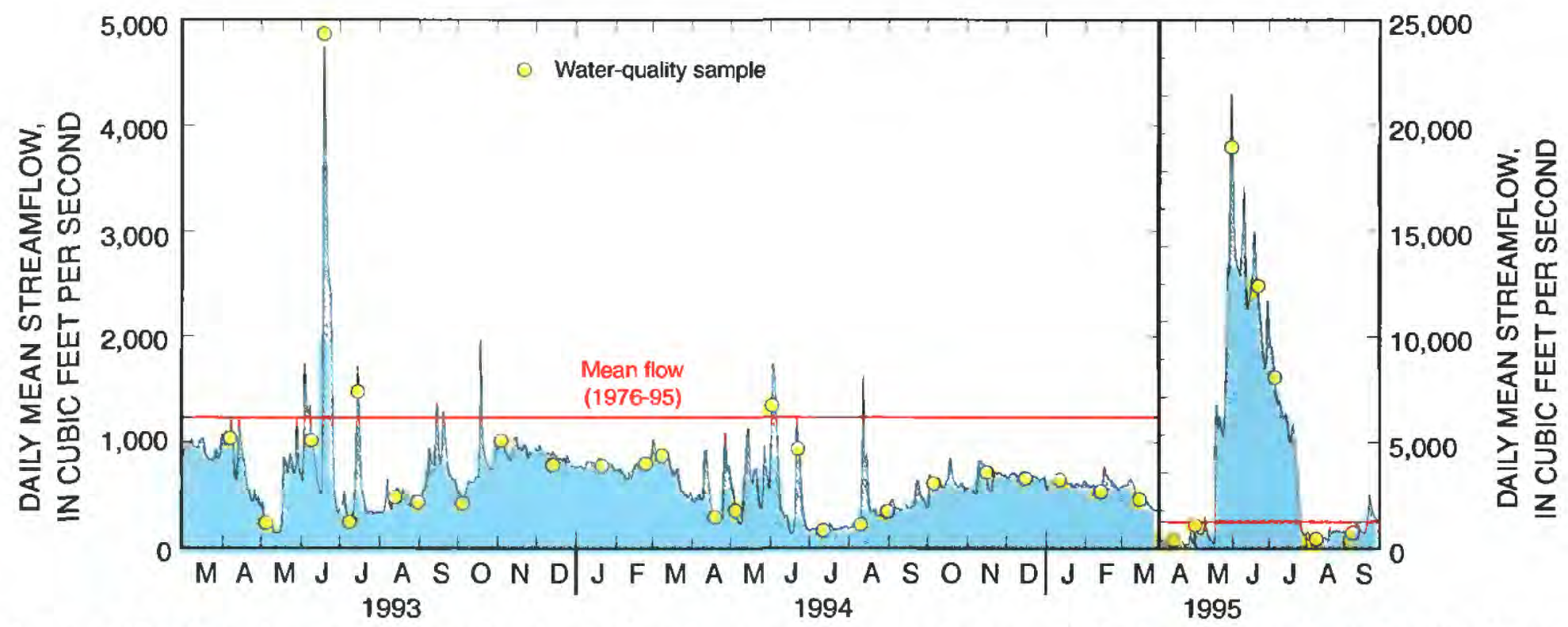

Figure 12. Map showing stream basin and land use (Fegeas and others, 1983) upstream from the fixed site, hydrograph showing streamflow at the fixed site during the study period, and photograph showing typical character of the stream at the fixed site: South Platte River near Kersey, Colorado. 


\section{South Platte River at Cooper Bridge, near Balzac, Colorado}

The fixed site at South Platte River at Cooper Bridge, near Balzac, Colorado, is located $74 \mathrm{mi}$ downstream from the site at South Platte River near Kersey, Colorado (fig. 13). The river flows eastward through agricultural land use in this segment. The first one-third of this segment composes the Narrows section of the river, where the alluvial valley is narrow (about $1 \mathrm{mi}$ wide) as it transects a rolling sand-hills topography formed from ancient dune fields. Downstream from the Narrows, the alluvial valley widens to more than $5 \mathrm{mi}$ in the vicinity of the Fort Morgan, Colorado, agricultural area. Several plains tributaries (Box Elder Creek, Crow Creek, Kiowa Creek, Bijou Creek, and Beaver Creek) flow into the South Platte River in this segment, but streamflow in these tributaries generally is smaller than $5 \mathrm{ft}^{3} / \mathrm{s}$.

The segment is underlain by Upper Cretaceous sedimentary rocks that primarily are sandstones, but also include the dark, organic-rich Pierre Shale, which subcrops under the river alluvium in the vicinity of Fort Morgan, Colorado. The alluvium is greater than $160 \mathrm{ft}$ thick through much of this segment, and the alluvial aquifer is from 5 to $10 \mathrm{mi}$ wide.

The channel of the South Platte River is mostly in a natural condition from Kersey to Balzac, Colorado. The stream gradient steepens somewhat downstream from Kersey to $7.83 \mathrm{ft} / \mathrm{mi}$ near Balzac (table 2). In this segment, the stream changes from meandering to braided; during low flows, the river generally is divided into four subchannels near Balzac. The predominant substrate near Balzac is sand, and bank stability (2.7) is fairly small. Much of the cottonwood and brush riparian zone in this segment is managed as Colorado State wildlife areas so that cultivated fields tend to be farther removed from the river compared to upstream segments.

\section{Land use in the entire $16,852-\mathrm{mi}^{2}$ South Platte} River Basin upstream from the fixed site near Balzac, Colorado, is 40.5 percent rangeland, 29.2 percent agricultural, 23.0 percent forest, and 7.3 percent other landuse categories (Fegeas and others, 1983). However, much of the water in the river from upstream sources is removed by irrigation ditches throughout the year, and the river is replenished by locally derived ground-water inflows. For example, during a water-quality study conducted along the river during April 1994, 1,485 $\mathrm{ft}^{3} / \mathrm{s}$ of water was removed from the river by irrigation ditches downstream from Kersey, Colorado, and the river was replenished by $1,430 \mathrm{ft}^{3} / \mathrm{s}$ from ground-water inflow (Litke, 1996). A large part of the water diversions occur in the Kersey to Balzac segment where five large ditches remove water to fill offstream irrigation water-storage reservoirs. The largest of these ditches (North Sterling Canal) is located just $0.7 \mathrm{mi}$ upstream from the site, and the ditch operations particularly affect the site. The ditches operate primarily from November through May, but when they are inactive during the irrigation season, numerous smaller irrigation ditches open to provide water to fields. Because water in the river near Balzac most often is predominated by local ground-water irrigation return flows, the site near Balzac is representative of agricultural land use.

The South Platte River in the vicinity of the fixed site is classified for recreational (noncontact) and agricultural use. In addition to the ditch withdrawals, a substantial quantity of water is pumped from the alluvial aquifer for supplemental irrigation water.

Mean streamflow at South Platte River at Cooper Bridge, near Balzac, Colorado, during the study period was $891 \mathrm{ft}^{3} / \mathrm{s}$ (table 2); annual mean streamflows were about one-half of the 20-year mean during water years 1993 and 1994 and more than twice the 20-year mean during water year 1995 (table 3). Annual mean flow near Balzac was less than near Kersey, Colorado (only about one-half of the Kersey flow during water year 1994), during the study period. The daily mean streamflow hydrograph for this site (fig. 13) shows that streamflow was quite variable throughout the year. Even seasonal flow patterns were not evident because flow was dependent on the effects of numerous upstream ditch operations. Streamflow during runoff in spring and summer of 1995 also was notable at this site; streamflow in excess of $10,000 \mathrm{ft}^{3} / \mathrm{s}$ was maintained for 25 days at this site.

Thirty-two water-quality samples were collected during the study period at South Platte River at Cooper Bridge, near Balzac, Colorado (fig. 13). The range in flow conditions was well represented; the minimum flow sampled was $13 \mathrm{ft}^{3} / \mathrm{s}$, and the maximum flow sampled was $14,700 \mathrm{ft}^{3} / \mathrm{s}$. The importance of local ground-water inflows represented in a sample, compared to water from upstream sources, can be estimated by subtracting total ditch diversions in the Kersey to Balzac, Colorado, segment from the flow near Kersey. This calculation indicated that ground-water inflow predominated for almost all samples, except those samples that were collected during runoff. 

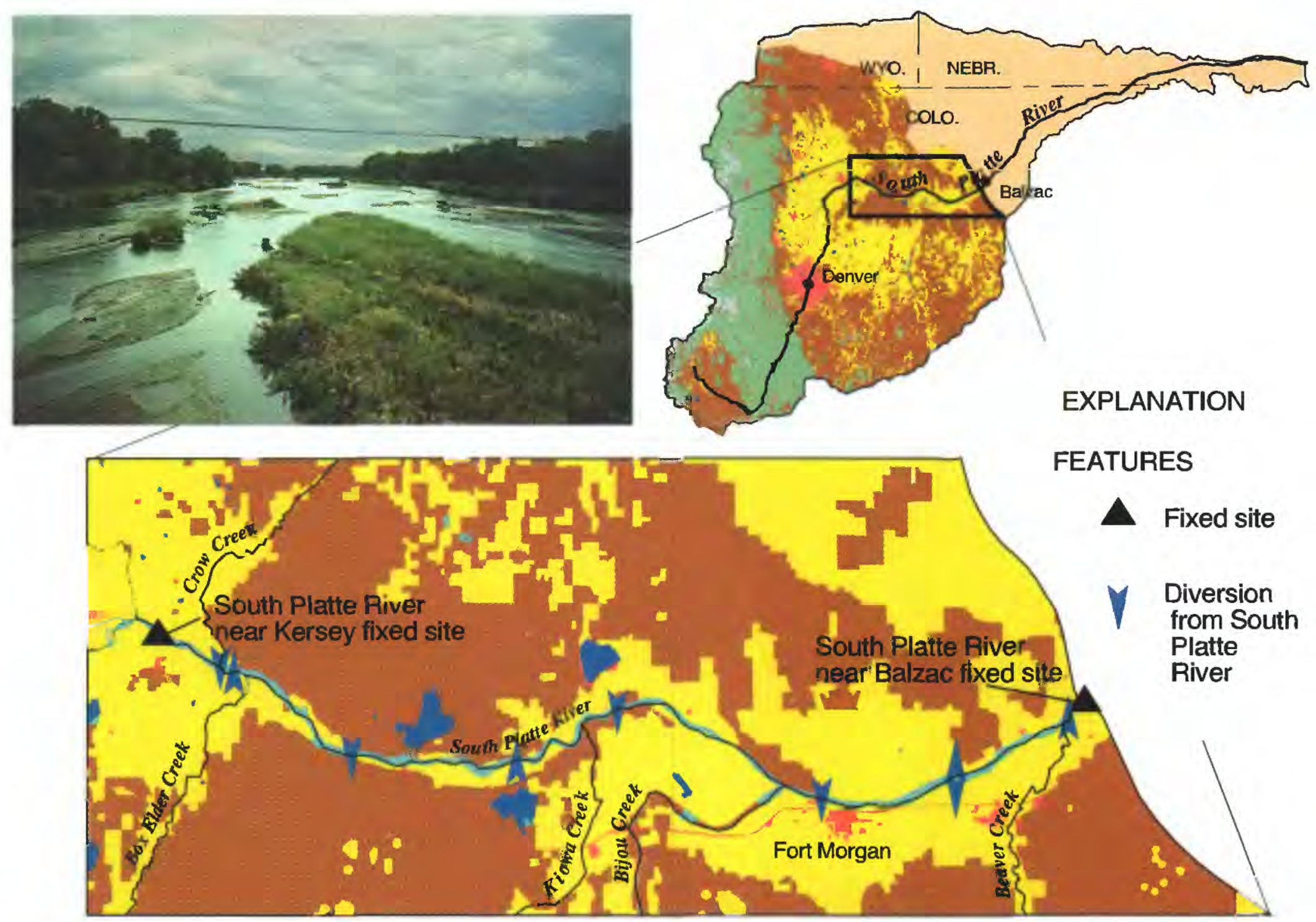

LAND USE AND PERCENT OF ENTIRE BASIN

\begin{tabular}{llllllll}
$\square$ & Urban (3.4) & $\square$ & Forest (23.0) & $\square$ & Barren land (0.8) & $0,3,6$ MILES \\
$\square$ & Agricultural (29.2) & $\square$ & Water (0.5) & $\square$ & Tundra (2.1) \\
\hline & Rangeland (40.5) & $\square$ & Wetlands (0.4) & $\square$ & Other $(0.1)$
\end{tabular}

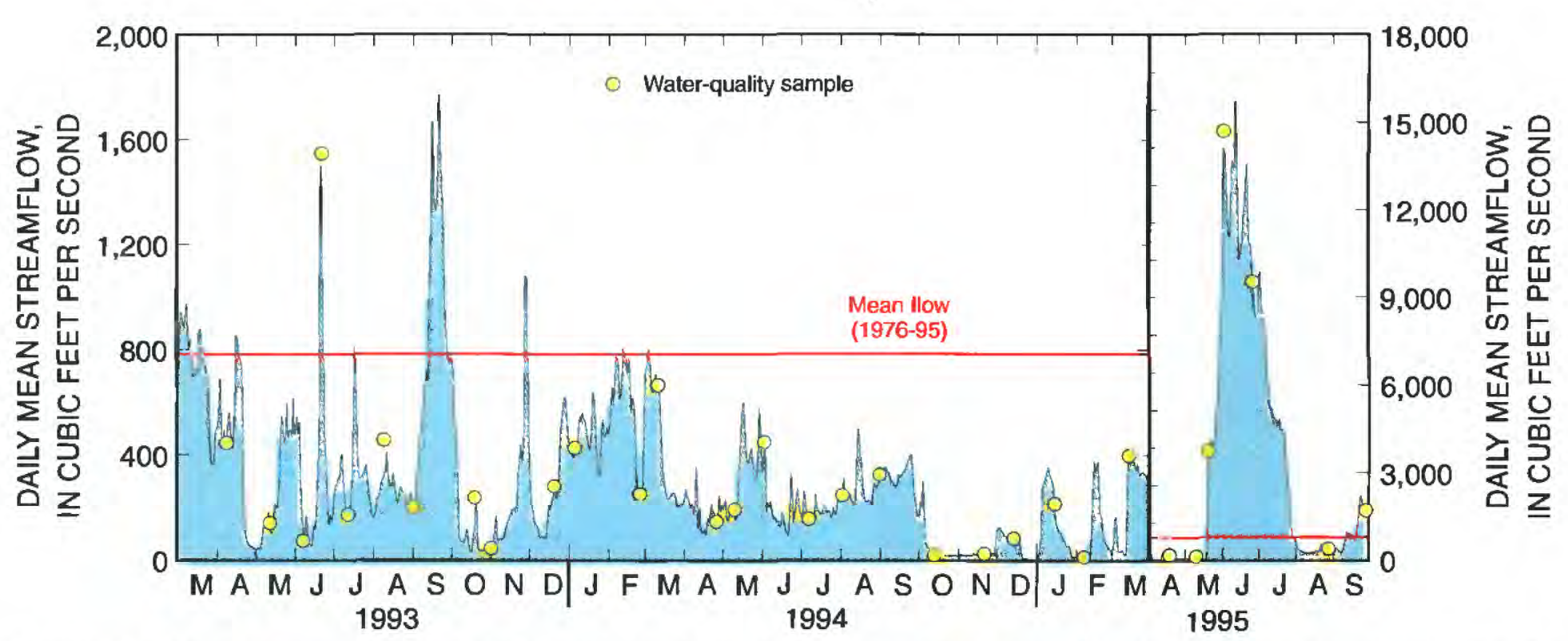

Figure 13. Map showing stream basin and land use (Fegeas and others, 1983) upstream from the fixed site, hydrograph showing streamflow at the fixed site during the study period, and photograph showing typical character of the stream at the fixed site: South Platte River at Cooper Bridge, near Balzac, Colorado. 


\section{South Platte River at North Platte, Nebraska}

The fixed site at South Platte River at North Platte, Nebraska, is located 178 mi downstream from the site at South Platte River at Cooper Bridge, near Balzac, Colorado (fig. 14). The river flows eastward through agricultural land use in this segment. Several plains tributaries (Cottonwood Creek, Lewis Creek, and Lodgepole Creek) flow into the South Platte River in this segment, but streamflow in these tributaries generally is smaller than $5 \mathrm{ft}^{3} / \mathrm{s}$, except during the irrigation season when the tributaries may convey irrigation return flows to the river.

The segment is underlain by Tertiary and Upper Cretaceous sedimentary rocks that primarily are sandstones, but also include conglomerate and unconsolidated sand and gravel of the Ogallala Formation. The alluvium is greater than $160 \mathrm{ft}$ thick through much of this segment, and the alluvial aquifer generally is less than 5 mi wide.

The channel of the South Platte River is mostly undisturbed from Balzac, Colorado, to North Platte, Nebraska, except where it has been channelized and reinforced with riprap where it passes by towns, especially in Nebraska. Stream gradient steepens somewhat downstream from Balzac to $8.04 \mathrm{ft} / \mathrm{mi}$ at North Platte (table 2). In this segment, the stream is braided. The predominant substrate at North Platte is sand, and bank stability (3.2) is somewhat larger than near Balzac. Because the alluvial valley is relatively narrow in the Nebraska part of the basin, cultivated fields tend to be located closer to the river than in upstream segments.

Land use in the entire $24,300-\mathrm{mi}^{2}$ South Platte River Basin upstream from the fixed site at North Platte, Nebraska, is 41.2 percent rangeland, 36.8 percent agricultural, 16.1 percent forest, and 5.9 percent other land use categories (Fegeas and others, 1983). However, much of the water in the river from upstream sources is removed by irrigation ditches. Eighteen ditches remove water from the river during the irrigation season, and the Korty Canal, located about 40 mi upstream from North Platte, Nebraska, removes almost all of the water from the river from October through April. Because water in the river at North Platte most often is predominated by ground-water irrigation return flows, the site at North Platte is representative of agricultural land use.

The South Platte River in the vicinity of the fixed site is classified for sustaining warm-water aquatic life and for agricultural use. Also, there is a minimum flow requirement in this segment because the South Platte River Compact requires that Colorado deliver at least $120 \mathrm{ft}^{3} / \mathrm{s}$ of water in the South Platte River at the State line from April 1 through October 15.

Mean streamflow at South Platte River at North Platte, Nebraska, during the study period was $719 \mathrm{ft}^{3} / \mathrm{s}$ (table 2); annual mean streamflows were about onehalf of the 20-year mean during water years 1993 and 1994, and more than twice the 20-year mean during water year 1995 (table 3 ). The daily mean streamflow hydrograph for this fixed site (fig. 14) shows that streamflow was fairly uniform throughout the year primarily because of the regulating effect of the Korty Canal diversion. Streamflow during runoff in spring and summer of 1995 was especially noteworthy at this site; streamflow rarely exceeds $500 \mathrm{ft}^{3} / \mathrm{s}$ at this site, yet, during the runoff of 1995 , a flow of $5,000 \mathrm{ft}^{3} / \mathrm{s}$ was exceeded for 38 consecutive days.

Thirty-two water-quality samples were collected during the study period at South Platte River at North Platte, Nebraska (fig. 14). The range in flow conditions was well represented; the minimum flow sampled was $144 \mathrm{ft}^{3} / \mathrm{s}$, and the maximum flow sampled was $11,900 \mathrm{ft}^{3} / \mathrm{s}$. The importance of local ground-water inflows to the river, compared to water from upstream sources, can be estimated by subtracting total ditch diversions in the Balzac, Colorado, to North Platte, Nebraska, segment from the flow near Balzac. This calculation indicated that groundwater inflow predominated almost all samples, except samples that were collected during runoff. 

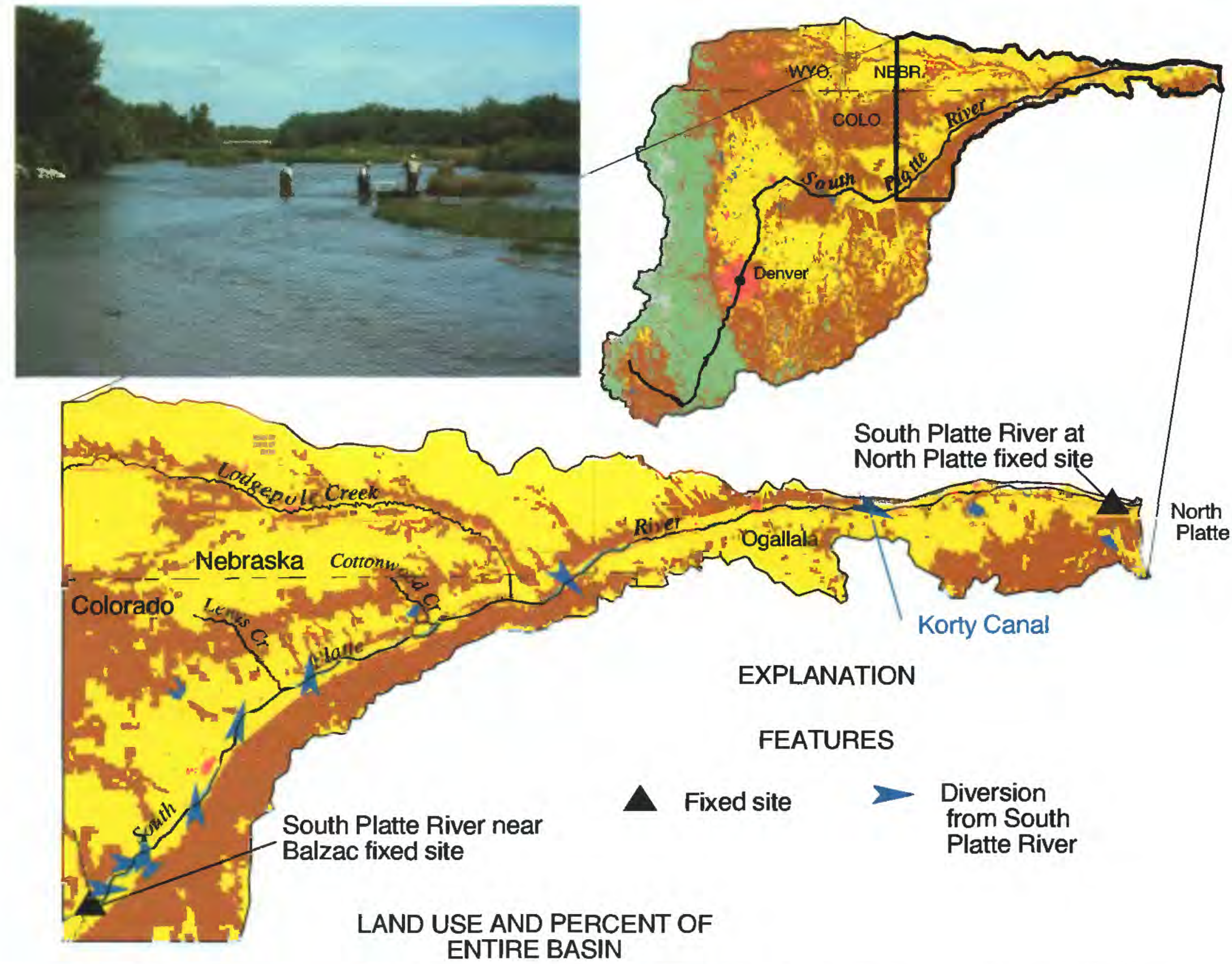

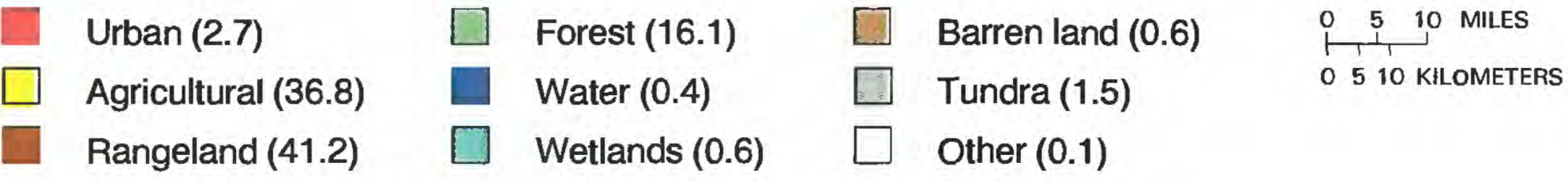

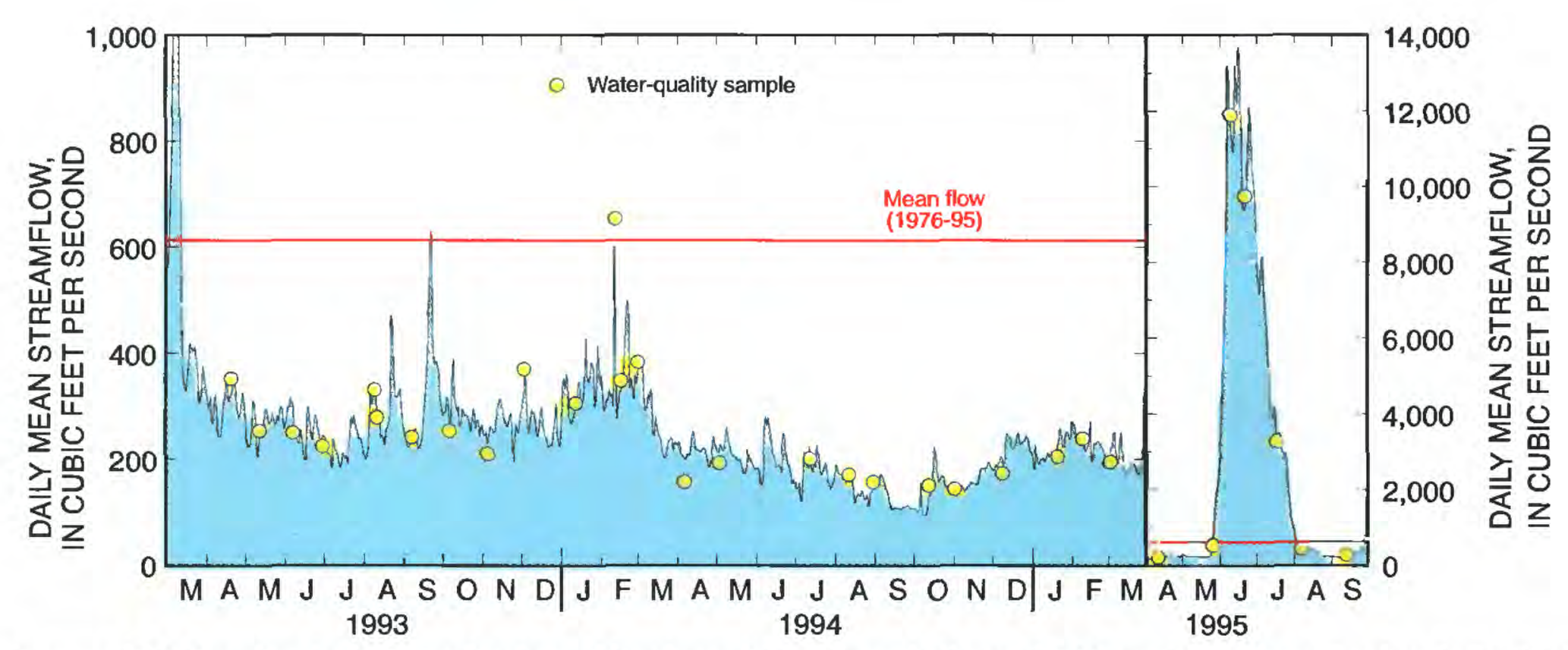

Figure 14. Map showing stream basin and land use (Fegeas and others, 1983) upstream from the fixed site, hydrograph showing streamflow at the fixed site during the study period, and photograph showing typical character of the stream at the fixed site: South Platte River at North Platte, Nebraska. 


\section{DATA COLLECTION}

Water-quality samples generally were collected at each fixed site at least monthly during March 1993 to September 1995. Additional samples were collected during snowmelt runoff and rainfall runoff and during specific water-quality studies. For example, Cherry Creek at Denver, Colorado; South Platte River at Denver, Colorado; and Lonetree Creek near Greeley, Colorado, were selected for more frequent sampling to test for the presence of pesticides in water from urban and agricultural land uses. Fewer samples were collected at Big Thompson River below Moraine Park near Estes Park, Colorado, where sampling did not begin until January 1995. The date of the last sample collected at each site varied from July 1995 to September 1995.

\section{Sampling Methods}

Field-collection and -processing equipment were made from Teflon, glass, or stainless steel to prevent sample contamination and to minimize analyte losses through adsorption. All sampling equipment was cleaned prior to use with a nonphosphate laboratory detergent and then rinsed with distilled water and finally by stream water just prior to sample collection. Depth-integrated water samples were collected across each stream by using the equal-width-increment method (Edwards and Glysson, 1988) and processed onsite using methods and equipment described by Shelton (1994). Samples for organic-carbon analysis were collected separately by dipping a baked glass bottle in the centroid of flow. During high flows, replicate suspended-sediment samples were collected using traditional suspended-sediment samplers (Guy and Norman, 1982). Samples to be analyzed for dissolved constituents were filtered onsite through $0.45-\mu \mathrm{m}$ capsule filters. Nutrient samples collected prior to October 1994 were preserved with mercuric chloride and immediately chilled to $4^{\circ} \mathrm{C}$; the use of mercuric chloride as a preservative was discontinued after October 1994. Water samples were sent to the USGS National Water Quality Laboratory in Arvada, Colorado, for analysis using standard USGS analytical methods (Fishman and Friedman, 1989; Patton and Truitt, 1992; Fishman, 1993). All analyses discussed in this report are for dissolved constituents unless otherwise specified. Suspended-sediment samples were sent to the USGS Sediment Analysis Laboratory in Vancouver, Washington, fer concentration and particle-size analysis.

Field measurements at the time of sampling included instantaneous streamflow, water temperature, dissolved-oxygen concentration, specific conductance, hydrogen-ion activity $(\mathrm{pH})$, and alkalinity (table 1). Streamflow-gaging stations are located at each fixed site for continuous measurement of streamflow. Hourly water-temperature data also were collected for at least 1 year at each site (except at Big Thompson River below Moraine Park, near Estes Park, Colorado).

Water-chemistry data summarized in this report are published in USGS annual data reports (Ugland, Cochran, and others, 1994; Ugland, Maura, and others, 1995; Crowfoot and others, 1996). These data and other types of data collected at the fixed sites (pesticides and trace metals in stream water; organic compounds and trace elements in streambed sediment and fish tissue; algal, benthic-invertebrate, and fish community data; and aquatic habitat data) also are available online via the World Wide Web (Qi and Dennehy, 1997: Uniform Resource Locator is http://webserver.cr.usgs.gov/nawqa/splt/splt_home.ht $\mathrm{ml})$.

\section{Quality Assurance}

As part of the fixed-site sampling, 14 percent of all samples obtained were for quality assurance and included 31 replicate samples and 33 blank samples. Replicate samples were prepared by splitting the environmental sample into duplicate samples. Blank samples were prepared in the field by processing deionized water through the sampling equipment in the same sequence as environmental samples. A summary of the quality-assurance data is listed in table 4.

For replicate samples, a relative percent difference (RPD) was calculated for each pair of data values by expressing, as a percentage, the difference between the two replicate values divided by the mean of the two replicate values. In table 4 , the 10 th percentile, 50th percentile (median), and 90 th percentile for RPDs are listed by constituent. These statistics indicate the range and distribution of errors for each constituent. The 10 th percentile of RPD was 0 percent for all constituents, and the median RPD was less than 
Table 4. Summary of quality-assurance data from fixed-site sampling

[mg/L, milligrams per liter; <, less than]

\begin{tabular}{|c|c|c|c|c|c|}
\hline \multirow[b]{2}{*}{ Constituent } & \multicolumn{3}{|c|}{$\begin{array}{c}\text { Replicates }^{\top} \\
\text { (relative percent difference) }\end{array}$} & \multicolumn{2}{|c|}{ Blanks $^{2}$} \\
\hline & $\begin{array}{c}\text { 10th } \\
\text { percentile }\end{array}$ & $\begin{array}{c}\text { 50th } \\
\text { percentile } \\
\text { (median) }\end{array}$ & $\begin{array}{c}\text { 90th } \\
\text { percentile }\end{array}$ & $\begin{array}{l}\text { Minimum } \\
\text { reporting limit } \\
(\mathrm{mg} / \mathrm{L})\end{array}$ & $\begin{array}{c}\text { Median } \\
\text { concentration } \\
(\mathrm{mg} / \mathrm{L})\end{array}$ \\
\hline \multicolumn{6}{|l|}{ Major constituents: } \\
\hline Dissolved solids & 0 & 0.6 & 5.4 & 1.0 & 3.9 \\
\hline \multicolumn{6}{|l|}{ Major ions and metals: } \\
\hline Calcium & 0 & 0 & 4.4 & 0.02 & 0.13 \\
\hline Chloride & 0 & 1.4 & 3.8 & 0.1 & $<0.1$ \\
\hline Fluoride & 0 & 0 & 11 & 0.1 & $<0.1$ \\
\hline Iron & 0 & 11 & 67 & 0.003 & 0.006 \\
\hline Magnesium & 0 & 0 & 5.7 & 0.01 & 0.01 \\
\hline Manganese & 0 & 0 & 15 & 0.001 & $<0.001$ \\
\hline Potassium & 0 & 2.4 & 16 & 0.1 & $<0.1$ \\
\hline Silica & 0 & 0 & 6.4 & 0.01 & 0.69 \\
\hline Sodium & 0 & 0 & 8.0 & 0.2 & 0.4 \\
\hline Sulfate & 0 & 0 & 5.1 & 0.1 & 0.1 \\
\hline
\end{tabular}

Nutrients:

Nitrogen:

Total organic nitrogen

plus ammonia

Dissolved organic nitrogen

plus ammonia

Ammonia

$0 \quad 5.1$

67

0.2

$<0.2$

0

29

0.2

$<0.2$

Nitrite

0

0

67

0.01

0.01

Nitrite plus nitrate

0

8.7

0.01

$<0.01$

0

1.3

10

0.01

0.03

Phosphorus

Total

0

2.2

87

0.01

0.01

Total dissolved

4.3

29

0.01

$<0.01$

Orthophosphate

0

1.5

9.5

0.01

$<0.01$

Organic carbon:

Suspended

0

24

0.1

0.1

Dissolved

0

2.2

6.7

0.1

0.2

${ }^{1}$ Number of replicate pairs was 31 .

${ }^{2}$ Number of blanks was 33 .

5 percent for 19 of 21 constituents, which indicated that the reproducibility of analytical results was quite good for most constituents. Two constituents, iron and total organic nitrogen plus ammonia, had a median RPD greater than 5 percent, which indicated that, for these two constituents, comparisons between similar values need to be interpreted carefully. Some constituents had an occasional large value (90th percentile) for RPD, which was not a concern because the large RPD was caused by samples with small concentrations near the minimum reporting limit; for example, replicate results for ammonia of 0.02 and $0.04 \mathrm{mg} / \mathrm{L}$ produced a 90th percentile for RPD of 67 percent (table 4).

Fourteen of the 21 constituents had median blank concentrations at or less than the minimum reporting limit for that constituent, which indicated no recurring contamination or bias for those constituents. A few major constituents (calcium, iron, silica, and 
sodium), dissolved solids, and nitrite plus nitrate had recurring small concentrations in blanks. The lowlevel detections in blanks generally did not affect interpretation of the data because the concentrations in the environmental samples were at least an order of magnitude greater than in the blanks; however, care needs to be taken in evaluating data from the few environmental samples where low-level concentrations were present, most notably in samples from pristine mountain fixed sites.

\section{DESCRIPTION OF WATER QUALITY DURING 1993-95}

The water quality of a stream can be discussed in terms of constituent concentrations and in terms of constituent loads. Concentrations are important because they define the state of the stream at a point in time and because excessive concentrations of certain constituents can impair the health of aquatic organisms. Concentrations also are important to water users who withdraw water from streams for public supply, industrial, agricultural, or other uses; excessive concentrations of certain constituents can render the water unusable for these purposes. Constituent loads, which are the product of concentration and streamflow, are important because the quantity of material in a stream generally needs to be managed to improve the concentrations in a stream. In this section, concentrations and then loads are discussed. Constituents are discussed in the order of major groups presented in table 1.

\section{Concentrations}

In this section, water-column measurements at fixed sites are compared using boxplots and multiplecomparison tests. Data distributions are displayed graphically by using truncated boxplots (Helsel and Hirsch, 1992, p. 26). These plots show five percentiles of the data distribution: 10th, 25th, 50th (median), 75 th, and 90th. Individually, boxplots can indicate the properties of the distribution, such as spread and skewness. Side-by-side boxplots are presented in this report (for example, fig. 15) so that data from the fixed sites can be visually compared. Similar boxplots indicate that data values are comparable for those fixed sites. A number placed above a boxplot indicates the sample size (number of observations represented by the boxplot).

Similarity between data at fixed sites can be more precisely evaluated by use of statistical comparison tests. For this analysis, the Kruskal-Wallis test (Iman and Conover, 1983) was used to test for differences in median values. This test was calculated by performing a one-way analysis of variance on the ranks of the data (Conover and Iman, 1981). At a confidence level of 0.05 , significant differences were found among the fixed sites for all of the watercolumn measurements listed in table 1. Differences between individual sites were next evaluated by applying Tukey's multiple comparison test (Helsel and Hirsch, 1992) to the rank-transformed data. The results of the multiple comparison tests are displayed by placement of letters above the boxplots for each fixed site to indicate significant groupings in median values. The letter ' $A$ ' is used to represent the site with the largest median concentration, and successive letters represent sites with correspondingly smaller median concentrations. For example, if a single boxplot is designated with the letter ' $A$,' then that fixed site has a significantly larger median concentration than the other fixed sites; if boxplots for two fixed sites share the letter ' $A$,' then those two sites have a larger median concentration than the other sites, but are not distinguishable from each other. In some cases, the groupings overlap, and then a site is represented by more than one letter. For example if three sites are labeled 'A,' 'AB,' and ' $B$,' respectively, then the first and third sites are significantly different, but the second site is not different from either the first or the third site.

Selected State chronic stream standards are listed in table 5 for use as a point of reference for water quality; chronic standards are levels relevant to long-term exposure, which are defined as levels not to be exceeded by a single representative sample or the average of all samples collected during a 30-day period. Stream standards vary based on the use classification for each stream segment and may include aquatic-life standards, drinking-water standards, and agricultural-use standards. The standards are documented in publications by State environmental agencies (Colorado Department of Health, 1993a, b; Nebraska Department of Environmental Quality, 1996). Single concentrations in excess of a chronic numeric standard do not constitute noncompliance with the standard because it is recognized that a 

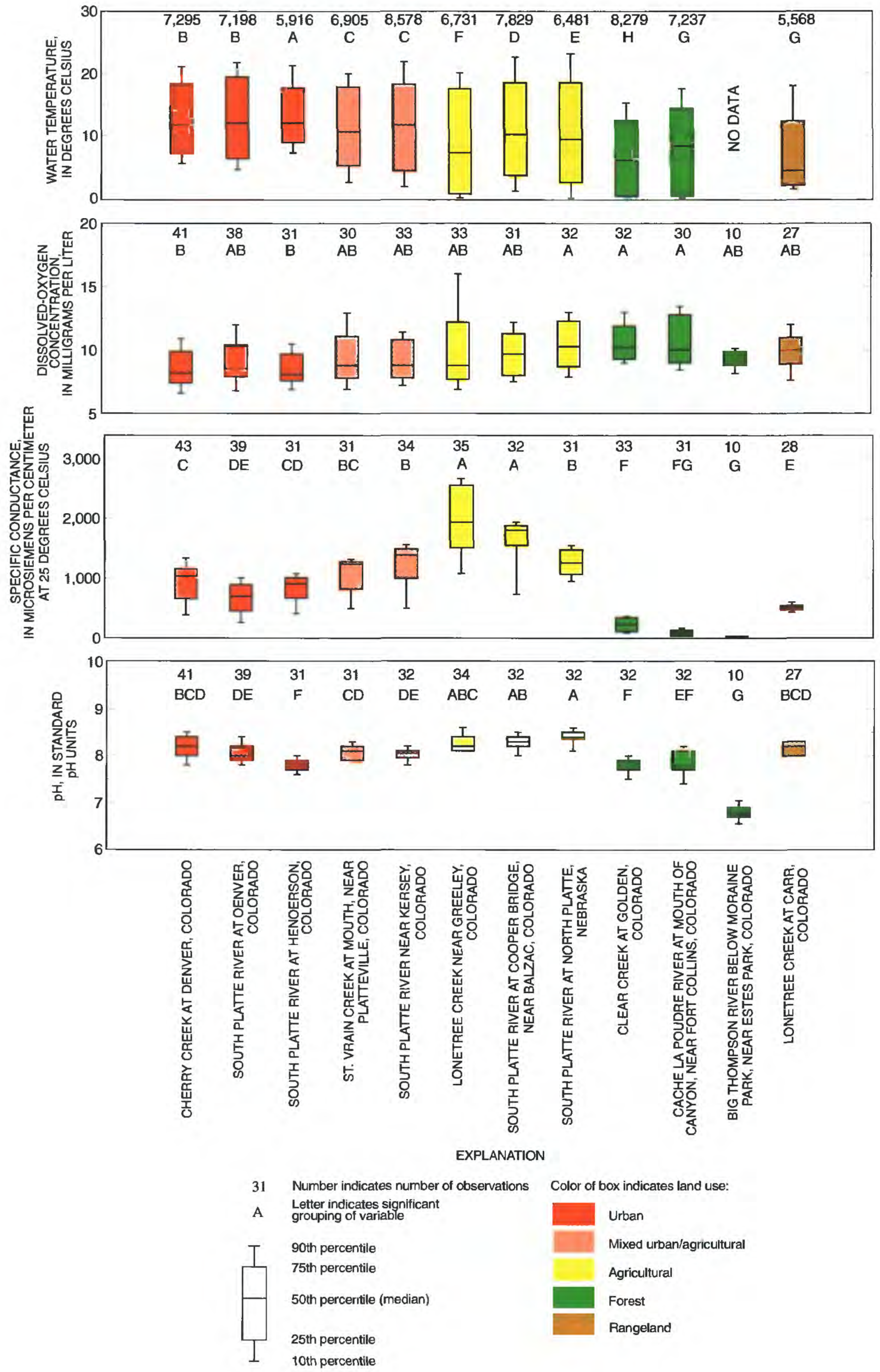

Figure 15. Distributions of water temperature, dissolved-oxygen concentration, specific conductance, and $\mathrm{pH}$ at the fixed sites. 
Table 5. Selected chronic stream-segment standards for the fixed sites

[ring/L, milligrams per liter; $\mu \mathrm{g} / \mathrm{L}$, micrograms per liter; DO, dissolved oxygen; NH3, ammonia; NO2, nitrite; NO3, nitrate; Cl, chloride; SO4, sulfate; Fe, iron; Mn, manganese; sp, spawning; SC, specific conductance; --, no applicable standard; data from Colorado Department of Health (1993a, b); Nebraska Department of Environmental Quality (1996)]

\begin{tabular}{|c|c|c|c|c|}
\hline \multirow{2}{*}{ Site name } & \multirow{2}{*}{$\begin{array}{c}\text { Segment } \\
\text { classification }^{1}\end{array}$} & \multicolumn{3}{|c|}{ Numeric standards } \\
\hline & & Physical & $\begin{array}{l}\text { Inorganic } \\
(\mathrm{mg} / \mathrm{L})\end{array}$ & $\begin{array}{l}\text { Metals } \\
(\mu \mathrm{g} / \mathrm{L})\end{array}$ \\
\hline Cherry Creek at Denver, Colorado & $\begin{array}{l}\text { Recreation } 2 \\
\text { Water supply } \\
\text { Agriculture }\end{array}$ & $\begin{array}{l}\mathrm{DO}=5.0 \mathrm{mg} / \mathrm{L} \\
\mathrm{pH}=6.5-9.0\end{array}$ & $\begin{aligned} \mathrm{NH} 3 & =0.10 \\
\mathrm{NO} 2 & =0.5 \\
\mathrm{NO} 3 & =10 \\
\mathrm{Cl} & =250 \\
\mathrm{SO} 4 & =250\end{aligned}$ & $\begin{aligned} \mathrm{Fe} & =300 \\
\mathrm{Mn} & =50\end{aligned}$ \\
\hline South Platte River at Denver, Colorado & $\begin{array}{l}\text { Aquatic life, warm } 1 \\
\text { Recreation } 2 \\
\text { Water supply } \\
\text { Agriculture }\end{array}$ & $\begin{aligned} \mathrm{DO} & =5.0 \mathrm{mg} / \mathrm{L} \\
\mathrm{pH} & =6.5-9.0\end{aligned}$ & $\begin{aligned} \mathrm{NH} 3 & =0.06 \\
\mathrm{NO} 2 & =0.5 \\
\mathrm{NO} 3 & =10 \\
\mathrm{Cl} & =250 \\
\mathrm{SO} 4 & =250\end{aligned}$ & $\begin{aligned} \mathrm{Fe} & =300 \\
\mathrm{Mn} & =50\end{aligned}$ \\
\hline Clear Creek at Golden, Colorado & $\begin{array}{l}\text { Aquatic life, cold } 1 \\
\text { Recreation } 1 \\
\text { Water supply } \\
\text { Agriculture }\end{array}$ & $\begin{aligned} \mathrm{DO} & =6.0 \mathrm{mg} / \mathrm{L} \\
\mathrm{DO}(\mathrm{sp}) & =7.0 \mathrm{mg} / \mathrm{L} \\
\mathrm{pH} & =6.5-9.0\end{aligned}$ & $\begin{aligned} \mathrm{NH} 3 & =0.02 \\
\mathrm{NO} 2 & =0.05 \\
\mathrm{NO} 3 & =10 \\
\mathrm{Cl} & =250 \\
\mathrm{SO} 4 & =250\end{aligned}$ & $\begin{array}{l}\mathrm{Fe}=300 \\
\mathrm{Mn}=50\end{array}$ \\
\hline $\begin{array}{l}\text { South Platte River at Henderson, } \\
\text { Colorado }\end{array}$ & $\begin{array}{l}\text { Recreation } 2 \\
\text { Water supply } \\
\text { Agriculture }\end{array}$ & $\begin{array}{l}\mathrm{pH}=6.5-9.0 \\
\mathrm{DO}=4.5-5.0 \mathrm{mg} / \mathrm{L}\end{array}$ & $\begin{aligned} \mathrm{NH} 3 & =0.10 \\
\mathrm{NO} 2 & =1.0 \\
\mathrm{NO} 3 & =10 \\
\mathrm{Cl} & =250 \\
\mathrm{SO} 4 & =250\end{aligned}$ & $\begin{array}{r}\mathrm{Fe}=300 \\
\mathrm{Mn}=400\end{array}$ \\
\hline $\begin{array}{l}\text { St. Vrain Creek at mouth, near } \\
\text { Platteville, Colorado }\end{array}$ & $\begin{array}{l}\text { Aquatic life, warm } 1 \\
\text { Recreation } 2 \\
\text { Agriculture }\end{array}$ & $\begin{array}{l}\mathrm{DO}=5.0 \mathrm{mg} / \mathrm{L} \\
\mathrm{pH}=6.5-9.0\end{array}$ & $\begin{array}{l}\mathrm{NH} 3=0.06 \\
\mathrm{NO} 2=0.5\end{array}$ & $\begin{aligned} \mathrm{Fe} & =300 \\
\mathrm{Mn} & =50\end{aligned}$ \\
\hline $\begin{array}{l}\text { Big Thompson River below Moraine } \\
\text { Park, near Estes Park, Colorado }\end{array}$ & $\begin{array}{l}\text { Aquatic life, cold } 1 \\
\text { Recreation } 2 \\
\text { Water supply } \\
\text { Agriculture }\end{array}$ & $\begin{aligned} \mathrm{DO} & =6.0 \mathrm{mg} / \mathrm{L} \\
\mathrm{DO}(\mathrm{sp}) & =7.0 \mathrm{mg} / \mathrm{L} \\
\mathrm{pH} & =6.5-9.0\end{aligned}$ & $\begin{aligned} \mathrm{NH} 3 & =0.02 \\
\mathrm{NO} 2 & =0.05 \\
\mathrm{NO} 3 & =10 \\
\mathrm{Cl} & =250 \\
\mathrm{SO} 4 & =250\end{aligned}$ & $\begin{aligned} \mathrm{Fe} & =300 \\
\mathrm{Mn} & =50\end{aligned}$ \\
\hline $\begin{array}{l}\text { Cache la Poudre River at mouth of } \\
\text { canyon, near Fort Collins, Colorado }\end{array}$ & $\begin{array}{l}\text { Recreation } 2 \\
\text { Water supply } \\
\text { Agriculture }\end{array}$ & $\begin{aligned} \mathrm{DO} & =5.0 \mathrm{mg} / \mathrm{L} \\
\mathrm{DO}(\mathrm{sp}) & =7.0 \mathrm{mg} / \mathrm{L} \\
\mathrm{pH} & =6.5-9.0\end{aligned}$ & $\begin{aligned} \mathrm{NH} 3 & =0.02 \\
\mathrm{NO} 2 & =0.05 \\
\mathrm{NO} 3 & =10 \\
\mathrm{Cl} & =250 \\
\mathrm{SO} 4 & =250\end{aligned}$ & $\begin{aligned} \mathrm{Fe} & =300 \\
\mathrm{Mn} & =50\end{aligned}$ \\
\hline Lonetree Creek at Carr, Colorado & $\begin{array}{l}\text { Recreation } 2 \\
\text { Agriculture }\end{array}$ & $\begin{array}{l}\mathrm{DO}=5.0 \mathrm{mg} / \mathrm{L} \\
\mathrm{pH}=6.5-9.0\end{array}$ & - & -- \\
\hline Lonetree Creek near Greeley, Colorado & $\begin{array}{l}\text { Recreation } 2 \\
\text { Agriculture }\end{array}$ & $\begin{array}{l}\mathrm{DO}=5.0 \mathrm{mg} / \mathrm{L} \\
\mathrm{pH}=6.5-9.0\end{array}$ & - & -- \\
\hline
\end{tabular}


[mg/L, milligrams per liter; $\mu \mathrm{g} / \mathrm{L}$, micrograms per liter; DO, dissolved oxygen; NH3, ammonia; NO2, nitrite; NO3, nitrate; Cl, chloride; SO4, sulfate; Fe, iron; Mn, manganese; sp, spawning; SC, specific conductance; --, no applicable standard; data from Colorado Department of Health (1993a, b); Nebraska Department of Environmental Quality (1996)]

\begin{tabular}{|c|c|c|c|c|}
\hline \multirow[b]{2}{*}{ Site name } & \multirow{2}{*}{$\begin{array}{c}\text { Segment } \\
\text { classification }\end{array}$} & \multicolumn{3}{|c|}{ Numeric standards } \\
\hline & & Physical & $\begin{array}{c}\text { Inorganic } \\
(\mathrm{mg} / \mathrm{L})\end{array}$ & $\begin{array}{l}\text { Metals } \\
(\mu \mathrm{g} / \mathrm{L})\end{array}$ \\
\hline $\begin{array}{l}\text { South Platte River near Kersey, } \\
\text { Colorado }\end{array}$ & $\begin{array}{l}\text { Recreation } 2 \\
\text { Agriculture }\end{array}$ & $\begin{array}{l}\mathrm{DO}=5.0 \mathrm{mg} / \mathrm{L} \\
\mathrm{pH}=6.5-9.0\end{array}$ & $\begin{array}{l}\mathrm{NH} 3=0.10 \\
\mathrm{NO} 2=0.5\end{array}$ & - \\
\hline $\begin{array}{l}\text { South Platte River at Cooper Bridge, } \\
\text { near Balzac, Colorado }\end{array}$ & $\begin{array}{l}\text { Recreation } 2 \\
\text { Agriculture }\end{array}$ & $\begin{array}{l}\mathrm{DO}=5.0 \mathrm{mg} / \mathrm{L} \\
\mathrm{pH}=6.5-9.0\end{array}$ & $\begin{array}{l}\mathrm{NH} 3=0.10 \\
\mathrm{NO} 2=0.5\end{array}$ & - \\
\hline $\begin{array}{l}\text { South Platte River at North Platte, } \\
\text { Nebraska }\end{array}$ & $\begin{array}{l}\text { Aquatic life, warm } 1 \\
\text { Agriculture }\end{array}$ & $\begin{array}{l}\mathrm{DO}=3.0-5.0 \mathrm{mg} / \mathrm{L} \\
\mathrm{pH}=6.5-9.0 \\
\mathrm{SC}=3,000\end{array}$ & $\begin{array}{l}\mathrm{NH} 3=\text { varies }^{2} \\
\mathrm{NO} 3=100\end{array}$ & - \\
\hline
\end{tabular}

\section{${ }^{1}$ Segment classifications for Colorado are defined as follows (Nebraska classifications are similar):}

Recreation 1-These surface waters are suitable or intended to become suitable for recreational activities in or on the water when the ingestion of small quantities of water is likely to occur. Such waters include, but are not limited to, those used for swimming, rafting, kayaking and waterskiing.

Recreation 2-These surface waters are suitable or intended to become suitable for recreational uses on or about the water which are not included in the primary contact subcategory, including, but not limited to, fishing and other streamside or lakeside recreation.

Agriculture-These surface waters are suitable or intended to become suitable for irrigation of crops usually grown in Colorado and which are not hazardous as drinking water for livestock.

Aquatic life-These surface waters presently support aquatic life uses as described below, or such uses may reasonably be expected in the future due to the suitability of present conditions, or the waters are intended to become suitable for such uses as a goal:

Cold Water 1-These are waters that (1) currently are capable of sustaining a wide variety of cold water biota. including sensitive species, or (2) could sustain such biota but for correctable water- quality conditions.

Warm Water 1 - These are waters that (1) currently are capable of sustaining a wide variety of warm water biota, including sensitive species, or (2) could sustain such biota but for correctable water-quality conditions.

Water supply-These surface waters are suitable or intended to become suitable for potable water supplies. After receiving standard treatment, these waters will meet drinking-water regulations.

${ }^{2}$ Standard varies depending on $\mathrm{pH}$ and water temperature. 
numeric standard may be exceeded due to temporary natural conditions, such as unusually high precipitation. A rule of thumb is that the numeric standard should not be exceeded by 85 percent of the data (Colorado Department of Health, 1993b). When occasional sampling indicates a potential water-quality problem, more frequent sampling may be needed to document whether a single exceedance is representative of acute (1-day average) or chronic (30-day average) conditions.

\section{Field Measurements}

Field measurements include water temperature, dissolved-oxygen concentration, specific conductance, $\mathrm{pH}$, and alkalinity. These measurements can be made onsite and provide a general picture of water quality at the fixed sites. Boxplots of water temperature, dissolved-oxygen concentration, specific conductance, and $\mathrm{pH}$ are shown in figure 15; alkalinity is discussed in the section on major ions.

Water temperature is an important stream characteristic for several reasons. Water temperature affects the metabolism of aquatic organisms and their ability to survive and reproduce, and changes in water temperature can alter the structure of the aquatic community. Water temperature also affects the reaction rates of instream processes; for example, increased temperatures accelerate the biodegradation of organic material that, in turn, decreases dissolvedoxygen concentrations in water. Water at elevated temperatures may be unsuitable for some recreational uses and for some industrial uses, such as water for cooling. Water temperatures in streams are affected by solar radiation, air temperature, ground temperature, precipitation, and surface-water and ground-water inflows.

Water-temperature data shown in figure 15 are hourly temperature data obtained from temperature monitors during water year 1994 and include several thousand observations at each fixed site, depending on the amount of data lost due to instrument malfunction. Median water temperatures at the sites during water year 1994 ranged from $4.4^{\circ} \mathrm{C}$ at Lonetree Creek at Carr, Colorado, to $12.0^{\circ} \mathrm{C}$ at South Platte at Denver, Colorado, and South Platte River at Henderson, Colorado. Statistical tests indicated significant differences in water temperature between most sites even though the boxplots appeared similar; the power of the statis- tical tests to detect differences is large for water temperature due to the large number of observations at each site.

Median water temperatures were highest at urban fixed sites. Heat is produced in urban areas by the combustion of fuels to run vehicles and to heat buildings, and dark urban materials (concrete and macadam) also absorb heat from the sun. Among the three urban sites, median water temperature was highest at South Platte River at Henderson, Colorado; water at this site primarily is derived from warm wastewater-treatment-plant effluent. Variability in water temperature (indicated by the length of the boxplot in fig. 15) was smallest at Henderson due to the single predominant source of water. Water temperatures were next highest at sites having mixed urban/agricultural land use followed by sites having agricultural land use. Warm temperatures in agricultural areas probably were due to the lack of shade from trees and because of heat absorbed from the sun by dark-colored soils in tilled fields. Variability in water temperatures was largest at agricultural sites, probably due to the extreme ranges in air temperature on the plains. Water temperatures were lowest at sites in forest and rangeland. Forested areas are cool because of shade from trees and the high elevations of the land. Water temperatures were cool at the rangeland site because the water primarily was derived from ground water; variability in water temperature was small at this site.

Water temperatures have a daily cycle and a seasonal cycle. Daily and seasonal variability are shown for a warm urban fixed site (South Platte River at Denver, Colorado) and a cool forest site (Clear Creek at Golden, Colorado) in figure 16. Temperatures at the forest site were lower throughout the year than temperatures at the urban site. However, the daily and seasonal patterns were similar at the two sites, except during winter when temperatures at the forest site were almost $0^{\circ} \mathrm{C}$ and fluctuated little. The seasonal range in temperatures at both sites was about $18^{\circ} \mathrm{C}$, whereas the average daily range in temperatures was about $3^{\circ} \mathrm{C}$. The three sites on the lower South Platte River (near Kersey, near Balzac, and at North Platte) had the largest seasonal ranges in temperature (average of $24.5^{\circ} \mathrm{C}$ ) and average daily ranges in temperature (average of $5.2^{\circ} \mathrm{C}$ ). Daily ranges in temperature occasionally were greater than $10^{\circ} \mathrm{C}$, and these large daily ranges in temperatures generally 


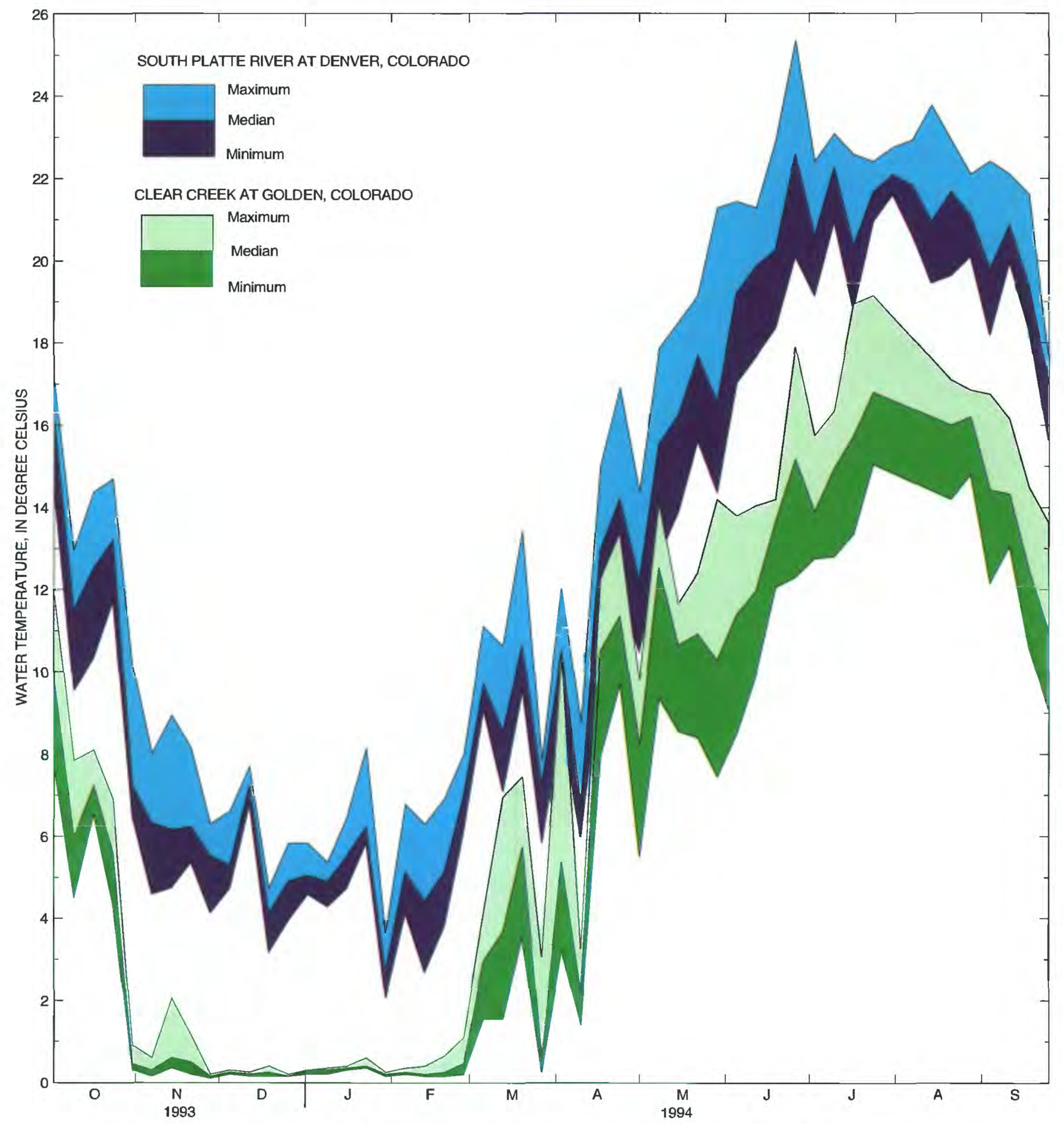

Figure 16. Daily maximum, median, and minimum water temperatures during water year 1994 at South Platte River at Denver, Colorado, and Clear Creek at Golden, Colorado [data are for Sunday of each week]. 
occurred on spring or summer days when stream depths were shallow.

Among the fixed sites, three (South Platte River at Denver, Colorado; St. Vrain Creek at mouth, near Platteville, Colorado; and South Platte River at North Platte, Nebraska) are classified as suitable for warmwater aquatic life (water temperature less than $30^{\circ} \mathrm{C}$ ), and two sites (Clear Creek at Golden, Colorado, and Big Thompson River below Moraine Park, near Estes Park, Colorado) are classified as suitable for coldwater aquatic life (temperature less than $20^{\circ} \mathrm{C}$ ) (table 5). At sites classified suitable for aquatic life, water temperatures need to maintain a normal pattern of diurnal and seasonal fluctuation with no abrupt changes. During water year 1994, water temperature at the warm-water sites did not exceed $30^{\circ} \mathrm{C}$. Water temperature at Clear Creek (cold-water site) exceeded $20^{\circ} \mathrm{C}$ during 5 days, with a maximum of $20.4^{\circ} \mathrm{C}$.

Dissolved-oxygen concentrations in water are important because oxygen is needed for respiration by many aquatic organisms and because oxygen in water is needed for biologically mediated aerobic decomposition of organic matter. The amount of oxygen that can be dissolved in water is inversely related to water temperature and directly related to atmospheric pressure. Oxygen is depleted in water through respiratory uptake by organisms and by processes that consume organic matter in streams. Oxygen is replenished in streams by diffusion from the atmosphere, and this process is accelerated where streamflow is agitated. Oxygen also is replenished in streams as a byproduct of photosynthesis by aquatic plants.

Median dissolved-oxygen concentrations at the fixed sites (fig. 15) ranged from $8.1 \mathrm{mg} / \mathrm{L}$ at South Platte River at Henderson, Colorado, to $10.3 \mathrm{mg} / \mathrm{L}$ at South Platte River at North Platte, Nebraska. Because dissolved-oxygen concentrations are related to water temperatures, those sites that had colder water temperatures tended to have larger dissolved-oxygen concentrations. The warm urban sites had significantly smaller dissolved-oxygen concentrations than the cold forest sites. Dissolved-oxygen concentrations varied the most at agricultural sites where water temperature also varied the most.

Stream standards at the fixed sites set a minimum value for dissolved-oxygen concentration from 3.0 to $7.0 \mathrm{mg} / \mathrm{L}$ (table 5). None of the dissolvedoxygen concentrations at the sites were smaller than these standards. However, dissolved-oxygen concentrations have a diurnal cycle with concentrations smallest during the night when aquatic photosynthesis is not active. Water samples collected for this study were collected during daylight hours; sampling times were comparable among the fixed sites so that data can be compared between the sites, but the data did not represent night-time conditions at the sites.

Specific conductance is a measure of the ability of a substance to conduct an electrical current. In water, specific conductance increases in proportion to the quantity of mineral salts dissolved in the water. Specific conductance, therefore, is an indication of the concentration of dissolved solids (salinity) in streams; for the fixed sites, the conversion factor between specific conductance and dissolved solids varied from 0.53 to 0.88 and averaged about 0.7 , so a sample that had a specific conductance of $1,000 \mu \mathrm{S} / \mathrm{cm}$ would have a dissolved-solids concentration of about $700 \mathrm{mg} / \mathrm{L}$. There are no State standards for specific conductance for streams in the study area.

Median specific conductance varied substantially at the fixed sites (fig. 15) ranging from $29 \mu \mathrm{S} / \mathrm{cm}$ at Big Thompson River below Moraine Park, near Estes Park, Colorado, to $1,940 \mu \mathrm{S} / \mathrm{cm}$ at Lonetree Creek near Greeley, Colorado. Median specific conductance was significantly largest at two sites representing agricultural land use and smallest at the three sites representing forest land use. Median specific conductance increased in the South Platte River in a downstream direction from Denver to Henderson to Kersey to Balzac, Colorado, and then decreased between Balzac and North Platte, Nebraska.

Hydrogen-ion activity in water is a measure of the acidic or basic character of the water and is expressed in terms of $\mathrm{pH}$ (the negative base- $10 \log$ of hydrogen-ion activity); a $\mathrm{pH}$ larger than 7 indicates more basic water and a $\mathrm{pH}$ less than 7 indicates more acidic water. Acidic water causes corrosion of metal pipes. A pH outside the range of 6.5 to 9.0 can be harmful to fish and aquatic macroinvertebrates. Water having a $\mathrm{pH}$ outside this range also can result in increased concentrations of potentially toxic substances, such as metals and ammonia. Pure water is neutral ( $\mathrm{pH} 7$ ), but natural water in equilibrium with the atmosphere (for example, rainwater) has a $\mathrm{pH}$ value of 5.7 due to carbon dioxide dissolved in the water. As rainwater flows through soils, mineral oxides and carbonates that have been dissolved react with the water increasing $\mathrm{pH}$. The $\mathrm{pH}$ of a water also can be increased during the day by photosynthesis. 
The $\mathrm{pH}$ of streams can be decreased by inputs from acid mine drainage.

The median $\mathrm{pH}$ at the fixed sites ranged from 6.8 at Big Thompson River below Moraine Park, near Estes Park, Colorado, to 8.4 at South Platte River at North Platte, Nebraska (fig. 15). Fixed sites in agricultural land use had significantly greater $\mathrm{pH}$ than sites in forest land use. However, $\mathrm{pH}$ often was similar at sites in different land uses, and $\mathrm{pH}$ often varied substantially at sites within in a land-use class, which indicated that factors other than land use had a substantial effect on $\mathrm{pH}$. Stream standards at all the fixed sites allow a pH in the range of 6.5 to 9.0 (table 5), and all $\mathrm{pH}$ measurements were within this range. The minimum $\mathrm{pH}$ measured was 6.5 at Big Thompson River below Moraine Park, near Estes Park, Colorado, and the maximum $\mathrm{pH}$ measured was 9.1 at South Platte River at North Platte, Nebraska.

\section{Major Constituents}

Dissolved solids are a sum of all the major dissolved constituents in water and are measured by evaporating a sample of water and weighing the residue. Dissolved-solids concentrations are directly related to specific conductance because dissolved solids in the ionic form cause increased specific conductance. Dissolved-solids concentrations at the fixed sites had a pattern similar to the pattern for specific conductance; concentrations were largest at agricultural sites and smaller at urban/agricultural, urban, rangeland, and forest land-use sites. There are no State stream standards for dissolved solids, but there is a U.S. Environmental Protection Agency recommended limit for drinking water of $500 \mathrm{mg} / \mathrm{L}$ (U.S Environmental Protection Agency, 1996). Median dissolved-solids concentrations were greater than this limit at two sites that are classified for water-supply use: Cherry Creek at Denver, Colorado $(642 \mathrm{mg} / \mathrm{L})$, and South Platte River at Henderson, Colorado $(557 \mathrm{mg} / \mathrm{L})$. Dissolved solids in irrigation water can be hazardous to crops when concentrations are greater than $1,500 \mathrm{mg} / \mathrm{L}$; a median dissolvedsolids concentration was greater than this limit at one site classified for agricultural use, Lonetree Creek near Greeley, Colorado (1,540 mg/L).

Major constituents in water include major ions [bicarbonate (determined by the field measurement of alkalinity), calcium, chloride, magnesium, potassium, sodium, and sulfate], fluoride, iron and manganese, dissolved silica, and dissolved organic carbon.

Together the major ions are used to categorize the water type. The median ionic composition of water from the fixed sites is shown on a Piper diagram in figure 17. The Piper diagram (Piper, 1944) consists of two trilinear plots that show the cationic and anionic composition of the water and a diamond-shaped plot that shows the overall ionic composition of the water. Each vertex on the Piper plot represents 100 percent of a particular ion or group of ions, and the coordinates of a point plotted on the diagram add to 100 percent. Calcium and sulfate were predominant in water at agricultural sites, and these sites were well grouped in figure 17. This water type was similar to the type in alluvial water from agricultural wells along the South Platte River (B.W. Bruce, U.S. Geological Survey, written commun., 1996). Large sulfate concentrations in agricultural areas may be due to application of sulfur and sulfate in fertilizers, which may be transported to surface water through irrigation return flows. Water from urban sites also grouped together on the Piper diagram and had more sodium plus potassium and chloride than water from agricultural sites. The water composition of the urban/agricultural sites was in between the agricultural and urban sites. The forested sites (except the Clear Creek site) and the rangeland site also grouped together and had predominantly calcium bicarbonate type water. The ionic composition of water from Clear Creek at Golden, Colorado, was similar to the composition at the urban/agricultural sites and indicated that factors other than the predominant land use had a large effect at this site.

Chloride and sulfate each have a chronic standard (table 5) of $250 \mathrm{mg} / \mathrm{L}$ at all fixed sites, except for the sites in urban/agricultural and agricultural land use. Chloride is not a predominant ion at the sites, and chloride concentrations did not exceed the standard. Sulfate, however, often is the predominant anion at the fixed sites. Median sulfate concentrations (fig. 18) ranged from $1.6 \mathrm{mg} / \mathrm{L}$ at Big Thompson River below Moraine Park, near Estes Park, Colorado, to $760 \mathrm{mg} / \mathrm{L}$ at Lonetree Creek near Greeley, Colorado. The maximum concentration measured for sulfate $(1,100 \mathrm{mg} / \mathrm{L})$ also was at the Lonetree Creek site. Sulfate concentrations were largest at agricultural sites (fig. 18) and mixed urban/agricultural sites. Sulfate concentrations at urban, forest, and rangeland sites did 


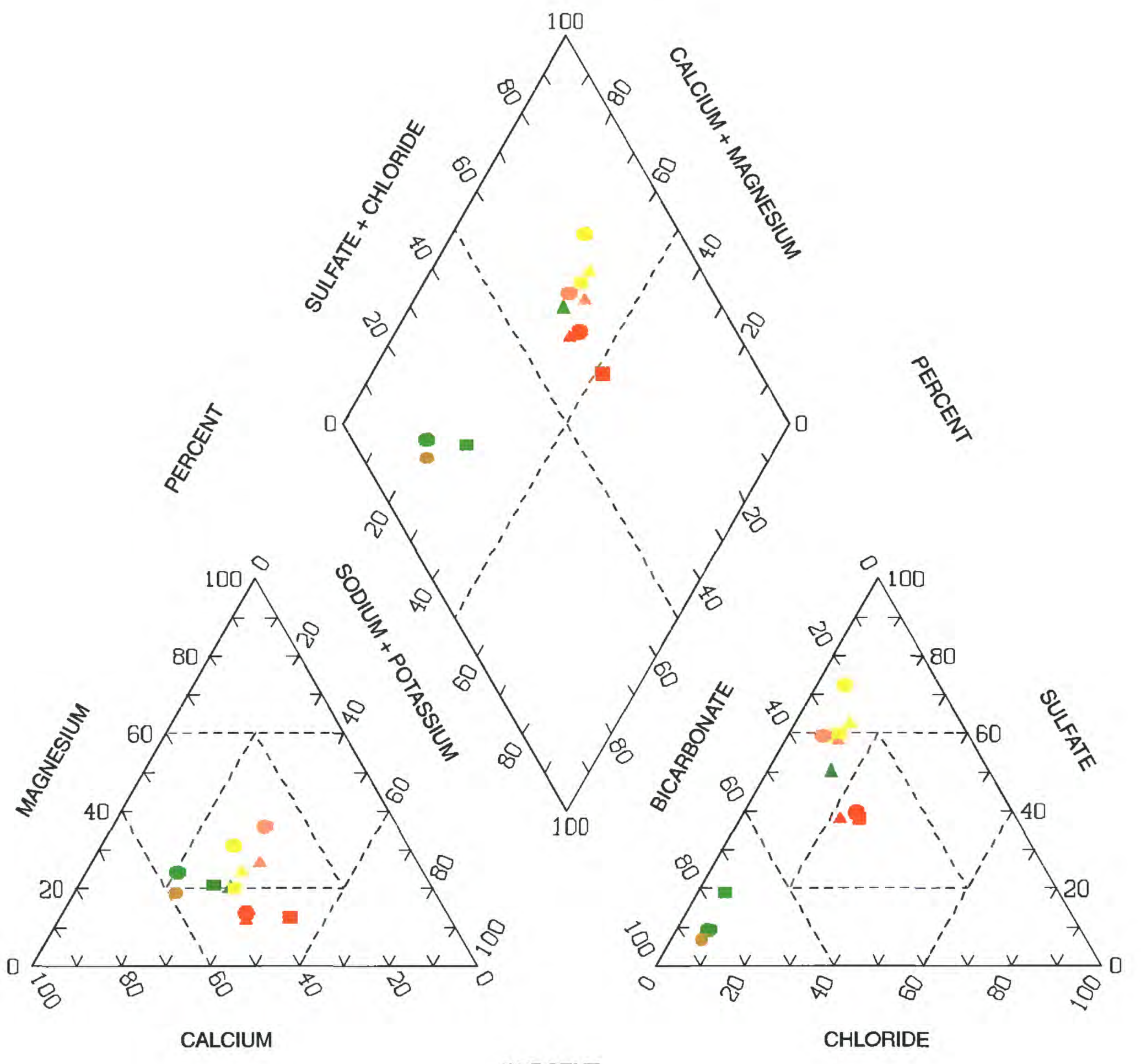

PERCENT

\section{EXPLANATION}

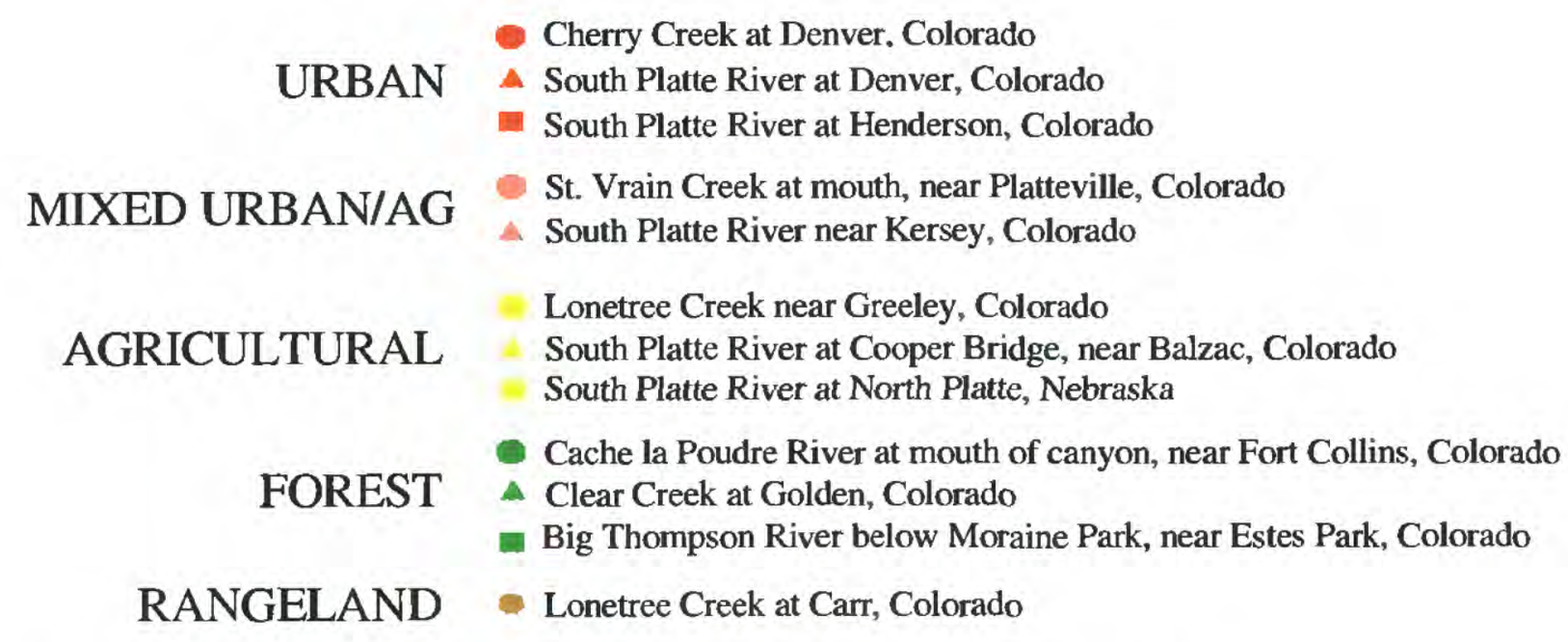

Figure 17. Piper diagram showing major-ion composition at the fixed sites. 


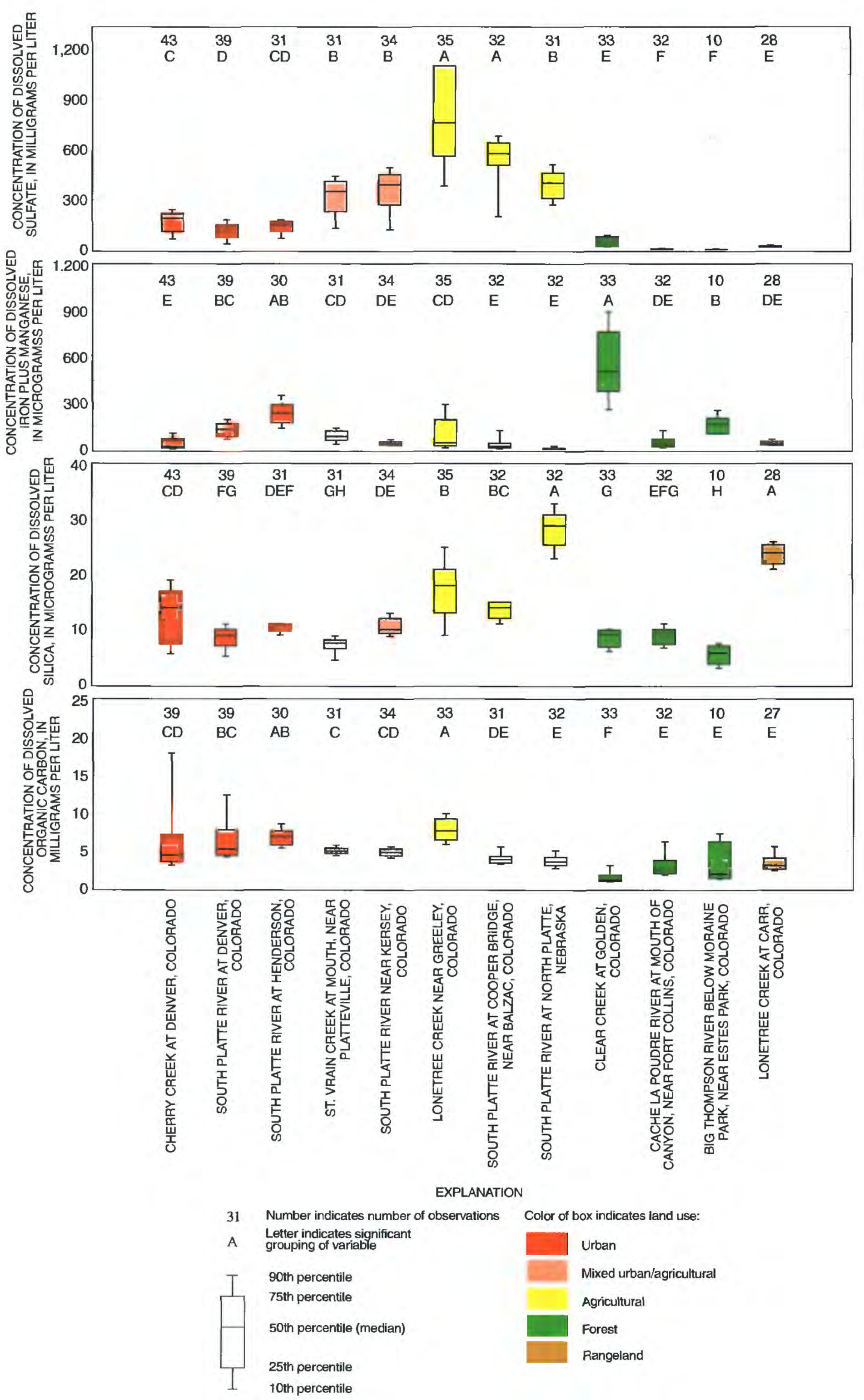

Figure 18. Distributions of concentrations of dissolved sulfate, dissolved iron plus manganese, dissolved silica, and dissolved organic carbon at the fixed sites. 
not exceed chronic standards except, for one sample at Cherry Creek at Denver, Colorado (270 mg/L).

Iron and manganese are common metals dissolved in stream water. Iron is the second most abundant metallic element in the Earth's crust (after aluminum), and manganese is the fourth most abundant'metallic element. Iron and manganese concentrations in water often are related because their sources and chemistry are similar; the two elements are common in many rocks and soils, especially clay soils. Anthropogenic sources include industrial wastes and mine drainage. The solubility of these metals in water is small, but is increased in acidic waters; acid mine drainage has elevated concentrations of iron and manganese. When $\mathrm{pH}$ increases, the metals can precipitate and form cloudy flocculates or yellow or red (iron) or brown (manganese) stains on surfaces; iron generally precipitates before manganese. Alkalinity in water also provides complexing agents for these metals, which could remove them from the dissolved state. Iron and manganese are essential elements in the metabolism of animals and plants; however, excessive concentrations are detrimental to aquatic life.

Median concentrations of iron plus manganese at the fixed sites (fig. 18) ranged from $8 \mu \mathrm{g} / \mathrm{L}$ at South Platte River at North Platte, Nebraska, to $509 \mu \mathrm{g} / \mathrm{L}$ at Clear Creek at Golden, Colorado. Concentrations of iron plus manganese generally were largest at forest and urban sites and smallest at agricultural sites, but variation in land uses was large. For example, the median concentrations of iron plus manganese at the three forest sites were $41 \mu \mathrm{g} / \mathrm{L}$ (Cache la Poudre River site), $168 \mu \mathrm{g} / \mathrm{L}$ (Big Thompson River site), and $509 \mu \mathrm{g} / \mathrm{L}$ (Clear Creek site). The large concentrations in Clear Creek were due to mine drainage in the basin. The concentrations of iron plus manganese in the Big Thompson River and in the Cache la Poudre River were dominated by iron (ratio greater than 5:1), whereas manganese predominated in Clear Creek (ratio of 1:5). Synoptic sampling along Clear Creek has indicated that iron predominated in the headwaters of Clear Creek, but manganese predominated in mine drainage in the vicinity of Idaho Springs, Colorado, and in Clear Creek downstream from Idaho Springs (R.A. Kimbrough, U.S. Geological Survey, written commun., 1996).

Stream segment standards (table 5) for iron were not exceeded, except at the Clear Creek site, where the $300-\mu \mathrm{g} / \mathrm{L}$ chronic water-supply standard was exceeded once $(360 \mu \mathrm{g} / \mathrm{L})$ during the snowmeltrunoff peak in 1995. The chronic standards for manganese $(50 \mu \mathrm{g} / \mathrm{L}$ at most sites), however, were exceeded at Cherry Creek at Denver, Colorado (maximum of $92 \mu \mathrm{g} / \mathrm{L}$ ); South Platte River at Denver, Colorado (maximum of $180 \mu \mathrm{g} / \mathrm{L}$ ); Clear Creek at Golden, Colorado (maximum of $1,600 \mu \mathrm{g} / \mathrm{L}$ ); and St. Vrain Creek at mouth, near Platteville, Colorado (maximum of $130 \mu \mathrm{g} / \mathrm{L})$.

Silica generally is dissolved in natural water in concentrations from 1 to $30 \mathrm{mg} / \mathrm{L}$ (Hem, 1985). The source of silica is the dissolution of silicate minerals, and the concentration of dissolved silica in ground water generally is related to rock type and temperature of the water. There are no State water-quality standards for silica. Median silica concentrations for the fixed sites (fig. 18) ranged from $5.7 \mathrm{mg} / \mathrm{L}$ at Big Thompson River below Moraine Park, near Estes Park, Colorado, to $29 \mathrm{mg} / \mathrm{L}$ at South Platte River at North Platte, Nebraska. Silica concentrations were largest at agricultural and rangeland sites and were smaller and similar at urban, forest, and mixed urban/agricultural sites. These unusual groupings indicated that factors other than land use may be important in determining silica concentrations. Silica concentrations were significantly smaller at crystalline bedrock sites than at sedimentary rock sites. Sites where ground water contributed substantially to streamflow tended to have the largest silica concentrations. Silica concentrations in alluvial ground water from agricultural wells along the South Platte River had a median value of $30.5 \mathrm{mg} / \mathrm{L}$ (B.W. Bruce, U.S. Geological Survey, written commun., 1996).

Dissolved organic carbon consists of a variety of complex organic molecules that are broadly classified as humic and fulvic acids and that are generally derived in the natural environment from the decomposition of plant debris. Anthropogenic sources include wastes from humans, domestic animals, and farm animals and increased vegetative inputs from plant cultivation. Dissolved organic carbon can affect the chemistry of stream water by adsorption of metals and organic compounds and by participation in microbially mediated reactions. Although there are no State stream standards for dissolved organic carbon, dissolved organic carbon can affect the production of toxic by-products from chlorination of drinking water.

Median concentrations of dissolved organic carbon at the fixed sites ranged from $1.2 \mathrm{mg} / \mathrm{L}$ at Clear Creek at Golden, Colorado, to $7.5 \mathrm{mg} / \mathrm{L}$ at Lonetree 
Creek near Greeley, Colorado (fig. 18). Urban, agricultural, and mixed urban/agricultural land-use sites had significantly larger concentrations of dissolved organic carbon than forest and rangeland sites, but variability in land uses was large.

\section{Nutrients}

Nutrients are essential substances for plant growth and include nitrogen and phosphorus species. For this study, laboratory analyses were done for five nitrogen species and three phosphorus species (table 1). The total nitrogen concentration in water can be calculated as the sum of dissolved nitrite plus nitrate and total organic nitrogen plus ammonia. Excessive concentrations of nutrients in rivers, lakes, and reservoirs can accelerate the growth of algae and other aquatic plants, causing problems such as clogged pipelines, fishkills, and restricted recreation. Natural sources of nutrients include phosphate minerals in rocks and soils and breakdown products from the decomposition of organic matter; anthropogenic sources include phosphate detergents, domestic wastewater, and fertilizers.

Median total nitrogen concentrations ranged from $0.22 \mathrm{mg} / \mathrm{L}$ at Big Thompson River below Moraine Park, near Estes Park, Colorado, to $9.0 \mathrm{mg} / \mathrm{L}$ at Lonetree Creek near Greeley, Colorado (fig. 19). Total nitrogen concentrations were large in urban, mixed urban/agricultural, and agricultural land uses and small in forest and rangeland land uses. The relative proportions of the nitrogen species varied among the fixed sites (fig. 20). Ammonia constituted more than 10 percent of the total nitrogen concentration at only one site, South Platte River at Henderson, Colorado, which is located downstream from a wastewatertreatment plant. At the remaining sites, nitrite plus nitrate predominated although total organic nitrogen was relatively more common at forest and rangeland sites.

Median total phosphorus concentrations ranged from $0.01 \mathrm{mg} / \mathrm{L}$ at Big Thompson River below Moraine Park, near Estes Park, Colorado, to $1.6 \mathrm{mg} / \mathrm{L}$ at South Platte River at Henderson, Colorado (fig. 19). Total phosphorus concentrations were largest at urban and mixed urban/agricultural sites. In the South Platte River, total nitrogen and total phosphorus concentrations were largest at South Platte River at Henderson, Colorado, which is downstream from a major wastewater-treatment plant. Nutrient concentrations in the
South Platte River decreased downstream from Henderson, Colorado, primarily due to removal of nutrientrich water from the river by irrigation ditches and to replacement by ground-water inflow, which has smaller nutrient concentrations (Litke, 1996).

Because phosphorus generally is the controlling factor for reservoir eutrophication, the USEPA has recommended that total phosphorus concentrations be less than $0.1 \mathrm{mg} / \mathrm{L}$ in flowing rivers and that phosphates be less than $0.05 \mathrm{mg} / \mathrm{L}$ where rivers enter lakes and reservoirs (U.S. Environmental Protection Agency, 1986). Phosphorus concentrations exceeded $0.1 \mathrm{mg} / \mathrm{L}$ at all urban, agricultural, and mixed urban/agricultural fixed sites and at Clear Creek at Golden, Colorado; the minimum measured phosphorus concentration exceeded $0.1 \mathrm{mg} / \mathrm{L}$ at most of these sites. The USEPA also has set a maximum contaminant level (MCL) of $10 \mathrm{mg} / \mathrm{L}$ for nitrate, as nitrogen, in drinking water (U.S. Environmental Protection Agency, 1990). This MCL was exceeded once at an urban site classified for drinking-water use (10.8 $\mathrm{mg} / \mathrm{L}$ at South Platte River at Denver, Colorado) and several times at an agricultural site not classified for drinking-water use (maximum of $12.9 \mathrm{mg} / \mathrm{L}$ at Lonetree Creek near Greeley, Colorado). Stream standards for nitrite range from 0.05 to $1.0 \mathrm{mg} / \mathrm{L}$ (table 5). The standard for nitrite was exceeded only at South Platte River at Denver, Colorado. Stream standards for un-ionized ammonia range from 0.02 to $0.1 \mathrm{mg} / \mathrm{L}$ (table 5). Un-ionized ammonia concentrations can be calculated based on ammonia concentration, $\mathrm{pH}$, and water temperature. The stream standard was exceeded once at South Platte River at Denver, Colorado, and several times at South Platte River at Henderson, Colorado.

\section{Suspended sediment}

Streams transport particulate material that is eroded from the land surface as suspended sediment; this sediment occurs in sizes from clay and silt $(0.00024-0.062 \mathrm{~mm})$ to sand $(0.062-2.00 \mathrm{~mm})$ to larger gravel and cobbles. Sediment is transported as: (1) Suspended load, where sediment at any given time is in suspension as a colloid or is maintained in suspension by upward components of turbulent currents; or (2) bedload, where sediment is in almost continuous contact with the streambed as the sediment moves by bouncing, skipping, and rolling. Suspended- 

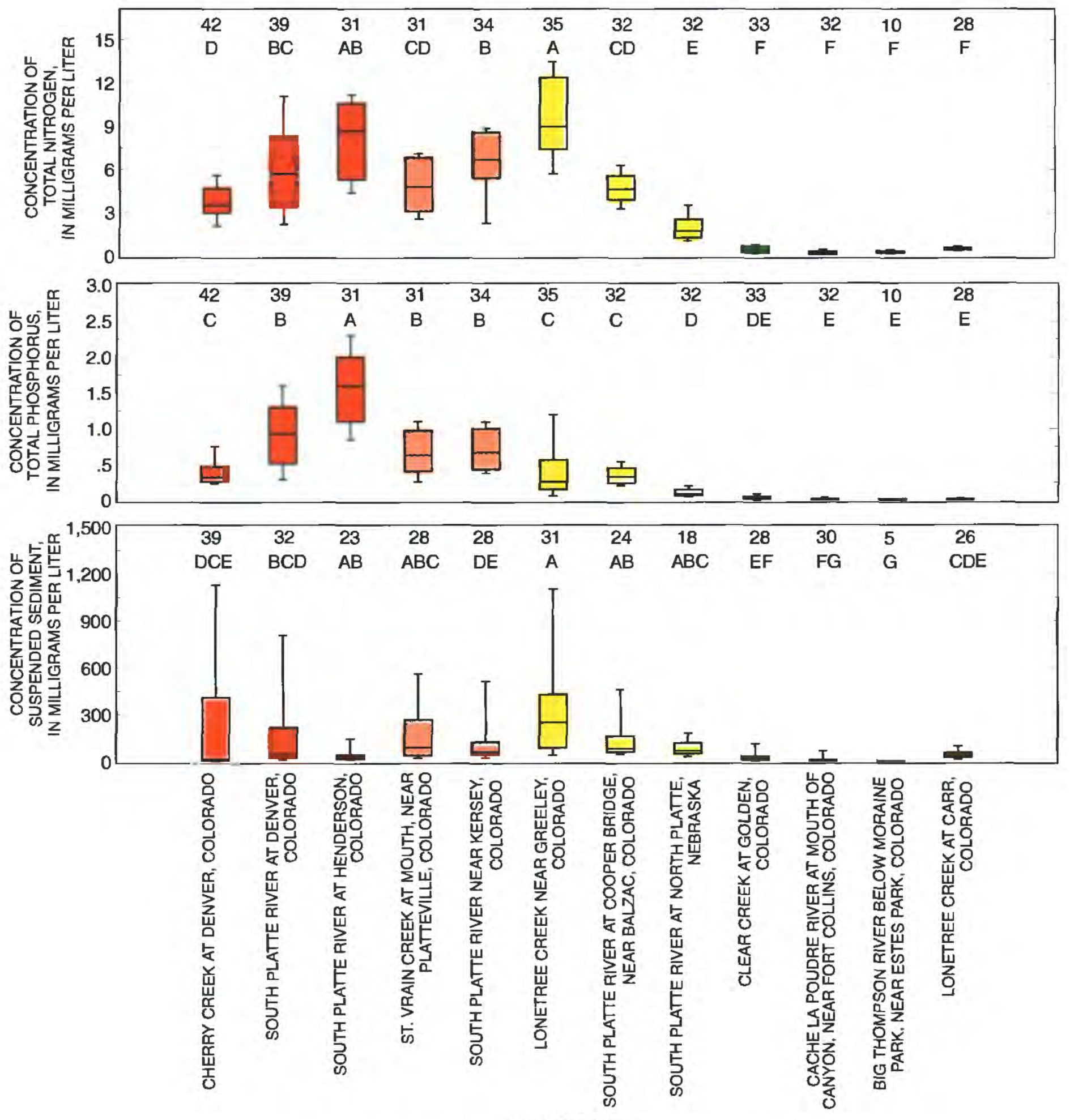

EXPLANATION

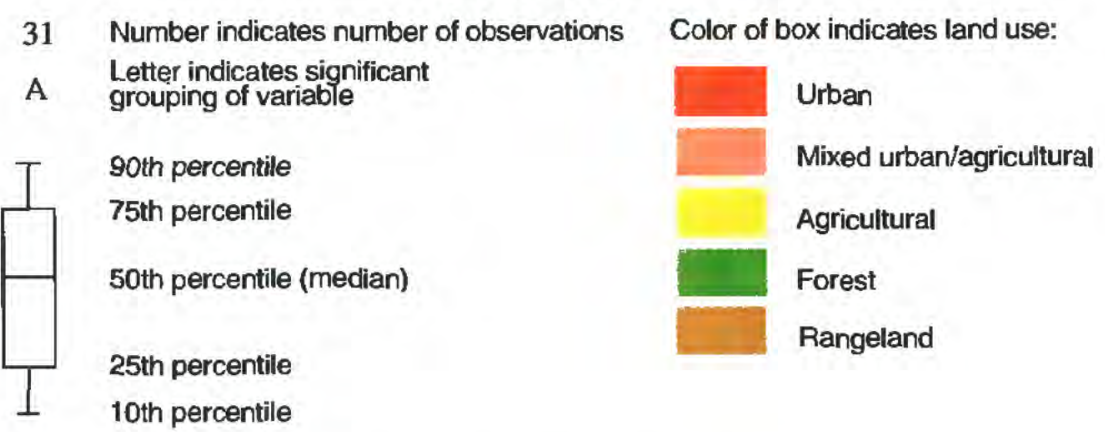

Figure 19. Distributions of concentrations of total nitrogen, total phosphorus, and suspended sediment at the fixed sites. 

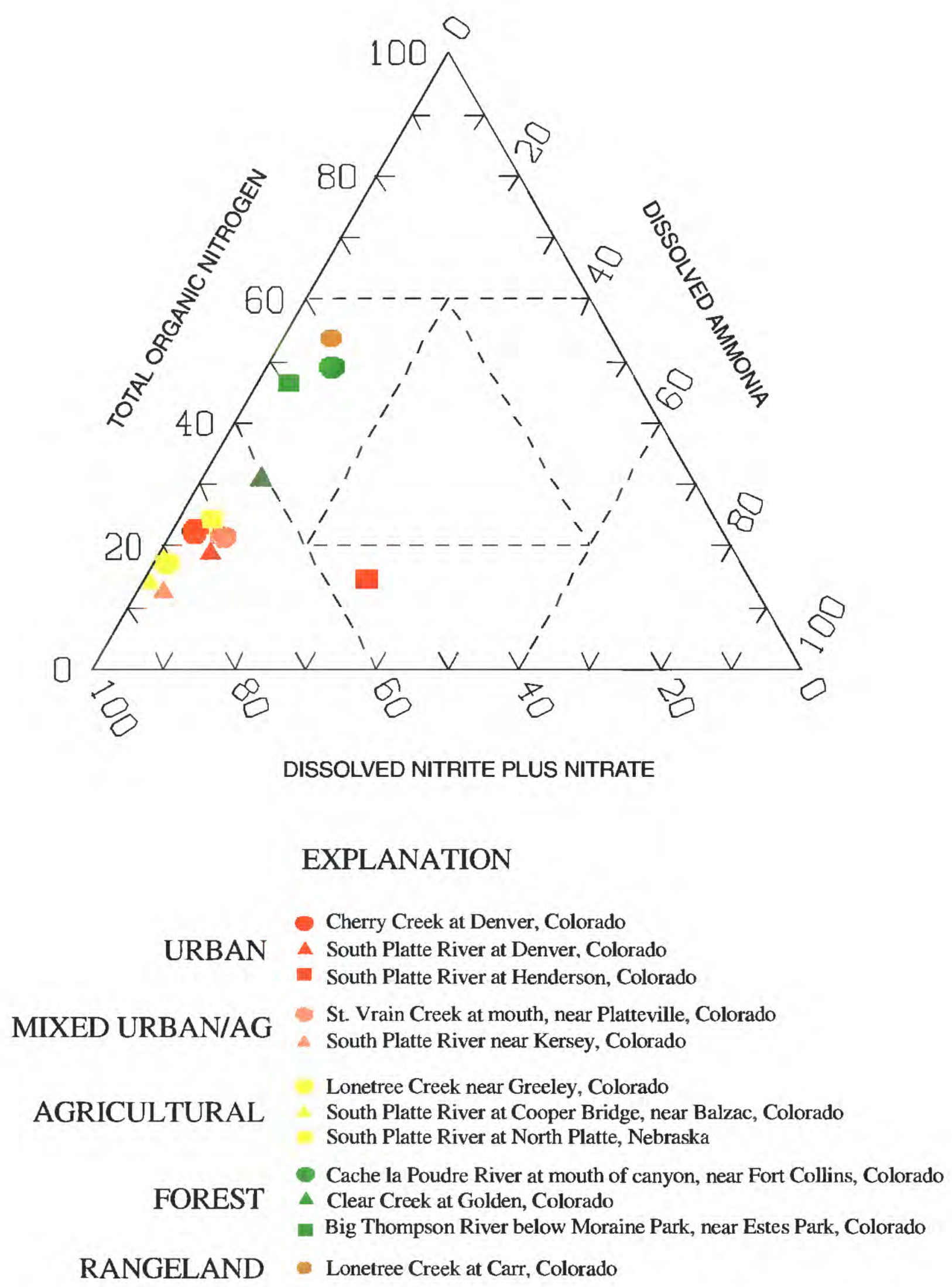

Figure 20. Trilinear diagram showing median proportional composition of total nitrogen concentration at the fixed sites. 
sediment samples were collected at fixed sites as part of regular water-quality sampling and are discussed in this section. Suspended sediment is a water-quality concern because it needs to be removed from drinking water before chlorination can be effective. Suspended sediment has adverse health effects on fish, and when suspended sediment settles, it can blanket the bottom of water bodies and damage invertebrate populations and block gravel spawning beds; however, there are no numeric water-quality standards for suspended sediment, but the basic State standards mandate that streams be free from human-caused suspended sediment that can settle to form bottom deposits detrimental to the beneficial uses of the stream (Colorado Department of Health, 1993b).

Median suspended-sediment concentrations at the fixed sites ranged from $1 \mathrm{mg} / \mathrm{L}$ at Big Thompson River below Moraine Park, near Estes Park, Colorado, to $250 \mathrm{mg} / \mathrm{L}$ at Lonetree Creek near Greeley, Colorado (fig. 19). Suspended-sediment concentrations were largest for sites in agricultural and mixed urban/agricultural land use and smallest for sites in forest land use. The largest measured suspended-sediment concentration $(4,540 \mathrm{mg} / \mathrm{L})$ occurred during rainfall runoff at the small agricultural basin (Lonetree Creek near Greeley site); a large concentration of $2,400 \mathrm{mg} / \mathrm{L}$ also occurred at the small urban site (Cherry Creek site) during rainfall runoff.

The shape of the boxplots for suspended sediment in figure 19 indicated that the distribution of values at the fixed sites was skewed (the median line is not centered in the box, and the upper whisker is long); small concentrations were most common, but extreme large concentrations occurred during large streamflows. Large concentrations generally are due to an increase in sediment input during runoff events from overland runoff and bank erosion and to an increase in stream power to resuspend and carry sediment during large streamflows. Suspended sediment at the fixed sites consisted mostly of clay and silt (median of 79 percent clay and silt), but the proportion of sand increased during high streamflows. Suspended sediment is one of a few water-quality constituents that increased in proportion to streamflow; other constituents that increased included suspended organic nitrogen, suspended phosphorus, and suspended organic carbon.

\section{Relation of Land Use to Concentrations}

Previous sections of this report have discussed differences in median concentrations among the fixed sites. The differences often appeared to be related to land use, which is a principal hypothesis of the NAWQA study design; namely that water quality is different for different land uses. This hypothesis can be tested for fixed sites in the South Platte River Basin by combining data for fixed sites according to land use and then testing for significant differences using the same statistical techniques discussed at the beginning of the "Concentrations" section of this report. The results of the multiple comparison tests on fixed sites grouped by land use are listed in table 6 . In this table, the letter ' $A$ ' is used to represent the land use with the largest median concentration (or value) and successive letters represent land uses with correspondingly smaller median concentrations. If two land uses each are labeled with the letter ' $A$,' then they are tied for the largest median concentration. Land use was a statistically significant grouping variable for all the water-quality constituents. For some constituents (water temperature, specific conductance, dissolved solids, and sodium), median concentrations in each land use were significantly different from all others (each land use has its own letter in table 6). For other constituents (for example, nitrite plus nitrate), there were as few as two different significant groups.

Rangeland had the largest median concentrations (or was tied for the largest concentrations) for only two constituents: dissolved oxygen and silica (table 6). Large concentrations of dissolved oxygen and silica generally are not water-quality concerns; the data, therefore, indicated that rangeland use had a smaller effect on water quality than did the other land uses. However, a large rainfall runoff event did not occur at the rangeland fixed site during the 1993-95 study period; such an event has the capability of having a substantial effect on water quality, particularly for suspended sediment.

Forest land use had the largest median concentrations (or was tied for the largest concentrations) for only three constituents: dissolved oxygen, iron, and manganese (table 6). Large dissolved-oxygen concentrations generally are not a water-quality concern, but large iron and manganese concentrations can be a concern, especially because other trace metals often are associated with iron and manganese in water from mining land use. Forest land use generally formed a 
Table 6. Summary of water quality for major land-use categories

[Letter indicates significantly different median concentration as determined by using Tukey multiple comparison test at significance level of 0.05 ; A represents highest value or concentration, successive letters correspondingly smaIler median concentrations]

\begin{tabular}{|c|c|c|c|c|c|}
\hline \multirow[b]{2}{*}{ Water-quality constituent } & \multicolumn{5}{|c|}{ Land use } \\
\hline & Urban & $\begin{array}{l}\text { Mixed urban/ } \\
\text { agricultural }\end{array}$ & Agricultural & Forest & Rangeland \\
\hline \multicolumn{6}{|c|}{ Field measurements } \\
\hline Water temperature (hourly for 1 year) & A & B & $\mathrm{C}$ & $\mathrm{E}$ & $\mathrm{D}$ \\
\hline Dissolved oxygen & $\mathrm{C}$ & $\mathrm{BC}$ & $\mathrm{AB}$ & A & $\mathrm{AB}$ \\
\hline $\mathrm{pH}$ & $\mathrm{C}$ & $\mathrm{BC}$ & A & $\mathrm{D}$ & $\mathrm{D}$ \\
\hline Specific conductance & $\mathrm{C}$ & B & A & $\mathrm{E}$ & $\mathrm{D}$ \\
\hline \multicolumn{6}{|c|}{ Laboratory analyses } \\
\hline \multicolumn{6}{|l|}{ Major constituents: } \\
\hline Dissolved solids & $\mathrm{C}$ & B & A & $\mathrm{E}$ & $\mathrm{D}$ \\
\hline \multicolumn{6}{|l|}{ Major ions and metals: } \\
\hline Calcium & $\mathrm{C}$ & B & A & $\mathrm{D}$ & $\mathrm{C}$ \\
\hline Chloride & A & B & A & $\mathrm{D}$ & $\mathrm{C}$ \\
\hline Fluoride & $\mathrm{AB}$ & A & B & $\mathrm{C}$ & $\mathrm{D}$ \\
\hline Iron & B & $\mathrm{C}$ & D & A & $\mathrm{BC}$ \\
\hline Magnesium & B & A & $\mathrm{A}$ & $\mathrm{C}$ & $\mathrm{B}$ \\
\hline Manganese & A & $\mathrm{AB}$ & $\mathrm{C}$ & $\mathrm{ABC}$ & $\mathrm{BC}$ \\
\hline Potassium & B & B & A & $\mathrm{C}$ & $\mathrm{B}$ \\
\hline Silica & $\mathrm{C}$ & $\mathrm{CD}$ & B & $\mathrm{D}$ & A \\
\hline Sodium & $\mathrm{C}$ & $\mathrm{B}$ & A & $\mathrm{E}$ & $\mathrm{D}$ \\
\hline Sulfate & $\mathrm{C}$ & B & A & $\mathrm{D}$ & $\mathrm{D}$ \\
\hline \multicolumn{6}{|l|}{ Organic carbon: } \\
\hline Suspended & B & A & $\mathrm{AB}$ & $\mathrm{C}$ & $\mathrm{C}$ \\
\hline Dissolved & A & A & A & B & B \\
\hline \multicolumn{6}{|l|}{ Nutrients: } \\
\hline \multicolumn{6}{|l|}{ Nitrogen: } \\
\hline Total organic nitrogen plus ammonia & A & A & B & $\mathrm{C}$ & $\mathrm{C}$ \\
\hline Dissolved organic nitrogen plus ammonia & A & A & B & $\mathrm{C}$ & $\mathrm{C}$ \\
\hline Ammonia & A & A & B & $\mathrm{C}$ & $\mathrm{C}$ \\
\hline Nitrite & A & A & $\mathrm{B}$ & $\mathrm{C}$ & $\mathrm{C}$ \\
\hline Nitrite plus nitrate & A & A & A & B & B \\
\hline Suspended nitrogen (calculated) & A & A & A & B & B \\
\hline Total nitrogen (calculated) & A & A & A & B & B \\
\hline \multicolumn{6}{|l|}{ Phosphorus: } \\
\hline Total & A & A & B & $\mathrm{C}$ & $\mathrm{C}$ \\
\hline Total dissolved & $\mathrm{A}$ & A & $\mathrm{B}$ & $\mathrm{C}$ & $\mathrm{C}$ \\
\hline Orthophosphate & A & A & B & $\mathrm{C}$ & $\mathrm{C}$ \\
\hline Suspended phosphorus (calculated) & A & A & A & B & B \\
\hline Suspended sediment & B & A & A & $\mathrm{C}$ & B \\
\hline
\end{tabular}

unique water-quality group (in table 6, forest land use usually does not share letters with other land uses), except for nutrients, where forest land use often grouped with rangeland. Although forest land use generally formed a unique water-quality group, substantial differences in concentrations occurred within forest land use for nutrients and iron plus manganese (as discussed in the "Concentrations" section of this report), corresponding to the magnitude of wastewater-treatment-plant discharges and mining land use upstream from the three forest land-use fixed sites. Dissolved-solids and suspendedsediment concentrations also varied within forest land use, corresponding to the level of development in 
the three basins. These differences indicated that secondary land uses had a substantial effect on water quality at forest land-use sites.

Urban land use had the largest median concentrations or values (or was tied for the largest concentrations or values) for 16 constituents (table 6 ), but only 1 constituent (water temperature) was uniquely largest in urban land use. Urban land use often grouped with mixed urban/agricultural land use, which indicated that the urban contribution to mixed urban/agricultural land use was substantial. Most of the variability within urban land use (see figs. 18 and 19) occurred for concentrations of nutrients, dissolved iron plus manganese, and dissolved organic carbon, and the differences corresponded to the magnitude of inputs from wastewater-treatment plants upstream from the three urban land-use fixed sites. These differences indicated that wastewater-treatment-plant discharges were a substantial factor in determining urban water quality.

Agricultural land use had the largest median concentrations or values (or was tied for the largest concentrations or values) for 17 constituents (table 6). Agricultural land use was a unique group for 10 constituents, and had the largest median concentrations or values for seven of these $(\mathrm{pH}$, specific conductance, dissolved solids, calcium, potassium, sodium, and sulfate). Agricultural land use was tied with mixed urban/agricultural land use for the largest concentrations of suspended sediment, and because urban land use had smaller concentrations, it may be assumed that agricultural land use was the primary source of suspended sediment. There was substantial variability in concentrations within agricultural land use.

Concentrations of most constituents (figs. 18 and 19) were largest at Lonetree Creek near Greeley, Colorado; second largest at South Platte River at Cooper Bridge, near Balzac, Colorado; and smallest at South Platte River at North Platte, Nebraska. Local land use is similar at these sites, but the hydrology is quite different. The agricultural fixed site on Lonetree Creek derives all of its water from local agricultural sources. The fixed sites on the South Platte River near Balzac and at North Platte derive substantial water from local agricultural return flows, but also derive water from mixed urban/agricultural land-use areas further upstream. Also, the agricultural return flows to the sites on the South Platte River primarily are groundwater return flows, so the resultant water quality is affected by regional aquifer water quality and by processes that change ground-water quality as it migrates from fields to the river.

Mixed urban/agricultural land use had the largest median concentrations (or was tied for the largest concentrations) for 17 constituents (table 6). Overall, mixed urban/agricultural land use had larger median concentrations (more A's and B's in table 6) than any other land use. The relatively poor water quality in this land use is due to the combined effects of urban and agricultural land use. Variability of concentrations within this land use was small (figs. 15, 18 , and 19), which indicated that the integration of combined land uses produces similar water quality in a medium-sized (St. Vrain Creek at mouth, near Platteville, Colorado) and a large-sized (South Platte River near Kersey, Colorado) basin.

\section{Temporal Trends in Concentrations}

Long-term temporal trends in concentrations can be evaluated at fixed sites by combining NAWQA data with earlier data collected by the USGS and other agencies. The most commonly sampled fixed sites are those along the South Platte River (Denver, Henderson, Kersey, and Balzac in Colorado and North Platte in Nebraska), and data for these sites from about 1950 are available from the USEPA Storage and Retrieval (STORET) system. However, not all sites have data from 1950, and some sites have gaps in the record; for this comparison, 1963-96 was selected because these years had the best data overlap between sites. Sufficient data for trend analysis are available only for several commonly analyzed constituents, namely dissolved oxygen, specific conductance, hardness, chloride, sulfate, nitrate, and total phosphorus. The USGS data for total phosphorus for 1980-81 were excluded from this analysis because of a positive bias identified in the analytical results from that time period.

The seasonal Kendall test was used to detect trends. This nonparametric test is applicable to waterquality data because it is suitable for data that are not normally distributed and because it accounts for seasonal variability in data by only comparing data collected during the same season. A computer program developed by the USGS called EStimate TREND (ESTREND) (Schertz and others, 1991) was used to compute the test statistics. This program also has the capability of adjusting concentrations for 
streamflow before performing the trend tests, which can reduce variability due to such factors as climatic conditions (wet years and dry years) and sampling bias (an unbalanced focus on high or low streamflows). A level of significance of 0.05 was selected to evaluate the results of the trend tests; that is, the test will be correct 95 percent of the time in indicating no trend when there actually is no trend.

The results of the seasonal Kendall test for trends are listed in table 7. Three fixed sites on the South Platte River (sites at Henderson, Colorado, near Kersey, Colorado, and at North Platte, Nebraska) had a significant upward trend in instantaneous flow (flow measured at time of sample collection). A data set of monthly mean streamflows for 1963-96 also was tested for trends for comparison with the results from instantaneous flows, and an upward trend in flow was detected at all five sites along the South Platte River. Increasing flows in the South Platte River Basin probably are due to increasing amounts of water imported into the basin via transmountain diversions.

Most water-quality constituents had statistically significant trends. The results of trend testing were the same for flow-adjusted data and non-flow-adjusted data, except that the magnitude of change was larger for the non-flow-adjusted data. Upward trends in dissolved-oxygen concentrations occurred at the fixed sites at Denver, Colorado, and at North Platte,
Nebraska, whereas no trend occurred at Henderson, Colorado (table 7). Upward trends for dissolved oxygen might be due to improved wastewatertreatment processes or to a decrease in wastewater discharges to streams. There was a downward trend in specific conductance at upstream sites (Denver, Henderson, and Kersey in Colorado), but no trend or an upward trend at downstream sites (near Balzac, Colorado, and at North Platte, Nebraska). Constituents that contribute to specific conductance (hardness, chloride, and sulfate) also had downward trends, except for an upward trend in chloride near Balzac. Because these trends occur for flow-adjusted data, the results may indicate that the sources of these constituents have declined, except in the lower river where salinity problems may be on the increase. Nitrate concentrations had upward trends at all sites along the river from Henderson downstream to North Platte (insufficient data were available to test for a nitrate trend at Denver). Increasing nitrate concentrations were particularly evident near Balzac (table 7 and fig. 21), where the increase was about 4 percent per year. The increase in nitrate concentrations might be due to increasing concentrations from wastewater-treatment plants as nitrification facilities are installed or from increased nitrates from agricultural sources through irrigation return flows. There were no trends for total phosphorus concentrations (table 7 ).

Table 7. Historical trends in selected water-quality constituents at the fixed sites along the South Platte River, 1963-96

[Significant trends determined by use of seasonal Kendall test at significance level of 0.05 ; $\Uparrow$, upward trend; $\Downarrow$, downward trend; $\Leftrightarrow$, no trend; $\bullet$, insufficient data for trend test]

\begin{tabular}{|c|c|c|c|c|c|c|c|c|c|}
\hline \multirow[b]{2}{*}{ Site name } & \multicolumn{9}{|c|}{ Result of seasonal Kendall trend test for constituent } \\
\hline & $\begin{array}{l}\text { Monthly } \\
\text { mean } \\
\text { streamflow }\end{array}$ & $\begin{array}{l}\text { Instantaneous } \\
\text { streamflow }\end{array}$ & $\begin{array}{l}\text { Dissolved } \\
\text { oxygen }\end{array}$ & $\begin{array}{c}\text { Specific } \\
\text { conductance }\end{array}$ & Hardness & Chloride & Sulfate & Nitrate & $\begin{array}{c}\text { Total } \\
\text { phosphorus }\end{array}$ \\
\hline $\begin{array}{l}\text { South Platte River at } \\
\text { Denver, Colorado }\end{array}$ & $\Uparrow$ & $\bullet$ & $\Uparrow$ & $\Downarrow$ & $\bullet$ & $\bullet$ & $\bullet$ & $\bullet$ & $\bullet$ \\
\hline $\begin{array}{l}\text { South Platte River at } \\
\text { Henderson, Colorado }\end{array}$ & $\Uparrow$ & $\Uparrow$ & $\Leftrightarrow$ & $\Downarrow$ & $\downarrow$ & $\Downarrow$ & $\Leftrightarrow$ & $\Uparrow$ & $\Leftrightarrow$ \\
\hline $\begin{array}{l}\text { South Platte River } \\
\text { near Kersey, Colorado }\end{array}$ & $\Uparrow$ & $\Uparrow$ & • & $\Downarrow$ & $\Downarrow$ & • & $\Downarrow$ & $\Uparrow$ & $\Leftrightarrow$ \\
\hline $\begin{array}{l}\text { South Platte River at } \\
\text { Cooper Bridge, } \\
\text { near Balzac, Colorado }\end{array}$ & $\Uparrow$ & • & • & $\Leftrightarrow$ & $\Downarrow$ & $\Uparrow$ & $\Downarrow$ & $\Uparrow$ & $\Leftrightarrow$ \\
\hline $\begin{array}{l}\text { South Platte River at } \\
\text { North Platte, } \\
\text { Nebraska }\end{array}$ & $\Uparrow$ & $\Uparrow$ & $\Uparrow$ & $\Uparrow$ & • & - & • & $\Uparrow$ & - \\
\hline
\end{tabular}




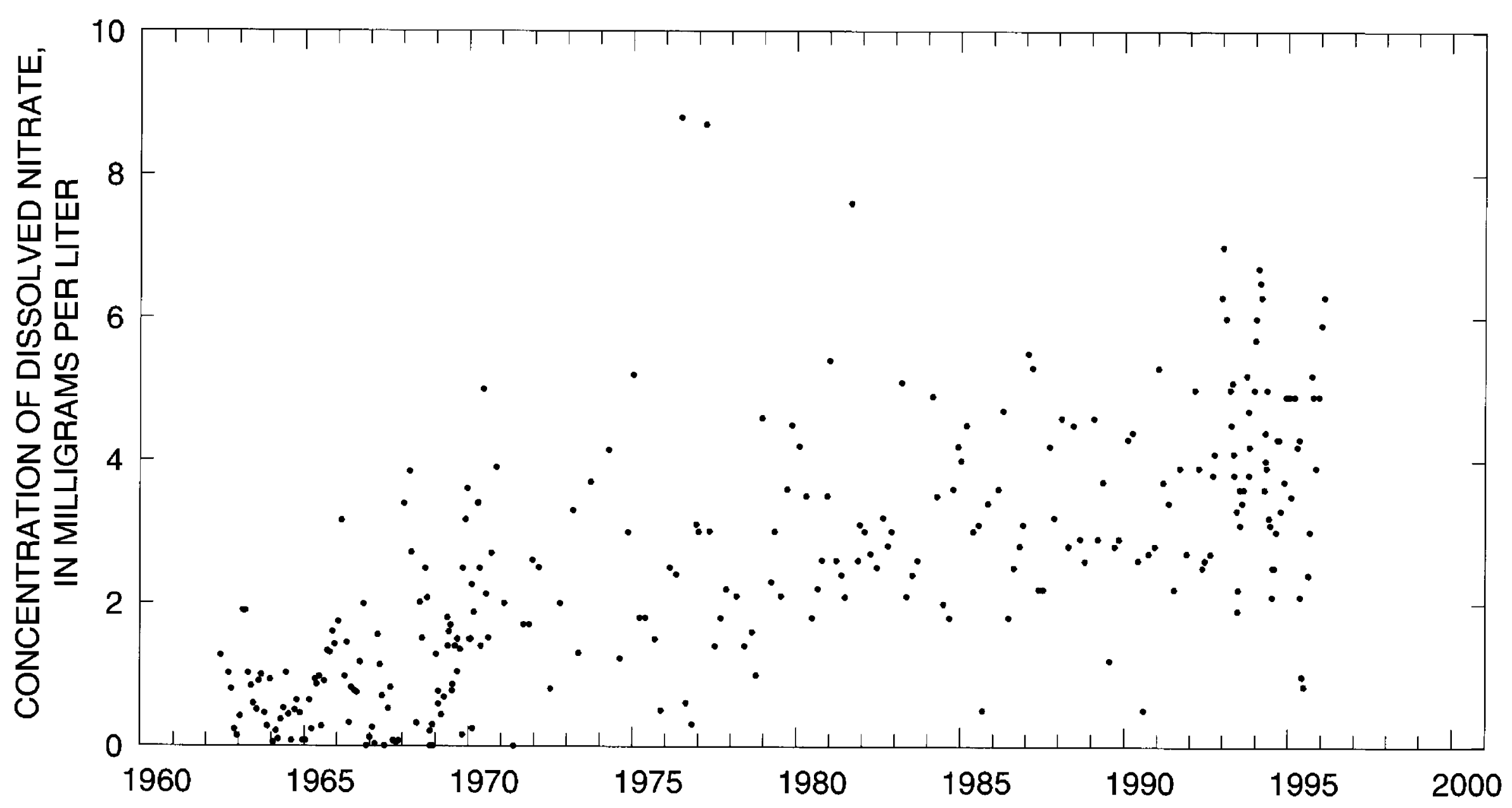

Figure 21. Concentrations of dissolved nitrate at South Platte River at Cooper Bridge, near Balzac, Colorado, 1963-96.

\section{Loads}

Daily loads for dissolved solids, total nitrogen, total phosphorus, and suspended sediment were estimated for 11 of the 12 fixed sites for the study period (March 1993 to September 1995) using daily mean streamflow data and constituent-concentration data from the fixed-site sampling. Daily loads were calculated by multiplying daily mean streamflow by a constituent concentration estimated for each day. Concentrations were estimated for each day by using a linear time-based interpolation between concentrations on sampled dates, modified by discharge-based interpolation during storms. Daily loads were summed for October 1993 through September 1995 so that a mean annual load could be calculated for the 2 water years (table 8). Mean annual loads for the four constituents were smallest at Lonetree Creek at Carr, Colorado, where mean streamflow was smallest during the study period (table 2); and mean annual loads for these constituents were largest where mean streamflow was largest, at South Platte River near Kersey, Colorado ( 810,000 tons of dissolved solids, 6,400 tons of total nitrogen, 880 tons of total phosphorus, and 510,000 tons of suspended sediment).
The downstream pattern of loads along the South Platte River was similar for the four constituents; loads increased from Denver to Kersey, Colorado, and decreased from Kersey to North Platte, Nebraska. Between Kersey and North Platte, totalnitrogen and total-phosphorus loads decreased by a factor of about 5. Synoptic nutrient sampling along the South Platte River has indicated that large proportions of the nitrogen and phosphorus loads are removed from the river by irrigation ditches, whereas smaller loads are added to the river by ground-water discharge to the river (Litke, 1996). Between Kersey and North Platte, dissolved-solids loads decreased by a substantially smaller factor (about 1.4) than did nitrogen and phosphorus loads, which indicated that dissolvedsolids loads added to the river in this segment are large compared to the inputs of nitrogen and phosphorus.

It is common to standardize loads between basins by calculating basin yield, which is load divided by contributing drainage area. However, this standardization is not meaningful for most fixed sites in the South Platte River Basin because diversion ditches remove varying quantities of water and load from the streams. It is more meaningful to compare loads at pairs of fixed sites that have similar characteristics. The sites at Cherry Creek at Denver, Colorado, 
Table 8. Mean annual loads at the fixed sites for selected water-quality constituents

$[<$, less than]

\begin{tabular}{lrrrr}
\hline \multicolumn{1}{c}{ Site name } & \multicolumn{3}{c}{$\begin{array}{c}\text { Mean annual load (water years 1994-95) } \\
\text { (tons) }\end{array}$} \\
\cline { 2 - 5 } & $\begin{array}{c}\text { Dissolved } \\
\text { solids }\end{array}$ & $\begin{array}{c}\text { Total nitrogen, } \\
\text { as nitrogen }\end{array}$ & $\begin{array}{c}\text { Total } \\
\text { phosphorus, } \\
\text { as phosphorus }\end{array}$ & $\begin{array}{c}\text { Suspended } \\
\text { sediment }\end{array}$ \\
\hline Cherry Creek at Denver, Colorado & 15,000 & 78 & 11 & 5,600 \\
South Platte River at Denver, Colorado & 120,000 & 1,400 & 230 & 150,000 \\
Clear Creek at Golden, Colorado & 19,000 & 100 & 26 & 79,000 \\
South Platte River at Henderson, Colorado & 240,000 & 3,300 & 610 & 180,000 \\
St. Vrain Creek at mouth, near Platteville, Colorado & 170,000 & 1,100 & 170 & 170,000 \\
Cache la Poudre River at mouth of canyon, & 16,000 & 94 & 6 & 10,000 \\
$\quad$ near Fort Collins, Colorado & 180 & $<1$ & $<1$ & 24 \\
Lonetree Creek at Carr, Colorado & 15,000 & 88 & 4 & 5,000 \\
Lonetree Creek near Greeley, Colorado & 810,000 & 6,400 & 880 & 510,000 \\
South Platte River near Kersey, Colorado & 630,000 & 3,000 & 430 & 380,000 \\
South Platte River at Cooper Bridge, & & & & 180,000 \\
$\quad$ near Balzac, Colorado & 600,000 & 1,300 & 180 & 1 \\
South Platte River at North Platte, Nebraska & & & & \\
\hline
\end{tabular}

and Lonetree Creek near Greeley, Colorado, were similar in magnitude of mean streamflow during the study period $\left[28 \mathrm{ft}^{3} / \mathrm{s}\right.$ and $15 \mathrm{ft}^{3} / \mathrm{s}$ respectively (table 2)]. Loads of dissolved solids, total nitrogen, and suspended sediment at these two sites were quite similar (table 8), which indicates that urban land use (Cherry Creek) and agricultural land use (Lonetree Creek) were both sources for these constituents. There was about one-half as much water in Lonetree Creek than in Cherry Creek, but concentrations of dissolved solids, total nitrogen, and suspended sediment were correspondingly larger in Lonetree Creek. Totalphosphorus loads were twice as large at the urban site than at the agricultural site, which indicates that urban land use was a more important source of phosphorus.

Clear Creek at Golden, Colorado, and Cache la Poudre River at mouth of canyon, near Fort Collins, Colorado, are similar because both are forest sites. Although mean streamflow during the study period (table 2) was about 1.5 times larger at the Cache la Poudre site than at the Clear Creek site, loads were larger at the Clear Creek site than at the Cache la Poudre site, particularly for total phosphorus (26 tons and 6 tons, respectively) and for suspended sediment (79,000 tons and 10,000 tons respectively). This comparison illustrates the large differences in water quality, which may be due to small differences in land use. The Clear Creek site has 3.1 percent urban land use (fig. 5) whereas the Cache la Poudre site has 0.3 percent urban land use (fig. 9). The Clear Creek site also is affected by mining development, which is indicated by the relatively large proportion of barren land (1.1 percent) in the basin.

South Platte River near Kersey, Colorado, and St. Vrain Creek at mouth, near Platteville, Colorado, are similar because both sites are Integrator Sites affected by urban and agricultural land use. Mean streamflow during the study period (table 2) was about 4 times larger at the South Platte River site than at the St. Vrain Creek site. Loads at the South Platte River site were similarly larger than at the St. Vrain site for dissolved solids (about 4.8 times larger), total nitrogen (about 5.8 times larger), total phosphorus (about 5.2 times larger), and suspended sediment ( 3.0 times larger). This comparison indicated that mixed urban/agricultural land use produced proportionately similar water quality in streams of quite different sizes.

For three sites along the South Platte River, daily loads for total nitrogen and suspended sediment were summed by month to examine the seasonal variability in loads. Monthly total-nitrogen loads (fig. 22) were fairly constant during 1993 and 1994 at the fixed site at Denver, Colorado. Much of the nitrogen at this 


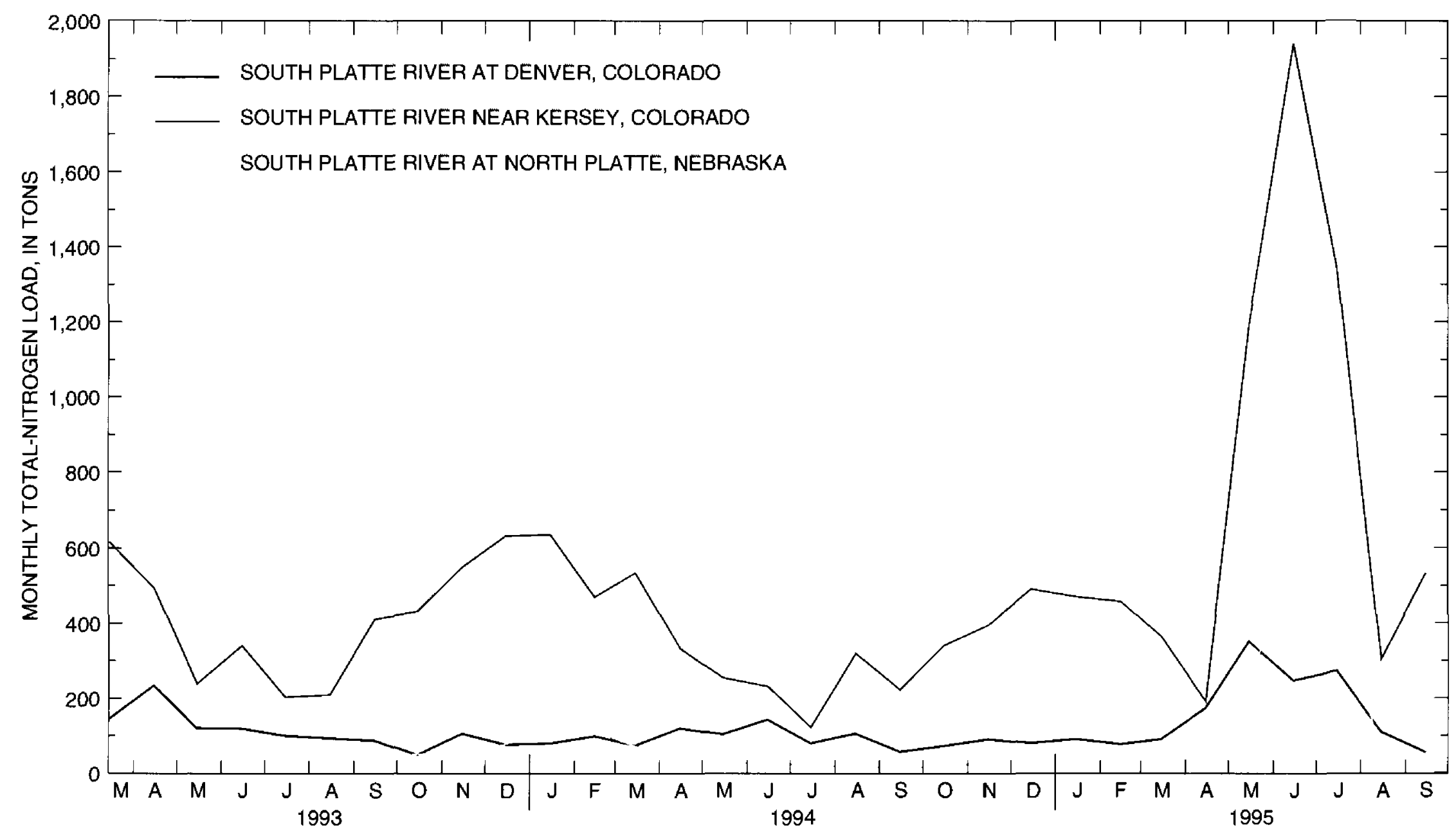

Figure 22. Monthly total-nitrogen loads at three fixed sites along the South Platte River, May 1993 through September 1995.

site is derived from the year-round discharges from wastewater-treatment plants. During 1993 and 1994, nitrogen loads at the site at North Platte and especially at the site near Kersey, Colorado (fig. 22), had a seasonal pattern similar to the seasonal pattern of streamflow at those sites (figs. 12 and 14), with streamflow and loads largest during the winter. This indicates that loads are largest when irrigation ditches do not remove upstream water from the river. During the May-July 1995 rainfall-runoff event, nitrogen loads increased substantially at all three sites. Totalnitrogen loads during these 3 months accounted for an average of 37 percent of the total-nitrogen load during the entire 31-month study period at the fixed sites along the South Platte River. The increase in load, however, was substantially smaller than the increase in streamflow at these sites during the runoff event, which indicates that rainfall runoff may have contributed some additional nitrogen load to the river, but some of the load increase might be attributed to ditches closing during the event and allowing urban nitrogen loads to pass downstream. Monthly load estimates for dissolved solids indicated that loads during May-July 1995 accounted for an average of 40 percent of the total dissolved-solids load during the entire 31-month study period at sites along the South Platte River, and load estimates for total phosphorus indicated that 50 percent of the total load occurred during this period. These larger percentages indicated that rainfall-runoff contributions are larger for dissolved solids and total phosphorus than for nitrogen.

In contrast to total-nitrogen loads, monthly suspended-sediment loads (fig. 23) generally were largest during runoff events and small at other times, which indicated that the principal sources of suspended sediment were overland runoff and the channel erosion that occurs during runoff events. Suspended-sediment loads at the fixed site at Denver, Colorado, were larger during 1994 than during 1993, perhaps due to construction in the channel during 1994. Suspended-sediment loads during the May-July 1995 rainfall-runoff event accounted for an average of 83 percent of the total suspended-sediment load during the entire 31-month study period at sites along the South Platte River. This percentage is the largest among the four constituents examined, which also indicated the importance of runoff events as sources of suspended sediment. 


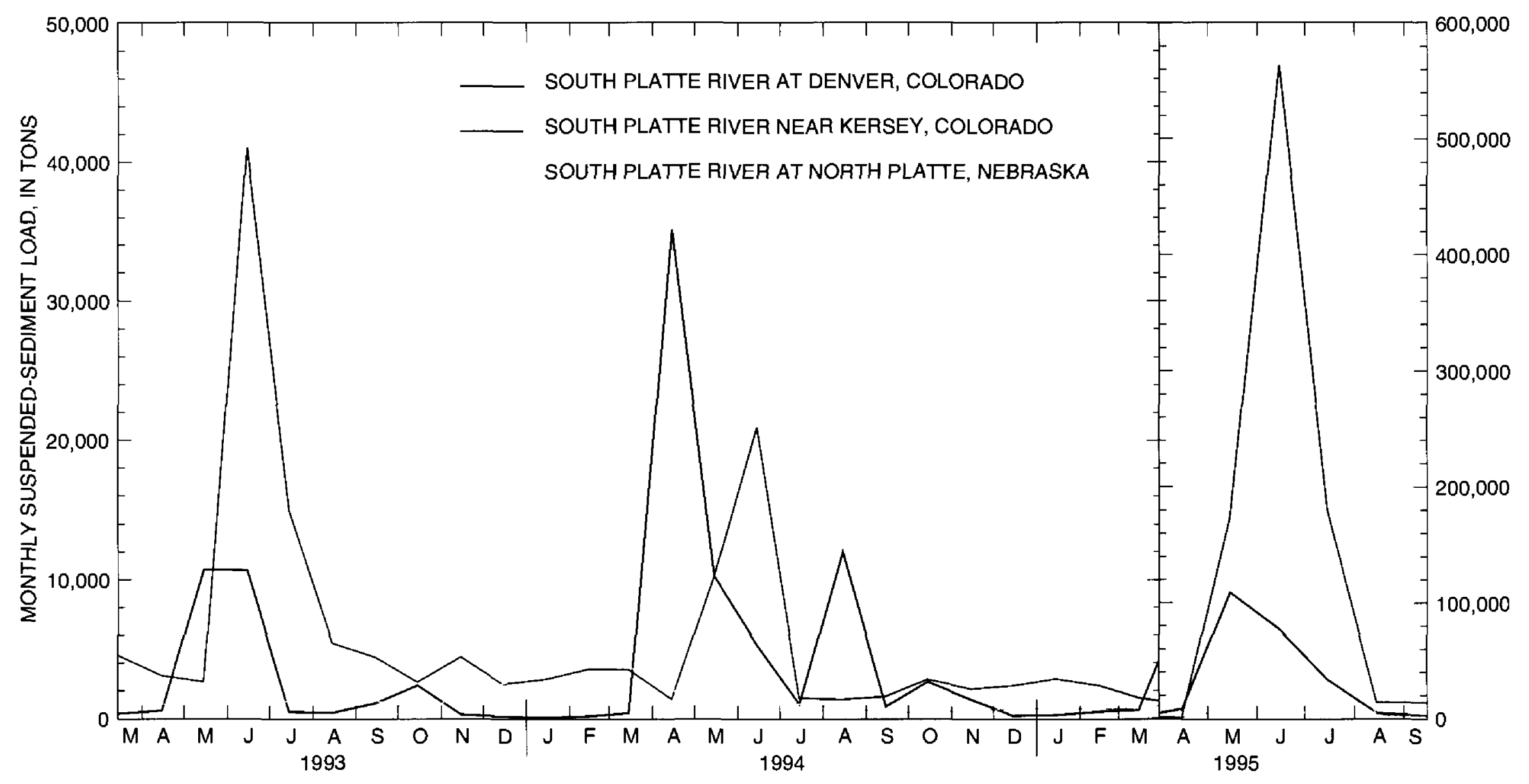

Figure 23. Monthly suspended-sediment loads at three fixed sites along the South Platte River, May 1993 through September 1995.

\section{SUMMARY}

In 1991, the U.S. Geological Survey (USGS) began full-scale implementation of the National Water-Quality Assessment (NAWQA) Program, with the objectives of describing the status and trends in the quality of a large, representative part of the Nation's surface- and ground-water resources and of providing a sound scientific understanding of the primary natural and human factors affecting the quality of these resources. The South Platte River Basin was among the first 20 NAWQA study units selected for study under the full-scale implementation plan. TweIve fixed sites were sampled from March 1993 to September 1995 as part of the NAWQA study. Constituents determined from monthly sampling incIude field measurements and concentrations of major constituents, organic carbon, nutrients, and suspended sediment. This report describes the environmental setting at the sites, summarizes water-quality concentration data, discusses the effects of land use on concentrations, evaluates historicaI trends in concentrations at selected sites, and presents estimates of stream loads for selected constituents.

Fixed sites are an integral element in the surface-water design of the NAWQA Program. There are two types of fixed sites. Integrator Sites are chosen to represent water-quality conditions of rivers in heterogenous large basins that are affected by complex combinations of environmental settings. For the South Platte River Basin, two Integrator Sites were selected that represent mixed urban/agricultural land use. Indicator Sites are chosen to represent water-quality conditions of streams in relatively homogenous areas. Four predominant environments exist in the South PIatte River Basin as determined by a stratification scheme using physiographic province, geology, and land use; one stratum predominates for each of the four major Iand uses that occur in the basin. Three Indicator Sites were selected to represent the agricultural land-use stratum; three sites to represent the urban Iand-use stratum; three sites to represent the forest land use stratum; and one site to represent the rangeland-use stratum.

Major anthropogenic features that occur upstream from the fixed sites and might affect water quality at the sites include wastewater-treatment-plant discharges, transmountain water imports, water diversions, rural development, mining, and agricultural features such as cropland and feedlots. In the South Platte River Basin, as in other parts of the arid West, water can be routed through a variety of artificial 
structures to meet water demands of cities and agricultural users. As a result, the contributing sources of water at a fixed site can vary daily, with each source being affected by different land uses, and characterization of the land use at a site requires information about the various water sources. Because water is removed from the river all along its length, water at a site often is derived more from local sources than from upstream sources, resulting in local land use being more important than land use in the entire basin. Water discharge from the alluvial aquifer to the river is important at many sites because the aquifer is recharged by irrigation return flows. Climate conditions varied during the study period; the first 2 years of the study were dry years, and streamflow at the sites was smaller than the long-term (1976-95) mean (69 percent of the mean during water year 1993 and 56 percent of the mean during 1994). The last year of the study included an unusually large snowmelt-runoff peak that was supplemented by large amounts of spring rainfall, which resulted in higher than normal streamflow (180 percent of the long-term mean during 1995).

Water-quality samples were collected at each fixed site during March 1993 to September 1995 as part of regular monthly sampling or sampling of runoff events. Data from quality-assurance sampling (33 blank samples and 31 pairs of replicate samples) indicated that results were accurate and precise. Concentration data were compared to stream standards as points of reference for water quality. There were occasional occurrences of constituent concentrations exceeding chronic stream-segment standards for sulfate (one exceedance at an urban site), iron (one at a forest site), nitrite (one at an urban site), and unionized ammonia (three exceedances at urban sites). However, there were more common exceedances of chronic standards for manganese at one forest site, two urban sites, and one Integrator Site. The USEPA recommended limit for total phosphorus concentrations in streams $(0.1 \mathrm{mg} / \mathrm{L})$ for the control of eutrophication was exceeded at all urban, agricultural, and mixed urban/agricultural site, and at one forest site; the minimum measured phosphorus concentration exceeded the recommended limit at most of these sites.

Boxplots of principal water-quality constituents indicated differences in the distribution of concentration data among the sites. Statistical tests (KruskalWallis and Tukey's multiple comparison) detected significant differences in median values between sites.
Median water temperatures were highest at urban sites. Specific conductance ard dissolved-solids concentrations were largest at two sites representing agricultural land use and smallest at the three sites representing forest land use. Median specific conductance increased in the South Platte River in a downstream direction from Denver, Colorado, to Balzac, Colorado, and then decreased between Balzac and North Platte, Nebraska. Calcium and sulfate were the predominant ions in water at agricultural sites. Water from urban sites had more sodium plus potassium and chloride than water from agricultural sites. Calcium and bicarbonate predominated at the forested sites (except the Clear Creek site) and the rangeland site. Concentrations of iron plus manganese generally were largest at forest and urban sites and smallest at agricultural sites, but variation in land uses was large. Total nitrogen concentrations were large in urban, mixed urban/agricultural, and agricultural land uses and small in forest and rangeland use. Suspended-sediment concentrations were largest for sites in agricultural and mixed urban/agricultural land use and smallest for sites in forest land use.

The NAWQA hypothesis that water quality is different for different land uses was tested by combining data for fixed sites according to land use and then testing for significant differences. Land use was a statistically significant classifying variable for all of the water-quality constituents. For some constituents (specific conductance, water temperature, dissolved solids, and sodium), each land use was significantly different from all others. For other constituents (for example, nitrite plus nitrate), there were as few as two significant groupings.

Water quality generally was best (significantly smaller median concentrations) for rangeland and forest land use. Although forest land use generally formed a unique water-quality group, substantial differences in concentrations occurred within the forest land use that were attributed to differences in the magnitude of wastewater-treatment-plant discharges and mining land use upstream from the three forest land-use fixed sites and to differences in the level of development.

Urban land use had the largest median concentrations or values (or was tied for the largest concentrations or values) for 16 constituents, but only water temperature was uniquely largest in urban land use; generally urban land use was not significantly different from mixed urban/agricultural land use. Most 
of the variability within urban land use was attributed to the magnitude of inputs from wastewater-treatment plants upstream from the three urban land-use fixed sites.

Agricultural land use had the largest median concentrations or values (or was tied for the largest concentrations or values) for 17 constituents. Agricultural land use was a unique group for 10 constituents and had the largest median concentrations or values for 7 of these constituents ( $\mathrm{pH}$, specific conductance, dissolved solids, calcium, potassium, sodium, and sulfate). Agricultural land use was tied with mixed urban/agricultural land use for the largest concentrations of suspended sediment, and because urban land use had smaller concentrations, agricultural land use was assumed to be the primary source of suspended sediment. There was substantial variability in constituent concentrations within agricultural land use. This variability was attributed to differing proportions of water sources at the three agricultural sites.

Mixed urban/agricultural land use had the poorest water quality (greatest number of large median concentrations) among the land uses sampled, which was attributed to the combined effects of urban and agricultural land use. Variability of concentrations within this land use was small, which indicated that the integration of combined land uses produces similar water quality in medium- and large-sized basins.

Historical concentration data (1963-96) from USGS and USEPA data bases for fixed sites along the South Platte River were analyzed for trends using the seasonal Kendall test. The results indicated downward trends in salinity at sites along the South Platte River, whereas nitrate concentrations had upward trends. Streamflow had upward trends at sites along the river, but the salinity and nitrate concentration trends still were significant after being adjusted for variability in streamflow.

Daily loads were estimated at the fixed sites for dissolved solids, total nitrogen, total phosphorus, and suspended sediment for March 1993 to September 1995. Among the sites, loads were largest at South Platte River near Kersey, Colorado, where streamflow also was largest; mean annual loads at this site for water years 1994-95 were 810,000 tons of dissolved solids, 510,000 tons of suspended sediment, 880 tons of total phosphorus, and 6,400 tons of total nitrogen. The downstream pattern of mean annual loads along the South Platte River was similar for the four constituents; loads increased from Denver to Kersey, Colo- rado, and decreased from Kersey to North Platte, Nebraska. Between Kersey and North Platte, totalnitrogen and total-phosphorus loads decreased by a factor of about 5, whereas dissolved-solids loads only decreased by a factor of 1.4. This difference was attributed to smaller local inputs of nitrogen and phosphorus in this segment compared to inputs for dissolved solids.

\section{REFERENCES CITED}

Camp Dresser \& McKee, Inc., 1993, Physical habitat composition as it relates to fish of segment 15: Denver, Metro Wastewater Reclamation District, variously paged.

Colorado Department of Health, 1993a, Classifications and numeric standards for the South Platte River Basin, Laramie River Basin, Republican River Basin, and Smoky Hill River Basin 3.8.0: Denver, Water Quality Control Commission 5 CCR 1002-8, 148 p.

Colorado Department of Health, 1993b, The basic standards and methodologies for surface water 3.1.0: Denver, Water Quality Control Commission 5 CCR 1002-8, $131 \mathrm{p}$.

Conover, W.J., and Iman, R.L., 1981, Rank transformation as a bridge between parametric and nonparametric statistics: American Statistician, v. 35, no. 3, p. $124-129$.

Crowfoot, R.M., Ugland, R.C., Maura, W.S., Steger, R.D., and O'Neill, G.B., 1996, Water resources data, Colorado, water year 1995, v. 1, Missouri River Basin, Arkansas River Basin, and Rio Grande Basin: U.S. Geological Survey Water-Data Report CO-95-1, $506 \mathrm{p}$.

Dennehy, K.F., 1991, National Water-Quality Assessment Program-South Platte River Basin: U.S. Geological Survey Open-File Report 91-155, 2 p. [Water fact sheet.]

Dennehy, K.F., Litke, D.W., McMahon, P.B., Heiny, J.S., and Tate, C.M., 1995, Water-quality assessment of the South Platte River Basin, Colorado, Nebraska, and Wyoming-Analysis of available nutrient, suspendedsediment, and pesticide data, water years 1980-92: U.S. Geological Survey Water-Resources Investigations Report 94-4095, 145 p.

Dennehy, K.F., Litke, D.W., Tate, C.M., and Heiny, J.S., 1993, South Platte River Basin-Colorado, Nebraska, and Wyoming: Water Resources Bulletin, v. 28, no. 4, p. $647-683$. 
DuBois, David, 1985, Area-wide water quality management plan for the Larimer-Weld region-1985 update:

Loveland, Colo., Larimer-Weld Regional Council of Governments, variously paged.

Edwards, T.K., and Glysson, G.D., 1988, Field methods for measurement of fluvial sediment: U.S. Geological Survey Open-File Report 86-531, 118 p.

Fegeas, R.G., Claire, R.W., Guptill, S.C., Anderson, K.E., and Hallam, C.A., 1983, Land use and land cover digital data: U.S. Geological Survey Circular 895-E, $21 \mathrm{p}$.

Ficklin, W.H., and Smith, K.S., 1994, Influence of mine drainage on Clear Creek, Colorado, in Stewart, K.C., and Severson, R.C., eds., Guidebook on the geology, history, and surface-water contamination and remediation in the area from Denver to Idaho Springs, Colorado: U.S. Geological Survey Circular 1097, p. 43-48.

Fishman, M.J., ed., 1993, Methods of analysis by the U.S. Geological Survey National Water Quality Laboratory-Determination of inorganic and organic constituents in water and fluvial sediments: U.S. Geological Survey Open-File Report 93-125, 217 p.

Fishman, M.J., and Friedman, L.C., eds., 1989, Methods for determination of inorganic substances in water and fluvial sediments: U.S. Geological Survey Techniques of Water-Resources Investigations, book 5, chap. A1, 545 p.

Gilliom, R.J., Alley, W.M., and Gurtz, M.E., 1995, Design of the National Water-Quality Assessment ProgramOccurrence and distribution of water-quality conditions: U.S. Geological Survey Circular 1112, 33 p.

Guy, H.P., and Norman, V.W., 1982, Field methods for measurement of fluvial sediment: U.S. Geological Survey Techniques of Water-Resources Investigations, book 3 , chap. C2, 59 p. [Fourth printing.]

Heiny, J.S., and Tate, C.M., 1997, Concentration, distribution, and comparison of selected trace elements in bed sediment and fish tissue in the South Platte River Basin, USA, 1992-1993: Archives of Environmental Contamination and Toxicology. v. 32, p. 246-259.

Helsel, D.R., and Hirsch, R.M., 1992, Statistical methods in water resources: Amsterdam, Elsevier, $522 \mathrm{p}$.

Hem, J.D., 1985, Study and interpretation of the chemical characteristics of natural water ( $3 \mathrm{~d}$ ed.): U.S. Geological Survey Water-Supply Paper 2254, 263 p.

Iman, R.L., and Conover, W.J., 1983, A modern approach to statistics: New York, Wiley, 497 p.

Leahy, P.P., Rosenshein, J.S., and Knopman, D.S., 1990, Implementation plan for the National Water-Quality Assessment Program: U.S. Geological Survey OpenFile Report 90-174, 10 p.
Litke, D.W., 1996, Sources and loads of nutrients in the South Platte River, Colorado and Nebraska, 1994-95: U.S. Geological Survey Water-Resources Investigations Report 96-4029, 31 p.

Meador, M.R., Hupp, C.R., Cuffney, T.F., and Gurtz, M.E., 1993, Methods for characterizing stream habitat as part of the National Water-Quality Assessment Program: U.S. Geological Survey Open-File Report 93-408, $48 \mathrm{p}$.

Nebraska Department of Environmental Quality, 1996, Nebraska surface water quality standards: Lincoln, Nebr., Department of Environmental Quality, Title 117 , variously paged.

Patton, C.J., and Truitt, E.P., 1992, Methods of analysis by the U.S. Geological Survey National Water Quality Laboratory-Determination of total phosphorus by a Kjeldahl digestion method and an automated colorimetric finish that includes dialysis: U.S. Geological Survey Open-File Report 92-146, 39 p.

Piper, A.M., 1944, A graphic procedure in the geochemical interpretation of water analyses: American Geophysical Union Transactions, v. 25, p. 914-923.

Qi, S.L., and Dennehy, K.F., 1997, World Wide Web home page for the South Platte NAWQA: U.S. Geological Survey Fact Sheet FS-242-96, 1 p.

Rodrigo, Mark, 1994, Land use/cover classification of remotely sensed imagery and conversion to a vector based GIS for the Denver metro area: Denver, University of Denver, Master's thesis.

Schertz, T.L., Alexander, R.B., and Ohe, D.J., 1991, The computer program EStimate TREND (ESTREND), a system for the detection of trends in water-quality data: U.S. Geological Survey Water-Resources Investigations Report 91-4040, 63 p.

Shelton, L.R., 1994, Field guide for collecting and processing stream-water samples for the National Water-Quality Assessment Program: U.S. Geological Survey Open-File Report 94-455, 42 p.

Tate, C.M., and Heiny, J.S., 1995, The ordination of benthic invertebrate communities in the South Platte River Basin in relation to environmental factors: Freshwater Biology, v. 33, no. 3, p. 439-454.

Tate, C.M., and Heiny, J.S., 1996, Organochlorine compounds in bed sediment and fish tissue in the South Platte River Basin, USA, 1992-1993: Archives of Environmental Contamination and Toxicology, v. 30, no. 1, p. 62-78.

Ugland, R.C., Cochran, B.J., Hiner, M.M., and Steger, R.D., 1994, Water resources data, Colorado, water year 1993, v. 1, Missouri River Basin, Arkansas River Basin, and Rio Grande Basin: U.S. Geological Survey Water-Data Report CO-93-1, 518 p. 
Ugland, R.C., Maura, W.S., Steger, R.D., and O'Neill, G.B., 1995, Water resources data, Colorado, water year 1994, v. 1, Missouri River Basin, Arkansas River Basin, and Rio Grande Basin: U.S. Geological Survey Water-Data Report CO-94-1, 418 p.

U.S. Environmental Protection Agency, 1986, Quality criteria for water, 1986: U.S. Environmental Protection Agency Report 440/5-86-001, [variously paged]. 1990, Maximum contaminant levels (subpart B of 141 , National primary drinking water regulations) (revised July 1, 1990): U.S. Code of Federal Regulations, Title 40, Parts 100-149, p. 559-563.
1996, Drinking water regulations and health advisories: U.S. Environmental Protection Agency Office of Water Report 822-B-96-002, 16 p.

Wagner, D.G., 1992, Integrating remote sensing and ecological modeling for assessing terrestrial ecosystems-Report to the U.S. Geological Survey under contract 14-08-0001-A074: Fort Collins, Colorado State University.

Wentz, D.A., 1974, Environment of the middle segment, Cache la Poudre River, Colorado: Denver, Colorado Division of Wildlife, $38 \mathrm{p}$. 